\title{
Enkele aspecten van de circulatie bij het chronisch obstructief longlijden
}

Citation for published version (APA):

Dees, A. (1992). Enkele aspecten van de circulatie bij het chronisch obstructief longlijden. [Doctoral Thesis, Maastricht University]. Rijksuniversiteit Limburg. https://doi.org/10.26481/dis.19920604ad

Document status and date:

Published: 01/01/1992

DOI:

10.26481/dis.19920604ad

Document Version:

Publisher's PDF, also known as Version of record

\section{Please check the document version of this publication:}

- A submitted manuscript is the version of the article upon submission and before peer-review. There can be important differences between the submitted version and the official published version of record.

People interested in the research are advised to contact the author for the final version of the publication, or visit the DOI to the publisher's website.

- The final author version and the galley proof are versions of the publication after peer review.

- The final published version features the final layout of the paper including the volume, issue and page numbers.

Link to publication

\footnotetext{
General rights rights.

- You may freely distribute the URL identifying the publication in the public portal. please follow below link for the End User Agreement:

www.umlib.nl/taverne-license

Take down policy

If you believe that this document breaches copyright please contact us at:

repository@maastrichtuniversity.nl

providing details and we will investigate your claim.
}

Copyright and moral rights for the publications made accessible in the public portal are retained by the authors and/or other copyright owners and it is a condition of accessing publications that users recognise and abide by the legal requirements associated with these

- Users may download and print one copy of any publication from the public portal for the purpose of private study or research.

- You may not further distribute the material or use it for any profit-making activity or commercial gain

If the publication is distributed under the terms of Article $25 \mathrm{fa}$ of the Dutch Copyright Act, indicated by the "Taverne" license above, 


\section{Enkele aspecten van de circulatie bij het chronisch obstructief longlijden}

A. Dees 
CIP-GEGEVENS KONINKLIJKE BIBLIOTHEEK, DEN HAAG

Dees, A.

Enkele aspecten wan de circulatie bij het chronisch obstructief longlijden / A. Dees; [ill. C. Hubers van Assenraad]. - [S.I. : s.n.]. - Ill.

Proefschrift Maastricht. - Met lit. opg. ISBN 90-9005071-X

Trefw.: longziekten / bloedsomloop

Copyright 1992 Adrian Dees.

Alle rechten voorbehouden. Niets uit deze uitgave mag worden verveelvoudigd, opgeslagen in een geautomatiseerd gegevensbestand, of openbaar gemaakt in enige vorm of op enige wijze, hetzij elektronisch, mechanisch, door fotokopieën, opnamen of op enige andere manier, zondler voorafgaande schriftelijke toestemming van de auteur. 


\section{ENKELE ASPECTEN VAN DE CIRCULATIE BIJ HET CHRONISCH OBSTRUCTIEF LONGLIJDEN}

Circulatory aspects of chronic obstructive pulmonary disease

\section{PROEFSCHRIFT}

ter verkrijging van de graad van doctor

aan de Rijksuniversiteit Limburg te Maastricht, op gezag van de Rector Magnificus, Prof. Mr. M.J. Cohen, volgens besluit van het College van Dekanen, in het openbaar te verdedigen op donderdag 4 juni 1992 om 14:00 uur

door

\section{Adriaan Dees}

geboren te Terneuzen 
Promotores

: Prof. dr. P.W. de Leeuw

Prof. dr. W.H. Birkenhäger (Erasmus Universiteit Rotterdam)

Beoordelingscommissie : Prof. dr. S.C.M. Luijendijk (voorzitter)

Dr, F.W.H.M. Băr

Prof, dr. R. Fagard (Katholieke Universiteit Leuven)

Prof, dr. J.A. Flendrig

Prof. dr. H.A.J. Struijker Boudier

De totstandkoming en verschijning van dit proefschrift werd mede mogelijk gemaakt door Barendregt \& Partners, ICI-Farma, Merck Sharp \& Dohme BV, Pfizer BV en Sandoz BV. 
"..... en overigens, mijn zoon, wees gewaarschuwd; er is geen einde aan het maken van boeken en veel doorvorsen is afmatting voor het lichaam."

Prediker 12:12

Aan : Nettie en de kinderen, mijn ouders. 


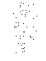

8

B.

$\because \therefore \quad \cdots$ 


\section{Inhoudsopgave}

Verklaring van gebruikte afkortingen

2 Literatuuroverzicht pulmonale hypertensie $\ldots \ldots \ldots \ldots \ldots \ldots \ldots$

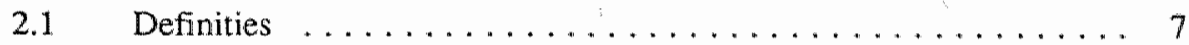

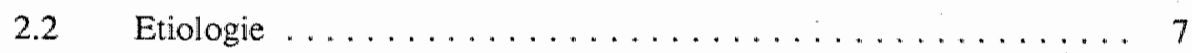

2.3 Pathofysiologie $\ldots \ldots \ldots \ldots \ldots \ldots \ldots \ldots \ldots \ldots \ldots$

2.4 Pathofysiologische effecten van hypercapnie en hypoxie . . . . . 10

2.4.1 Effecten op het sympatische zenuwstelsel ........ 11

2.4.2 Effecten op het renine-angiotensine-aldosteron systeem en de nieren . . . . . . . . . . . . . . 12

2.4.3 De plaats van het atriaal natriuretisch peptide (ANP) $\ldots 13$

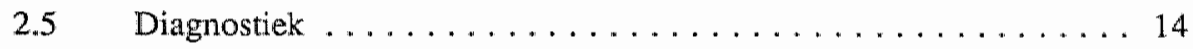

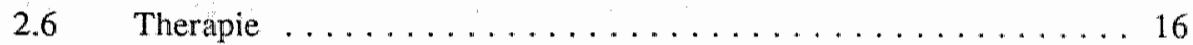

2.6.1 Digitalis en diuretica $\ldots \ldots \ldots \ldots \ldots \ldots \ldots \ldots \ldots$

2.6.2 Het gebruik van vaatverwijders bij de behandeling van pulmonale hypertensie . . . . . . . . . . . . . 17

2.6.3 Het gebruik van onderhoudstherapie met zuurstof . . . . . 19

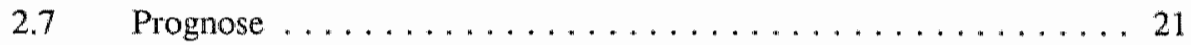

3 Patiënten en Methoden $\ldots \ldots \ldots \ldots \ldots \ldots \ldots \ldots \ldots \ldots \ldots \ldots . \ldots \ldots$

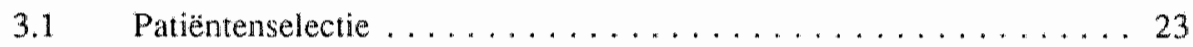

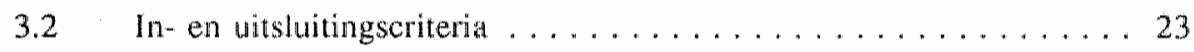

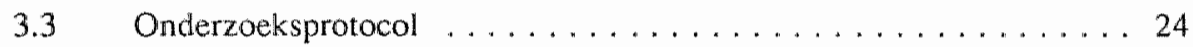

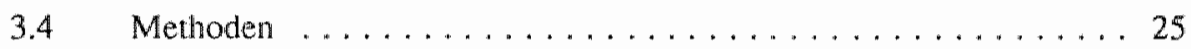

3.5 Specifieke laboratoriumbepalingen $\ldots \ldots \ldots \ldots \ldots \ldots \ldots 27$

3.5.1 Catecholamines (noradrenaline, adrenaline, dopamine) . . . 28

3.5.2 Actieve plasma-renineconcentratie (APRC) . . . . . . . 29

3.5.3 Angiotensine II . . . . . . . . . . . . . . . . . 29

3.5.4 Aldosteron . . . . . . . . . . . . . . . . . . . . 29

3.5.5 Angiotensine converting enzyme $\ldots \ldots \ldots \ldots \ldots \ldots$ 
3.5.6 Atriaal natriuretisch peptide $\ldots \ldots \ldots \ldots \ldots \ldots \ldots \ldots \ldots$

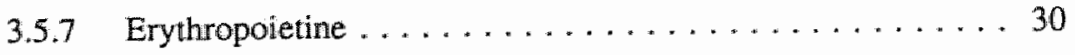

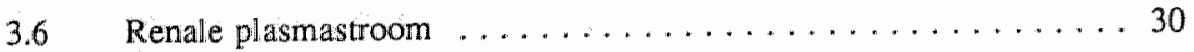

3.7 Statistische methoden $\ldots \ldots \ldots \ldots \ldots \ldots \ldots \ldots \ldots \ldots . \ldots . \ldots . \ldots$

4 Resultaten van het onderzoek ................... 33

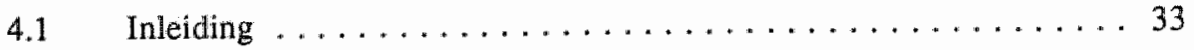

4.2 Gegevens met betrekking tot de circulatie ............. 34

4.2 .1 Uitgangswaarden $\ldots \ldots \ldots \ldots \ldots \ldots \ldots \ldots \ldots \ldots \ldots \ldots$

4.2 .2 Verbanden $\ldots \ldots \ldots \ldots \ldots \ldots \ldots \ldots \ldots \ldots \ldots \ldots . \ldots \ldots$

4.3 Gegevens met betrekking tot de gaswisseling .......... 40

4.4 Relaties tussen de circulatoire en respiratoire variabelen . . . . . . 4 41

4.4.1 Longfunctie en haemodynamiek . . . . . . . . . . . 41

4.4 .2 Gaswaarden en haemodynamiek ............. 42

$4.5 \quad$ Neuro-endocriene activiteit $\ldots \ldots \ldots \ldots \ldots \ldots \ldots \ldots . \ldots . \ldots 47$

4.5.1 Neuro-endocriene gegevens en gaswaarden . . . . . . . 47

4.5.2 Neuro-endocriene activiteit en longfunctie . . . . . . . . 48

4.6 Subgroepanalyse en voorspelling van de gemiddelde arteria pulmonalisdruk (mPAP) $\ldots \ldots \ldots \ldots \ldots \ldots \ldots \ldots \ldots$

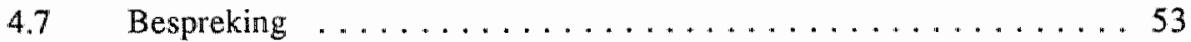

$5 \quad$ Effecten van nifedipine, vergeleken met die van placebo . . . . . . . . 59

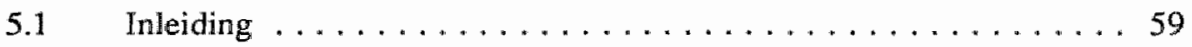

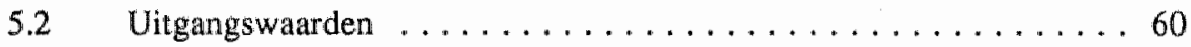

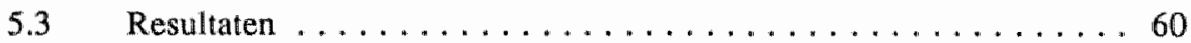

5.3.1 Systemische effecten van nifedipine $\ldots \ldots \ldots \ldots \ldots 61$

5.3.2 Pulmonale effecten van nifedipine $\ldots \ldots \ldots \ldots \ldots 64$

5.3.3 Invloed van nifedipine op de gaswaarden $\ldots \ldots \ldots \ldots 64$

5.3.4 Betekenis van pulmonale hypertensie of hypercapnie voor de reactie op nifedipine $\ldots \ldots \ldots \ldots \ldots \ldots 6$

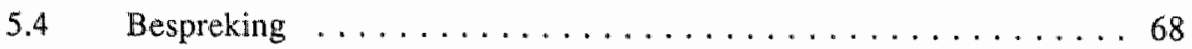

$6 \quad$ Nifedipine versus captopril $\ldots \ldots \ldots \ldots \ldots \ldots \ldots \ldots \ldots \ldots \ldots$

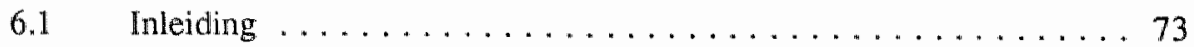

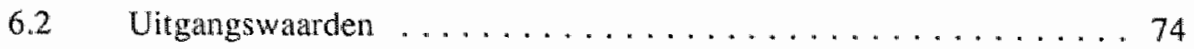


6.3 Effecten van nifedipine en captopril $\ldots \ldots \ldots \ldots \ldots \ldots$

6.3 .1 Haemodynamiek . . . . . . . . . . . . . . . . . 76

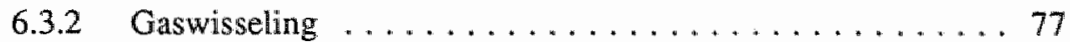

6.3 .3 Hormoonwaarden . . . . . . . . . . . . . . . 79

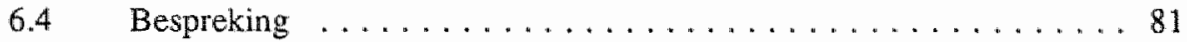

$7 \quad$ De overleving van de patiënten $\ldots \ldots \ldots \ldots \ldots \ldots \ldots \ldots \ldots$

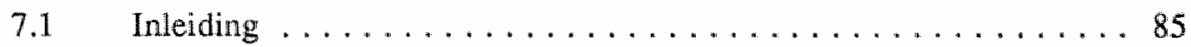

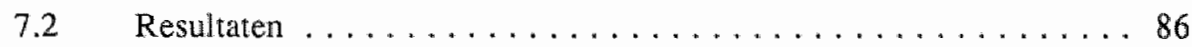

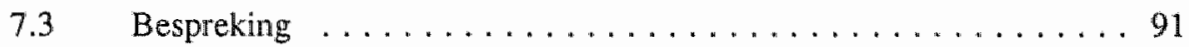

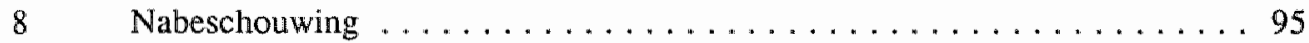

$8.1 \quad$ Methodologische aspecten $\ldots \ldots \ldots \ldots \ldots \ldots \ldots \ldots \ldots$

8.2 Haemodynamische aspecten van het cor pulmonale . . . . . . . 96

8.3 De arteriële bloeddruk en het cor pulmonale . . . . . . . . . . . 99

8.4 Het sympatisch zenuwstelsel en het pulmonale vaatbed ....... 101

8.5 Het veneuze vaatbed $\ldots \ldots \ldots \ldots \ldots \ldots \ldots \ldots \ldots \ldots \ldots$

8.6 Therapeutische aspecten $\ldots \ldots \ldots \ldots \ldots \ldots \ldots \ldots \ldots \ldots$

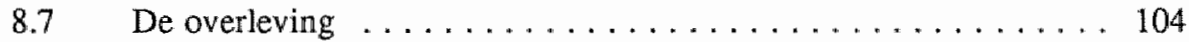

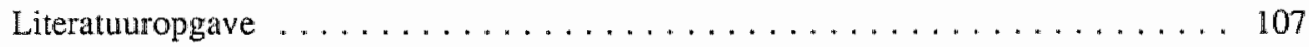

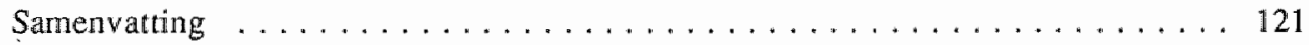

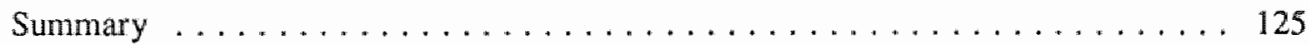

Dankwoord ... . . . . . . . . . . . . . . . . . . . . . . . . . . 127

Curriculum vitae . . . . . . . . . . . . . . . . . . . . . . . . . . . . 129

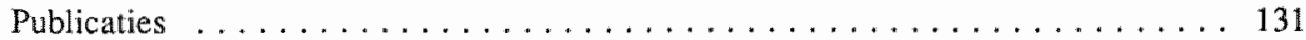


$\therefore \quad$

$\therefore$ 


\section{Verklaring van gebruikte afkortingen}

ACE : Angiotensine I Converting Enzyme

ANP : Atriaal Natriuretisch Peptide

APRC : Actieve Plasma Renine Concentratie

A II : Angiotensine II

BSA : Lichaamsoppervlak

$\mathrm{CaO}_{2}$ : Arteriële zuurstofhoeveelheid

$\mathrm{CcO}_{2}$ : Capillaire zuurstofhoeveelheid

CI : Hartminuutvolume-index

$\mathrm{CO}$ : Hartminuutvolume

$\mathrm{CrO}_{2}$ : Veneuze zuurstofhoeveelheid

DP : Perfusiegradiènt in het longvaatbed

EPO : Erythropoietine

$\mathrm{FEV}_{1} \quad$ : Geforceerde expiratoire én-seconde waarde

FVC : Geforceerde vitale capaciteit

$\mathrm{Hb}$ : Hemoglobine

HF : Hartfrequentie

$\mathrm{Ht}$ : Hematocriet

LTOT : Long term oxygen therapy

LVSWI : Arbeidsindex van de linker ventrikel

MAP : Gemiddelde arteriële bloeddruk

mPAP : Gemiddelde pulmonale arteriële bloeddruk

MRCWP : Medical Research Council Working Party

NOTT : Nocturnal Oxygen Therapy Trial

OZT : Onderhoudsbehandeling met zuurstof in de thuissituatie

$\mathrm{PaCO}_{2}$ : Arteriële koolzuurspanning

$\mathrm{PaO}_{2} \quad$ : Arteriële zuurstofspanning

PVWP : Capillaire wiggedruk

$\mathrm{PvO}_{2} \quad$ : Gemengd-veneuze zuurstofspanning

PVR : Longvaatweerstand

RAAS : Renine Angiotensine Aldosteron System

RAP : Rechter-atriumdruk

RBF : Renale bloedstroom 


$\begin{array}{ll}\mathrm{RPF} & : \text { Renale plasmastroom } \\ \mathrm{RVR} & : \text { Renale vaatweerstand } \\ \mathrm{RVSWI} & : \text { Arbeidsindex van de rechter ventrikel } \\ \mathrm{SaO}_{2} & : \text { Arteriële zuurstofverzadiging } \\ \mathrm{SOT} & : \text { Systemisch zuurstoftransport } \\ \mathrm{SV} & : \text { Slagvolume } \\ \mathrm{SVI} & : \text { Slagvolume-index } \\ \mathrm{SvO} & : \text { Gemengd-veneuze zuurstofverzadiging } \\ \mathrm{SVR} & : \text { Systemische vaatweerstand } \\ \mathrm{VD}_{2} \mathrm{VT} & : \text { Verhouding tussen dode ruimte en teugvolume } \\ \mathrm{VO}_{2} & : \text { Systemisch zuurstofverbruik }\end{array}$

Voor de gebruikte formules en eenheden wordt verwezen naar hoofdstuk 3. 
Het cor pulmonale ten gevolge van chronisch obstructief longlijden is een ernstige aandoening. Zonder adequate behandeling, zoals door middel van zuurstoftoediening thuis, bedraagt de overleving slechts $30 \%$ na 5 jaar [Bardsley en Howard 1986]. Wanneer onderhoudstoediening met zuurstof gestart wordt, lijkt de prognose vooral bepaald te worden door de ernst en de mate van reversibiliteit van de pulmonale hypertensie [Ashutosh en Dunsky 1987, Weitzenblum et all 1985].

Het mechanisme waardoor zuurstof de overleving verbetert, is niet volledig duidelijk. Er is discussie over de betekenis van de functie van het rechter ventrikel met betrekking tot de prognose: enerzijds lijkt zuurstof deze functie niet te verbeteren [MacNee et al 1988], anderzijds wordt aan het rechter ventrikel een centrale plaats in het gastransport toegedacht [Morrison 1987]. Volgens de laatste hypothese is pulmonale hypertensie de beperkende factor voor het rechter ventrikel bij het op peil houden van het zuurstoftransport.

De aandacht voor de longcirculatie en het rechter ventrikel bij patiënten met chronisch obstructief longlijden, richtte zich dan ook in eerste instantie op de prognostische betekenis en het beloop van de pulmonale bloeddruk tijdens behandeling Traver et al 1979, Weilzenblum et al 1981, Timms et al 1985]. Later verplaatste de aandacht zich naar de vroegtijdige diagnostiek van de pulmonale hypertensie.

In de afgelopen jaren is $\mathrm{er}$, naast vooruitgang in de niet-invasieve diagnostiek [Bishop en Csukas 1989], een groeiende belangstelling ontstaan voor de algehele en renale haemodynamiek in relatie tot de longcirculatie. Verbanden tussen arteriële en pulmonale hypertensie zijn naar voren gekomen bij de bestudering van het zogenaamde slaap-apneusyndroom [Lund-Johansen en White 1990] en van essentiële hypertensie [Fagard el al 1988].

De relatie tussen long- en niercirculatie kan het duidelijkst geillustreerd worden aan de hand van het gedecompenseerde cor pulmonale. Pathofysiologisch werd het ontstaan van oedeem aanvankelijk verklaard vanuit de veronderstelling dat het rechter ventrikel tekort schiet tegenover een sterke toename van de afterload, de pulmonale vaatweerstand [Fishman 1976]. Toch lijken meer mechanismen betrokken te zijn in de oedeemvorming. In studies met stabiele cor pulmonale-patiënten is gebleken dat de rechter-ventrikelcontractiliteit langdurig normaal blijft [MacNee et al 1988, Schrijen et al 1989], doch dat de nierdoorbloeding achterblijft [Oliver et al 1989]. Hypoxie veroorzaakt een verdere achteruitgang in water- en zoutexcretie en 
speelt ook een rol bij de activering van het renine-angiotensine-aldosteron systeem (RAAS) [Farber en Manfredi 1984, Mannix et al 1990].

Een belangrijke klinische waameming wordt gevormd door het feit dat het oedeem vooral optreedt, wanneer er sprake is van zowel hypoxie als hypercapnie. Deze waarneming doet de vraag rijzen in hoeverre het $\mathrm{CO}_{2}$-gehalte zowel de nierdoorbloeding en zoutretentie als de pulmonale haemodynamiek beínvloedt.

In dit proefschrift wordt de verhouding tussen long-, nier- en lichaamscirculatie bij patiënten met chronisch obstructief longlijden nader bestudeerd. Het onderzoek sluit zo aan bij een langer bestaande traditie van circulatie-onderzoek, vanuit de afdeling Inwendige Geneeskunde in het Zuiderziekenhuis te Rotterdam.

Bij de opzet van de studies is uitgegaan van een zo praktisch mogelijke situatie.

Gezien de bewezen waarde wan onderhoudstherapie met zuurstof thuis (OZT) bij het hypoxisch chronisch obstructief longlijden, is gekozen voor bestudering van de haemodynamiek tijdens normoxie. Met betrekking tot de relatie gaswaarden haemodynamiek kon daardoor speciale aandacht gegeven worden aan de invloed van hypercapnie op de circulatie. Hoewel het nut van vaatverwijders bij het cor pulmonale allerminst bewezen is [Whyte en Flenley 1988], gebruiken veel patiënten deze middelen op andere indicatie (hypertensie, coronair lijden). Bovendien heeft een aantal van deze middelen natriuretische eigenschappen, hetgeen op theoretische gronden belangrijk is bij de behandeling van de pulmonale hypertensie. In onze studie is om deze redenen gekozen voor de evaluatie van de effecten van twee vaatverwijders, te weten een calcium-antagonist en een angiotensine I converting enzyme remmer.

Het doel van het onderzoek was het bestuderen wan pathofysiologische mechanismen die een rol zouden kunnen spelen bij de circulatoire veranderingen die zich voordoen als gevolg van chronisch obstructief longlijden. De hypothese daarbij luidt, dat afwijkingen in longfunctie en gaswaarden niet alleen de pulmonale circulatie beïnvloeden, doch eveneens de algemene en de renale circulatie en langs die weg van belang zijn bij het ontstaan van het klinische beeld van het cor pulmonale. 
Samenvattend vormde aldus de volgende inventarisatie de ruggegraat van het onderzoek bij patiënten met het chronisch obstructief longlijden:

- algemene gegevens als gaswaarden, longfunctie.

- bepalingen van de algemene, pulmonale en renale haemodynamiek.

- bepalingen van catecholaminen en van renine, angiotensine II en aldosteron in plasma. 



\section{Literatuuroverzicht pulmonale hypertensie}

\subsection{Definities}

Met de termen pulmonale hypertensie en cor pulmonale worden in dit proefschrift bedoeld de vormen, welke secundair zijn aan het chronisch obstructief longlijden.

Van pulmonale hypertensie wordt gesproken indien de gemiddelde arteria pulmonalisdruk (mPAP), in rust gemeten, hoger is dan $20 \mathrm{mmHg}$ [Matthay et al 1990].

In tegenstelling tot de pulmonale hypertensie, gedefinieerd in maat en getal, is de definitie van het cor pulmonale tweeledig. Pathologisch-anatomisch kunnen de afwijkingen in het rechter hart, vooral de hypertrofie, nauwkeurig vastgelegd worden, doch klinisch is de definitie beschrijvend en weerspiegelt het de inzichten in de pathofysiologie. De aandacht voor de rechter-ventrikelfunctie spreekt uit de definitie van Fishmann: het cor pulmonale is een rechter-ventrikelfalen, in essentie veroorzaakt door een ziekte welke de structuur en/of functie van de longen, longvaten of thoraxwand aantast, tenzij een primaire aandoening wan de linker harthelft of een congenitale hartafwijking in het spel is [Fishmainn 1976].

Een meer recente definitie verwijst naar de invloed van de gaswisseling op de vochthuishouding en spreekt van chronisch-respiratoir falen, gepaard gaande met periodes van ernstige oedeemvorming [Denolin 1989]. De diverse aspecten van het cor pulmonale komen waarschijnlijk nog het duidelijkst naar voren in de definitie van Hurewitz en Bergofsky: cor pulmonale, ten gevolge van pulmonale hypertensie, is een te kort schieten van het rechter ventrikel om de achteruitgang in gaswisseling en zuurstoftransport op te vangen. Dit is de definitie die ook in dit proefschrift zal worden aangehouden [Hurewitz en Bergotsky 1988].

\subsection{Etiologie}

In de etiologie van pulmonale hypertensie kunnen verschillende aandoeningen betrokken zijn. De oorzaken zijn wel geclassificeerd naar de aard van de vasculaire afwijkingen, anatomisch en/of functioneel [Hurewitz en Bergotsky 1988], zoals samengevat in tabel 2.1. Dikwijls betreft het een combinatie van anatomische en functionele afwijkingen, zoals bij het chronisch obstructief longlijden, de kyphoscoliose en verschillende vormen van interstitiële longziekten. 
Tabel 2.1: Indeling wan oorzaken van pulmonale bypertensie:

A. Anatomisch-mechanische afwijkingen

- Thrombo-embolische ziekten

- Primaire pulmonale hypertensie

- Sclerodermie, Crest-syndroom

- Na uitgebreide longchirurgie

- Emphysema pulmonum

B. Functionele afwijkingen (vasoconstrictie secundair aan abnornale gaswaarden)

Alweolaire hypowentilatie (neuromusculair, slaap-apneu etc.)

Verblyf op grote hoogte

Uitgaande van de functionele afwijkingen wordt chronische hypoxie beschouwd als de belangrijkste oorzaak van pulmonale hypertensie [Von Euler en Liljestrand 1946 Fishman 1976, Rounds en Hill 1984]. De hypoxische vasoconstrictie is ondermeer afhankelijk van calcium en is gelokaliseerd op arteriolair niveau [Straub 1985, Voelkel 1986]. De vasoconstrictieve reactie in het pulmonale vaatbed, een lagedruksysteem, koppelt doorbloeding aan ventilatie ("matching" fenomeen) om aldus verdere hypoxaemie te voorkomen.

Onderzoek bij mens en dier heeft getoond dat chronische hypoxie leidt tot structurele vaatwandafwijkingen, zoals mediahypertrofie van de arteriolen [Hicken et al 1968, Rabinovitch et al 1979]. Zowel in studies bij hypoxische longpatiënten als bij patiënten met milde longafwijkingen, verblijvend op grote hoogte, is waargenomen dat proliferatie van glad spierweefsel in de arteriolaire intima optreedt. Deze afwijkingen zijn waargenomen bij gezonde proefpersonen onder identieke omstandigheden [Heath en Williams 1981]. Uit de studies op grote hoogte met gezonde vrijwilligers is voorts gebleken dat pulmonale hypertensie gedeeltelijk voorkomen kan worden door het gebruik van calcium-antagonisten; bij terugkeer in zturstofrijke lucht blijkt deze af wijking reversibel [Heath en Williams 1981, Widimsky el al 1980]. Bij patiënten met chronisch obstructief longlijden lijkt de pulmonale hypertensie multifactorieel van aard en minder reversibel. Behandeling met onderhoudstherapie met zuurstof thuis (OZT) leidt slechts tot stabilisatie of milde rediuctie van de pulmonale hypertensie [Weitzenblum et al 1985].

Als verklaring voor de intima-afwijkingen kan gedacht worden aan de invloed van roken en aan de mechanische eigenschappen van de long. Door middel van post-mortem onderzoek van longweefsel afkomstig van patiënten behandeld in de OZT-trials, is het bestaan van de intima-afwijkingen bevestigd [Magee el al 1988]. Deze groep van Canadese onderzoekers vergeleek tegelijkertijd weefsel, verkregen na longchirurgie bij forse rokers met normale 
bloedgassen en milde longfunctiestoornissen, met dat van niet-rokers met normale bloedgassen en longfunctie. Daarbij werden soortgelijke arteriolaire intima-verdikkingen alleen in de groep van rokers vastgesteld, terwijl hypertrofische afwijkingen van de media (muscularisatie) slechts in de OZT-groep waargenomen werd. Onderzoekers wit Sheffield hebben identieke waamemingen verricht bij patiënten met hypoxisch cor pulmonale, overigens allen rokers [Wilkinson et al 1988].

De tweede gedachte betreft de invloed van de longmechanica. In een studie specifiek gericht op patiënten met puur emphyseem bleek het optreden van pulmonale hypertensie gerelateerd aan de mechanische longafwijkingen [Oswald et al 1989]. Recent onderzoek, eveneens postmortem, vanuit de NOTT-studie suggereert dat het optreden van cor pulmonale vooral samenhangt met de ernst wan de perifere luchtwegvernauwing en minder met de mate van emphyseem of slijmproduktie [Jamal et al 1990]. Anderzijds hebben verschillende klinische studies de relatie tussen longfunctiegegevens en het optreden van pulmonale hypertensie niet kunnen bevestigen, met name in een grote europese studie met 595 patiënten [B ishop an Gross 1981]. Andere factoren die de pulmonale vaatweerstand beïnvloeden zijn polycythaemie, verkleining van het vaatbed na chirurgie of het gevolg van longemphyseem, en respiratoire acidose [Matthay et al 1990, Rounds en Hill 1984].

\subsection{Pathofysiologie}

In de pathofysiologie van het cor pulmonale concentreert de aandacht zich op twee zaken, namelijk de rechter-ventrikelfunctie en het ontstaan van water- en zoutretentie. Beide aspecten spelen een rol in het klinische beeld van het gedecompenseerde cor pulmonale [Klinger en Hill 1991].

Het rechter ventrikel is normaliter te karakteriseren als een volumepomp en het pulmonale vaatbed als een lagedruksysteem. Dit maakt het ventrikel zeer gevoelig voor veranderingen in de pulmonale valweerstand (PVR), de belangrijkste factor in de afterload [Morrison 1983]. De pompfunctie van het ventrikel, te meten aan de ejectiefractie en het slagvolume, wordt verder bepaald door de preload en de contractiliteit van het hart. De preload geeft de vulling weer, te meten als het einddiastolisch ventrikelvolume, en de contractiliteit is onder andere afhankelijk van de coronairfunctie en de zuurstofspanning in het bloed [Hurford en Zapol 1983]. Aanpassingen in preload en contractiliteit compenseren acute of chronische veranderingen in de afterload. Het acute cor pulmonale, zoals bij een massale longembolie, leidt tot acute dilatatie van het rechter ventrikel, terwijl bij chronische afwijkingen het ventrikel tijd heeft 
om te hypertrofièren. Bij longenbolleên spelen secundaire mechanismen, zoals vasoconstrictie en bronchoconstrictie door uitstoting van plaatjesgebonden serotonine (5-hydroxytryptamíne), een belangrijke rol [Huval et al 1983].

Het klinische beeld van het cor pulmonale onderscheidt zich wezenlijk van het beeld van linker ventrikelfalen. Bij het cor pulmonale weerspiegelen oedemen niet direct een falende linker ventrikel en longoedeem. Integendeel, bij stabiele patiënten zijn de contractiliteit en het hartminuutvolume veelal normal of zelfs licht verhoogd [MacNee et al 1988]. Bij] inspanning verloopt de einddiastolische druk-volumecurve normaal [Biernackie et al 1988]. Slechts in een eindstadium van het gedecompenseerde cor pulmonale stijgen de vullingsdrukken met kans op septumverplaatsing, verkleind linker-ventrikelvolume en verdere daling van het hartminuutvolume.

Deze haemodynamische bevindingen verklaren niet volledig de oedeemvorming bij het cor pulmonale. Het normale tot verhoogde hartminuutvolume pleit tegen forward failure als oorzaak voor vochtretentie. De waarneming dat periodes met oedeemvorming bij patiënten met obstructief longlijden veel eerder optreden dan bij patiënten met primaire pulmonale hypertensie, pleit ook voor een andere oorzaak van het oedeem. Als alternatieve theorie is wel genoemd de invloed van rechter-ventrikelfalen op de nier [Firth et al 1988]. Een exacerbatie van het obstructief longlijden zou een acute pulmonale en veneuze drukstijging veroorzaken, gevolgd door retrograde stuwing van de nier. Bij gezonde personen echter leidt acute verhoging van de centrale veneuze druk tot natriurese [Epstein 1978].

Een tweede aangrijpingspunt, los van het acute moment bij een exacerbatie, is de invloed van het $\mathrm{CO}_{2}$-gehalte op de oedeemvorming. Uit de kliniek is bekend dat oedeem met name optreedt wanneer er sprake is van chronische hypoxie in combinatie met hypercapnie [Reihman et al 1985]. Daarentegen blijwen patiënten met een ernstige luchtwegobstructie, doch normale bloedgaswaarden, lang zonder oedeem. Deze waarnemingen pleiten voor een nietcardiale oorzaak van het oedeem en suggereren een invloed van chronische hypercapnie en/of hypoxie.

\subsection{Pathofysiologische effecten van hypercapnie en hypoxie}

Hypercapnie heeft ondermeer effecten op de gaswisseling, het zenuwstelsel, de nieren en het hart-vaatstelsel [Weinberger et al 1989]. Zo treedt er verlaging op van de $\mathrm{PaO}_{2}$ door verschuiving van de zuurstofdissociatiecurve evenals contractiliteitsvermindering van spierweefsel (diafragma!). Met betrekking tot de circulatie veroorzaakt hypercapnie 
systemische vasodilatatie [Heistad en Kontos 1983]. Hypercapnie blijkt tevens te kunnen leiden tot vasodilatatie van het vaatbed in huid, spierweefsel, hart, hersenen en darmen. Terwijl dit in sommige gevallen een direct effect van het $\mathrm{CO}_{2}$-gehalte lijkt te betreffen, speelt bij de hersenen waarschijnlijk de toegenomen intracellulaire $\mathrm{H}^{+}$-concentratie een rol.

Het is de vraag wat de precieze pathofysiologische betekenis is van de vasodilatatie. $\mathrm{Bij}$ gelijkblijven van de bloeddruk zou een daling van de vaatweerstand een toename betekenen wan het hartminuutvolume en zuurstoftransport. In geval van hypercapnie kan men zich voorstellen dat snelle aanpassingen in de $\mathrm{PaCO}_{2}$ de circulatie ongunstig beïnvloeden [Breivik et al 1973]. Anderzijds zou hypercapnie, gepaard gaande met een hoog hartminuutvolume, verdere circulatoire aampassing kunnen belemmeren. Zo bleek in een studie bij patiënten ingesteld op OZT, na onthouden van de zuurstoftoediening, dat alleen patiënten met een normaal $\mathrm{CO}_{2}$-gehalte in staat waren het zuurstoftransport op peil te houden [Selinger et al 1987]. In tegenstelling tot de perifere vasodilatatie treedt er in de pulmonale vaten vasoconstrictie op; deze wordt versterkt door de reeds aanwezige vaatwandhypertrofie [Harvey et al 1967]. Het is niet geheel duidelijk of de verhoogde $\mathrm{PaCO}_{2}$, dan wel de verlaagde $\mathrm{pH}$, ingeval van respiratoire acidose, de vasoconstrictie bewerkstelligt [Malik en Kidd 1973]. Een gelijktijdig optreden van hypoxaemie en acidaemie doet de vasoconstrictieve respons veel heftiger verlopen [Matthay et al 1990].

\subsubsection{Effecten op het sympatische zenuwstelsel}

Het sympathische zenuwstelsel als regulatiemechanisme in de haemodynamiek is uitgebreid onderzocht met betrekking tot de werking van baroreceptoren en reflexmechanismen. De invloed van de bloedgaswaarden op de sympathicustonus verloopt via centrale en perifere chemoreceptoren. De centrale receptoren lijken het gevoeligst voor hypercapnie en de perifere, gelokaliseerd in de carotislichaampjes, voor het optreden van hypoxie.

Daar hypercapnie en hypoxie meestal samengaan en beide factoren meerdere processen in gang zetten, is het moeilijk om door meting van haemodynamische variabelen de exacte betekenis van de sympathicusstimulatie vast te stellen. Door middel van microneurografie is echter aangetoond dat hypercapnie en hypoxie de post-ganglionaire sympathicusactiviteit stimuleren en de noradrenaline-spiegel verhogen. In geval van hypercapnie zijn ondanks voorafgaande vasodilatatie secundaire bloeddrukstijgingen beschreven. Hoewel de betrouwbaarheid van het plasma noradrenaline-gehalte als maat voor de sympathicusactiviteit wisselend wordt beoordeeld [Folkow et al 1983], zijn bij hypercapnische patiênten hoge spiegels beschreven. De hoogte correleerde direct met de $\mathrm{PaCO}_{2}$, de hartslag en de mPAP, en 
omgekeerd met de $\mathrm{PaO}_{2}$ [Hendriksen et al 1980]. De combinatie wan hypercapnie met hypoxie werkt synergistisch [Somers et al 1988].

Experimenteel onderzoek bij ratten toont aan dat chronische hypoxie de carotislichaampjes in omvang doet toenemen met een stijging van de hoeveelheden opgeslagen dopamine en noradrenaline [Barer en Pallot 1986, Dhillon et al 1984].

Klinisch onderzoek bij patiënten, die beademd worden in aansluiting op een coronary bypass-operatie, geeft weer dat ook de "directe" effecten van hypercapnie op de pulmonale arteriewand via catecholaminen kunnen ontstaan [Vitanen et al 1989]. Dier-experimentele waarnemingen waarbij $\beta$-blokkade de door hypercapnie geïnduceerde vasoconstrictie versterkt, sluiten hierbij aan [Porcelli en Bergofsky 1973]. De $\beta$-receptor betreft hier het $\beta_{2}$-type in de vaatwand [Hyman et al 1981, Vik-Mo el al 1987], die bij stimulatie vasodilatatie veroorzaakt, terwijl blokkade juist het effect van de $\alpha$-receptor gemedieerde vasoconstrictie doet overheersen.

De gevolgen van stimulatie van het sympatische stelsel komen naar voren bij het zogenaamde slaap-apneu-syndroom [Clark et al 1980, Somers el al 1988]. Er zijn aanwijzingen dat het slaap-apneu-syndroom en cardiovasculair lijden aan elkaar gerelateerd zijn |Hirschkowitz et al 1989]. Bij patiënten met het syndroom komt meer hypertensie voor en omgekeerd is er een verhoogde incidentie van slaap-apneu bij hypertensieve patiënten [Burach et al 1977, Fleicher et al 1985]. De adrenerge respons op hypoxie blijkt bij hypertensieven vele malen intensiever te verlopen dan bij normotensieven [Trzebski et al 1982]. Behandeling van het apneu-syndroom resulteert tevens in een daling van de gemiddelde bloeddruk [Guilleminault et al 1981]. Theoretisch is het mogelijk dat overmatige symphaticusactiviteit een schakel vormt tussen hypercapnie en circulatoire veranderingen. Definitief bewijs is echter zeker niet voorhanden [Stradling 1989].

\subsubsection{Effecten op het renine-angiotensine-aldosteron systeem en de nieren}

De invloeden van hypoxie en hypercapnie op het renine-angiotensine-aldosteron systeem (RAAS) en de nieren zijn nauw met elkaar verweven. Enkele decennia geleden werd reeds gewezen op het verband tussen de bloedgaswaarden en de nierdoorbloeding [Aber en Bishop 1965).

Bij een patiëntengroep met normocapnie en milde hypoxaemie treden weinig stoornissen op in de plasmaspiegels van renine en A II en in de nierperfusie [Colice 1988]; de problemen beginnen pas bij de patiënten met chronische hypercapnie. De respiratoire acidose leidt tot een toename van $\mathrm{H}^{+}$-excretie en $\mathrm{HCO}_{3}$-retentie door de nier, waardoor de tubulaire 
reabsorptie van natrium zou kunnen stijgen [Heinemann 1980]. In periodes van oedeemworming kan deze metabole compensatie het gebruik van lisdiuretica in de weg staan. Deze middelen verergeren namelijk de alkalose, hetgeen dan gevolgd kan worden door verdere $\mathrm{CO}_{2}$ stapeling en hypoventilatie [Hurewitz en Bergotsky 1988].

Naast de directe metabole verschuivingen, beïnvloedt hypercapnie waarschijnlijk de sympatische tonus in het niervaatbed [Anderson et al 1983]. Dit zou een verklaring kunmen vormen voor de vermindering van de renal plasma flow (RPF), zoals deze gevonden is door Farber en medewerkers. [Farber en Manfredi 1984]. Klinisch komt deze fase overeen met de patiënt in een stabiele situatie, zonder oedemen, en met milde hypercapnie en/of hypoxie. De afname van RPF gaat nog niet samen met reductie van de glomerulaire filtratie snelheid (GFR) of toename in de A II-spiegels [Olver et al 1989]. De daling in RPF treedt op bij een normaal hartminuutvolume [Mannix et al 1990], hetgeen wijst op een selectieve renalle vasoconstrictie.

Bij progressie van de hypoxie, in combinatie met de hypercapnie, derailleert het systeem. De RPF daalt verder en ook de GFR neemt nu af. Het RAAS wordt gestimuleerd, hetgeen leidt tot verhoogde plasma, A II en plasme-renine spiegels [Matthews en Peacock 1989, Reihman et al 1985].

De produktie van anti-diuretisch hormoon $(A D H)$, versnelt de ontwikkeling van het gedecompenseerde cor pulmonale met de kenmerkende hyponatriemie en oedemen. In de oedeemperiode correleert de mate van hypercapnie met de beperkingen in RPF en uitscheiding van water en zout [Farber et al 1982].

Bij een reeds gestoorde nierfunctie lijkt hypoxie dus de druppel die de emmer doet overlopen. In acute studies bij zowel oedemateuze als stabiele patiënten bleek dat zuurstoftoediening of het staken daarvan de zoutuitscheiding beïnvloedde zonder wijziging in RPF of hormonale status [Colice 1988, Mannix et al 1990]. Overigens dient te worden opgemerkt dat bij de introductie of het onthouden van zuurstoftoediening de secundaire effecten op de niercirculatie meespelen. Zo werd in een ballansstudie de overgang van normoxie naar ernstige hypoxie niet alleen gekenmerkt door daling van de GFR, doch ook door compensatoire hyperventilatie, met een daling van de bloeddruk en een stijging van de pH [Reihman et al 1985].

\subsubsection{De plaats van het atriaal natriuretisch peptide (ANP)}

ANP is een peptide met natriuretische, vasodilaterende en bronchodilaterende eigenschappen [Hulks et al 1989, Laragh 1985]. Bij toename van druk- en met name rek in het rechter atrium, 
zoals bij volumeoverbelasting of ritmestoornissen, wordt het peptide gesecerneerd uit myocyten.

Bij patiênten met pulmonale hypertensie van verschillende oorsprong blijkt het plasma-ANP verhoogd. De basale waarden zijn gerelateerd aan haemodynamische variabelen als de rechter-atriumdruk en de mPAP, doch ook aan de bloedgaswaarden en het haemoglobinegehalte ( $\mathrm{Hb}$ ), [Adnot et al 1989, Skwarski et al 1989]. In een multivariaat-analyse bleek de sterkste correlatie aanwezig met de $\mathrm{PaCO}_{2}$ en het $\mathrm{Hb}$ [Adnot et al 1989].

Tijdens de behandeling van patiënten met een gedecompenseerd cor pulmonale was het beloop van de ANP-spiegel gerelateerd aan het gewichtsverlies [Skwarski et al 1989]. In een aeute studie gaf de toediening van zuurstof, ter correctie van de hypoxaemie, geen verandering in ANP- of renine-spiegels te zien [Winter et al 1989].

Experimenteel onderzoek toont aan dat toediening van ANP, in farmacologische dosering, het pulmonale vaatbed verwijdt in geval van hypoxische vasoconstrictie [Adnot et al 1988, Will en Council 1986]. Extractie van ANP in het pulmonale vaatbed is beschreven, doch er zijn ook studies waarin geen verschil in centrale en perifere spiegels werd vastgesteld [Skwarski et al 1989 ; Weselcouch et al 1985].

Tijdens de infusie van ANP in farmacologische dosering, gaat de pulmonale en systemische vasodilatatie gepaard met een daling van de $\mathrm{PaO}_{2}$, waarschijnlijk door toename van de shuntfractie [Adnot et al 1989].

Een opvallende waarneming tijdens ANP-infusie was verder de daling van het aldosterongehalte. Al eerder was een ralatief laag aldosterongehalte, bij toegenomen renineconcentratie, opgemerkt bij patiënten met chronische hypoxie, zodanig dat op grond hiervan gedacht zou kunnen worden aan een situatie analoog aan die van ACE-inhibitie [Raff en Levy 1986]. Verder blijkt dat de vasodilaterende werking van ANP versterkt wordt gedurende hypoxie en een verhoogd noradrenaline-gehalte [Doorenbos 1990].

Het lijkt er op dat het ANP-secretieproces fungeert als een homeostatisch mechanisme met betrekking tot het voorkómen van volumeoverbelasting en drukverhoging. De aanwezigheid van receptoren voor ANP en angiotensine II in tal van organen en de tegengestelde effecten die deze peptiden hebben, versterken de hypothese dat ANP functioneert als de endogene antagonist van het RAAS [Johnston et al 1989]. Recent onderzoek geeft steun aan de gedachte dat het ANP een compensatoir in plaats van een primair mechanisme weergeeft [Stewart et al 19911. Bij patiënten met cor pulmonale veroorzaakt toediening van zout geen toename in de zoutexcretie, ondanks verhoogde basale spiegels van het ANP en een normale secretie van het peptide tijdens de zoutbelasting. 


\subsection{Diagnostiek}

De diagnostiek verloopt langs twee wegen: bepaling van de haemodynamische status en het vastleggen van de mate waarin de gaswisseling is gestoord. De bloedige metỉng met behulp van de thermodilutiecatheter geldt als standaard voor de bepaling van de MPAP. De invasieve methode is echter duur, belastend en niet zonder risico's voor de patiënt [Robin 1985]. Daartegenover staat dat veel informatie verkregen wordt indien de rechtscatheterisatie gecombineerd wordt met bepaling van arteriële en gemengd-veneuze gaswaarden en een nauwkeurige interpretatie van de drukcurves [Sharkey 1987]. Een typerend voorbeeld is de vergroting van het rechter hart met tricuspidalis-insufficientie, waardoor de thermodilutiecurve vlak en traag verloopt en de rechter-atriumcurve een prominente $\mathrm{V}$-golf toont zonder verloop tijdens inspiratie. Bij de vaststelling van pulmonale hypertensie kunnen lichamelijk onderzoek, elektrocardiografie en thoraxfoto met meting van de diameter van de dlalende tak van de rechter arteria pulmonalis, belangrijke aanwijzingen geven, doch veelal zijn deze weinig specifiek [Matthay et al 1981].

De meting van de rechter-ventrikelejectiefractie met behulp van isotopen correleert niet goed met de mPAP en heeft geen prognostische waarde [France et al 1988]. Bij de beeldvormende technieken is een belangrijke plaats aanwezig voor de Doppler-echocardiografie en de magnetische resonantie-imaging (MRI), met name om dimensies en ventrikelhypertrofie vast te stellen [Himelman et al 1988]. Het voorspellen van de mPAP met behulp van de echocardiografie geeft nog wisselende resultaten [Marchandise 1987]. De niet-invasieve methoden zijn eenvoudig uit te voeren en regelmatig te herhalen.

Van de "niet-invasieve" methoden lijkt de bepaling van de arteriële gaswaarden het best te correleren met de mPAP in rust [Bishopen Gross 1981], hoewel de arteriële zuurstofverzadiging op zich zelf slechts de helft voorspelt van de variantie in mPAP [Lockhart et al 1969, Rizzato et al 1975].

De toepassing van de transcutane pols-oxymetrie maakt het mogelijk op niet-invasieve wijze de arteriële zuurstofsaturatie $\left(\mathrm{SaO}_{2}\right)$ en de hartfrequentie te vervolgen [Gimeno Ortega 1986]. Vooral tijdens inspanning en in machtelijke uren tijdens de REM-slaap zijn de bepalingen van waarde [Hedemark en Kronenberg 1982]. Zo komen bij een kwart van de patiënten, bij wie de $\mathrm{PaO}_{2}$ overdag groter dan $60 \mathrm{mmHg}$ is, nachtelijke periodes van desaturatie voor [Fletcher et al 1987]. Dezelfde groep van onderzoekers heeft aangetoond dat bij patiénten met nachtelijke desaturatie ernstiger orgaanschade en pulmonale hypertensie optreedt in vergelijking tot patiënten zonder nachtelijke desaturatie [Fletcher et al 1989]. 
In een onderzoek, specifiek gericht op dle detectie van milde pulmonale hypertensie, bleek de bepaling van de $\mathrm{PaO}_{2}$ en de $\mathrm{PaCO}_{2}$ in rust en inspanning de aanwezigheid van pulmonale hypertensie met een nauwkeurigheid van $80 \%$ te voorspellen [Keller et al 1986].

Het geheel overziend moeten wij stellen dat de individuele voorspellende waarde van de niet-inwasieve methoden gering is. Echter de juistheid waarmee een combinatie van methoden de aanwezigheid van milde of ernstige pulmonale hypertensie voorspelt, is hoger en bedraagt $80-90 \%$ [Bishop en Csukas 1989].

\subsection{Theraple}

Aan de specifieke behandeling van de pulmonale hypertensie gaan belangrijke algemene maatregelen met betrekking tot preventie en behandeling van infecties en luchtwegobstructie vooraf [Peacock 1990, Postma et al 1985]. Tot deze algemene matregelen behoren de toediening van bronchusverwijders, corticosteroïden en zo nodig antibiotica. Het stoppen van roken is een belangrijk advies. In de specifieke behandeling van het cor pulmonale kunnen worden onderscheiden: het gebruik van digoxine, diuretica, vaatverwijders en zuurstof. Slechts de instelling van onderhoudstherapie met zuurstof thuis heeft daarin een vaste plaats verworven [Anthonissen 1983, Rubin 1987, Whyte en Flenley 1988].

\subsubsection{Digitalis en diuretica}

De pathofysiologische kenmerken van het cor pulmonale, de toegenomen afterload, de normale contractiliteit en de preload-aanpassing beperken het indicatiegebied voor digitalis en diuretica, dit in tegenstelling tot de situatie bij het linker ventrikel falen.

Het gebruik van deze middelen dient daarom gerelateerd te zijn aan de aanwezigheid van een toegenomen bloedvolume met linker-ventrikelfalen en/of atriumfibrilleren met snelle ventrikelrespons [Green en Smith 1977].

In de overige situaties kunnen diuretica het hartminuutvolume dusdanig verminderen dat de bloeddruk daalt en de nierdoorbloeding verder afneemt. De metabole gevolgen, zoals de hypokaliemie en de toegenomen reabsorptie van bicarbonaat, versterken de hypercapnie en de gevoeligheid voor ritmestoornissen bij digitalisgebruik. Een aparte plaats is weggelegd voor acetazolamide, een carbo-anhydraseremmer, die de uitscheiding van bicarbonaat bevordert. Gezien de sterke neiging tot retentie van natrium en bicarbonaat, valt het gebruik van dit middel aan te raden bij respiratoire acidose, uiteraard onder frequente controle van de $\mathrm{pH}$ en het serum-bicarbonaatgehalte. 
De invloeden van digitalis op het rechter ventrikel zijn complex. De glycosiden verhogen de contractiliteit wan het myocard, doch de rechter-ventrikelfunctie, zowel in rust als tijdens inspanning, verbetert niet in klinische studies [Brown et al 1984, Matthay et al 1990]. Voorts zijn er aanwijzingen dat digitalis pulmonale vasoconstrictie veroorzaakt [Kim en Aviado 1961].

\subsubsection{Het gebruik van vaatverwijders bij de behandeling van pulmonale hypertensie}

Op theoretische gronden is het gebruik van vaatverwijders aantrekkelijk. Immers een verlaging van de mPAP zou de prognose gunstig kunnen beïnvloeden en door de toename in zuurstoftransport zou de perifere oxygenatie kunnen verbeteren [Bergofsky 1983].

In de praktijk liggen de zaken echter minder eenvoudig. Enerzijids is er sprake van bijwerkingen, anderzijds ontbreken voldoende lange-termijnstudies om onderhoudstherapie te rechtvaardigen [Klinger en Hill 1991].

In het algemeen zijn calcium-antagonisten in staat pulmonale vasodilatatie te bewerkstelligen onder verschillende omstandigheden. De effecten lijken af te hangen van de ernst van de hypoxische vasoconstrictie. Bij een normale mPAP en PVR hebben deze middelen geen duidelijke invloed op de pulmonale haemodynamiek [Mols et al 1986]

Bij stabiele patiënten met hypoxisch longlijden en een verhoogde mPAP veroorzaken calcium-antagonisten een toename in hartminuutvolume zonder verandering in MPAP. De PVR daalt gelijktijdig met de stijging van het hartminuutvolume. De combinatie van zuurstof en nifedipine werkt additief op de daling in PVR [Kennedy et al 1984].

In enkele studies zijn de chronische effecten van calcium-antagonisten beschreven. $\mathrm{Na}$ respectievelijk 2, 5 en 6 maanden werden de verbeteringen in de haemodynamiek niet vergezeld van klinische vooruitgang [Bratel et al 1986, Meurice et al 1989, Sturani et al 1983].

In een placebo-gecontroleerde studie met 60 patiënten bleek na 1 jaar vervolg geen verschil in overleving of opnamedagen opgetreden te zijn onder invloed van nifedipine [Vestri et al 1988]. Wel was in de nifedipine-groep de dyspnoe verminderd. De helft van de patiënten in deze studie werd met OZT behandeld om normoxie te handhaven.

Tijdens een exacerbatie bij patiënten met pulmomale hypertensie treedt een acute vasoconstrictie op met stijging van de mPAP, welke zowel door zuurstof als nifedipine effectief geblokkeerd wordt [Simonneau et al 1981]. In dit geval heeft de combinatie geen aanvullend effect.

Gedurende inspanning kunnen scherpe stijgingen optreden in MPAP en PVR, ook bij patiënten met normale rustdrukken [Dantzker en d'Alonso 1986]. Bij patiënten met cor pulmonale 
gaat dit gepaard met tachycardie en daling van de ejectiefractie [Mahler et al 1986]. Vatverwijders beperken de excessieve drukstijgingen, echter zonder duidelijke verbetering van het prestatievermogen. Na 4 maanden behandeling met hydralazine werd geen verbetering in het prestatievermogen vastgesteld [Dal Nogare en Rubin 1986]. Hoewel het zuurstoftransport toenam werd geen verandering in het verbruik waargenomen.

Het gebruik van directe vaatverwijders kent vele bijwerkingen, onder andere bloeddrukdaling en verslechtering in de $\mathrm{PaO}_{2}$. De door de vasodilatatie veroorzaakte toename in hartminuutvolume kan zelfs aanleiding geven tot mPAP-stijging, zoals opgemerkt in acute studies met hydralazine [Lupi-Herrera et al 1984]. De daling in de $\mathrm{PaO}_{2}$ is een gevolg van pulmonale vasodilatatie in van te voren slecht doorbloede gebieden, waardoor de shuntfractie toeneemt [Ringsted et al 1989].

Van de nieuwere groepen vaatverwijders verdienen de serotonerge receptor-antagonisten extra aandacht. Serotonine, opgeslagen in bloedplaatjes, zou immers een rol kunnen spelen in het ontstaan van pulmonale hypertensie; het versterkt de vasoconstrictieve werking van de catecholaminen en A II [Van Nueten 1985].

In een vergelijkend onderzoek met nitroprusside natrium, had de $\mathrm{S}_{2}$-receptor-antagonist ketanserin een gunstiger invloed op de PVR en shuntfractie bij patiënten na coronairchirurgie [Van der Starre 1988].

In tegenstelling tot de arteriële vaatverwijders hebben de $\alpha$-blokkers, de nitraten en ACEremmers zowel een effect op de pre- als op de afterload. De ACE-remmers zouden kunnen leiden tot verbetering van de haemodynamiek indien activatie van het RAAS een rol speelt in het onderhouden van de pulmonale hypertensie. De resultaten van korte-termijnstudies zijn echter nog tegenstrijdig [Burke et al 1985, Patakas et al 1988].

In verschillende reviews zijn de diverse klassen vaatverwijders besproken [Denolin 1988, White en Flenley 1988]. De meeste aandacht blijft uitgaan naar de calcium-antagonisten en de ACEremmers. Beide groepen geneesmiddelen zijn goed bruikbaar voor de behandeling van verhoogde bloeddruk bij longpatiënten, hoewel de ACE-remmers kunnen leiden tot versterkte hyperreactiviteit van het bronchusslijmvlies en hoestprikkels [Löłdahl 1989; Semple 1986]. Met betrekking tot de behandeling van het cor pulmonale is het van belang dat de calcium-antagonisten zowel natriuretische als bronchodilaterende effecten hebben. De plaats van de ACE-remmers lijkt vooral van belang gezien de gemengd arterieel-veneuze vaatverwijding en de gunstige invloed op de nierdoorblloeding [Suki 1989]. 
Met betrekking tot de gunstige invloed van haemodynamische effecten van valatverwijders blijven veel vragen bestaan [Rubin 1987]: Hoe zijn de invloeden op lange termijn op de overleving, op de kwaliteit van leven? Heeft de combinatie van zuurstof plus valuerwijder voordelen boven zuurstof alleen? Het antwoord op deze vragen kan echter nog niet gegeven worden.

\subsubsection{Het gebruik van onderhoudstherapie met zuurstof}

De instelling op OZT heeft een gunstige invloed op de prognose van patienten met chronisch hypoxisch obstructief longlijden. Enkele grote studies, waaronder de Nocturnal Oxygen Therapy Trial [NOTT 1980], en de Medical Research Council Working Party, [MRCWP 1981], hebben dit bevestigd. Hoe langer de OZT per dag, des te beter. OZT stopt de progressieve ontwikkeling van de pulmonale hypertensie, soms treedt zelfs reductie van de mPAP op [Weitzenblum et al 1985].

Toch profiteren niet alle patiënten qua overleving wan OZT en de vraag is gerezen of er wel een rol is voor beinvloeding van de haemodynamische variabelen met betrekking tot de overleving tijdens OZT.

De analyse van de MRCWP toont aan dat pas na anderhalf jaar een verschil in overleving optreedt tussen de patiëntengroepen met en zonder nachtelijke zuurstoftoediening. Mogelijk is dit te verklaren door de inclusie van veel patiënten met ernstige pulmonale hypertensie en hypercapnie, (gemiddelde mPAP $34 \mathrm{mmHg}, \mathrm{PaCO}_{2} 54 \mathrm{mmHg}$ ), welke allen een of meerdere periodes van oedeem hadden doorgemaakt.

In de NOTT, met meer dan 200 patiënten, bleek de overleving gerelateerd aan de daling van de mPAP in het eerste halfjaar van de OZT [Timms et al 1985]. In de verschillende groepen, nachtelijk zuurstoftoediening versus 18 uur zuurstof per etmaal, werd tevens een verband met de uitgangswaarde van de PVR en het slagvolume vastgesteld. In het algemeen stak de overleving in deze studie gunstig af tegen die in de MRCWP. De gemiddelde mPAP was $29 \mathrm{mmHg}$, de $\mathrm{PaCO}_{2} 43 \mathrm{mmHg}$ en $41 \%$ van de patiënten had in de voorgeschiedenis een periode van oedeem meegemaakt.

Onderzoekers uit Sheffield, welke ook participeerden in de MRCWP, hebben follow-up gegevens tot 12 jaar na OZT gepubliceerd [Cooper et al 1987]. In deze serie trad na ongeveer 11 jaar een snelle daling in de overlewing op, niet gerelateerd aan enige haemodynamische parameter. De owerleving in de verschillende studies is samengevat in figuur 2.1.

Het mechanisme waardoor OZT de overleving bij een deel der patiënten verbetert, is niet geheel verklaard. Als verklaringen zijn genoemd: de verbeteringen in de schakels van het 
Figur 2.1: Lange-termijn overleving tijdens $O Z T$.

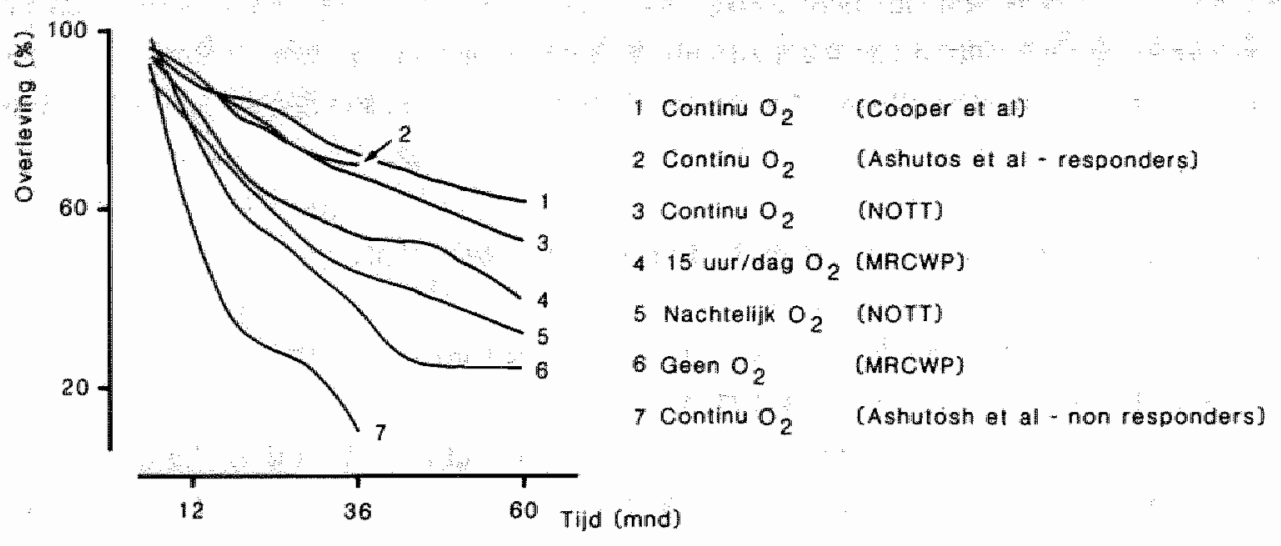

zuurstoftransport, opheffen wan de hypoxische vasoconstrictie, contractiliteitstoename van het myocard en toename in zuurstofaanbod op weefselniveau.

Het tijdstip waarop OZT ingesteld wordt, lijkt van groot belang. In een periode dat de pulmonale hypertensie nog reversibel is, is de invloed op de overleving waarschijnlijk het grootst. In een follow-up-studie na OZT bleek 70\% van de responders na 3 jaar in leven, in tegenstelling tot 10\% van de niet responders [Ashutosh en Dunsky 1987]. Het responder zijn was gedefinieerd als een daling van ten minste $5 \mathrm{mmHg}$ in mPAP na 48 uur toediening van zuurstof. De waarde van het zuurstofverbruik $\left(\mathrm{VO}_{2}\right)$ bij maximale inspanning correleerde met de respons op zuurstof en had een gelijke voorspellende waarde. Inmiddels zijn nietinvasieve metingen van de effectieve capillaire bloedstroom in de long beschreven, welke een alternatief kunnen vormen voor de invasieve vaststelling van het responderschap.

Een tweede definitie van respons op zuurstof geeft de verandering weer in het dode-ruimtevolume ten opzichte van het teugvolume (VD/VT) [Hunt et al 1989]. Toeneming tijdens zuurstoftoediening, een respons, betekent herverdeling van de bloedstroom naar slecht geventileerde gebieden. In een kleine groep van 8 patiënten bleek de VD/VT-toename gerelateerd aan mPAP-daling.

Als indicaties voor toediening van $\mathrm{OZT}$ worden gehanteerd een $\mathrm{PaO}_{2} \leq 55 \mathrm{mmHg}$ in een stabiele fase en een $\mathrm{PaO}_{2} \leq 59 \mathrm{mmHg}$ indien er aanwijzingen zijn voor een cor pulmonale of secundaire polycythaemie.

De laatste jaren zijn er ontwikkelingen in de toedieningswijzen van OZT: het gebruik van vloeibare zuurstof door middel van de transtracheale catheter is in opkomst [Petty 1990]. Zowel met betrekking tot cosmetische als mobiliteitsaspecten zijn deze vormen aantrekkelijk 
voor de patiènt in vergelijking met de vaste opstelling thuis (cilinder of concentrator). Het is nog onduidelijk of deze transtracheale toediening van zuurstof de overleving verder zal verbeteren WWalsh en Gowan 1990).

\subsection{Prognose}

Vóor de introductie van OZT hadden de diagnoses pulmonale hypertensie en cor pulmonale een sombere klank met betrekking tot de prognose van het hypoxisch chronisch obstructief longlijden. De 5-jaars overleving voor patiënten met het cor pulmonale bedroeg ongeveer 30\% [Bardsley en Howard 1986]. Temidden wan prognostische factoren als de mate van ernst, reversibiliteit en adequate behandeling van de luchtwegobstructie, naast hyperinflatie en het roken [Diener en Burrows 1975. Traver et al 1979, Peto et al 1983, Postma et al 1979], bleek het cor pulmonale een onafhankelijke risicofactor [Weitzenblum et al 1981. Anthonissen et al 1986]. Overigens lijkt het verdere beloop van de pulmonale hypertensie, na de eerste vaststelling, weinig prognostische betekenis te hebben [Weitzenblum et al 1981].

Met de komst van de OZT is de prognose verbeterd. Tegelijkertijd is de rol van de pulmonale hypertensie voor de overleving ter discussie gesteld.

Enerzijds is naar voren gebracht dat invasief haemodynamisch onderzoek overbodig is geworden, indien tot het instellen van OZT besloten is [Cooper et al 1987]. Immers de overlevingscurve wordt bepaald door de voortschrijdende luchtwegobstructie. Het gebnik van $\mathrm{OZT}$ zal de curve naar rechts verplaatsen langs de tijd-as, (figuur 2.2) waarbij de periodes van werslechterende gaswaarden en oedemen het beloop overigens well beïnvloeden [Wikinson et al 1988].

Daartegenover staan aanwijzingen dat het slagvolume van het rechter ventrikel en de reversibiliteit van de pulmonale hypertensie bij de aanvang van $O Z T$, de overleving medebepalen [Timms et al 1985]. De respons van het pulmonale vaatbed op de initiële toediening wan zuurstof heeft geleid tot de termen responder en non-responder voor $\mathrm{OZT}$ [Ashutosh et all 1987].

Mogelijk weerspiegelt het responder zijn een fase van reversibele vasoconstrictie voorafgaand aan de periode met gefixeerde vaatwandafwijkingen [Magee el al 1988]. Het is niet uitgesloten dat de rechter-wentrikelfunctie, afhankelijk wan coronair lijden en de pulmonale afterload, de overleving tijdens OZT in belangrijke mate medebepaalt [Morrison 1987]. Vroegtijdige diagnostiek is dan ook van belang om de kans op reversibiliteit van de pulmonale hypertensie en de rechter-ventrikelhypertrofie (RVH) te schatten [Matthay etal 1981]. 
Figur 2.2: Verplatusing wan de overlevingscurve door $\mathrm{OZT}$.

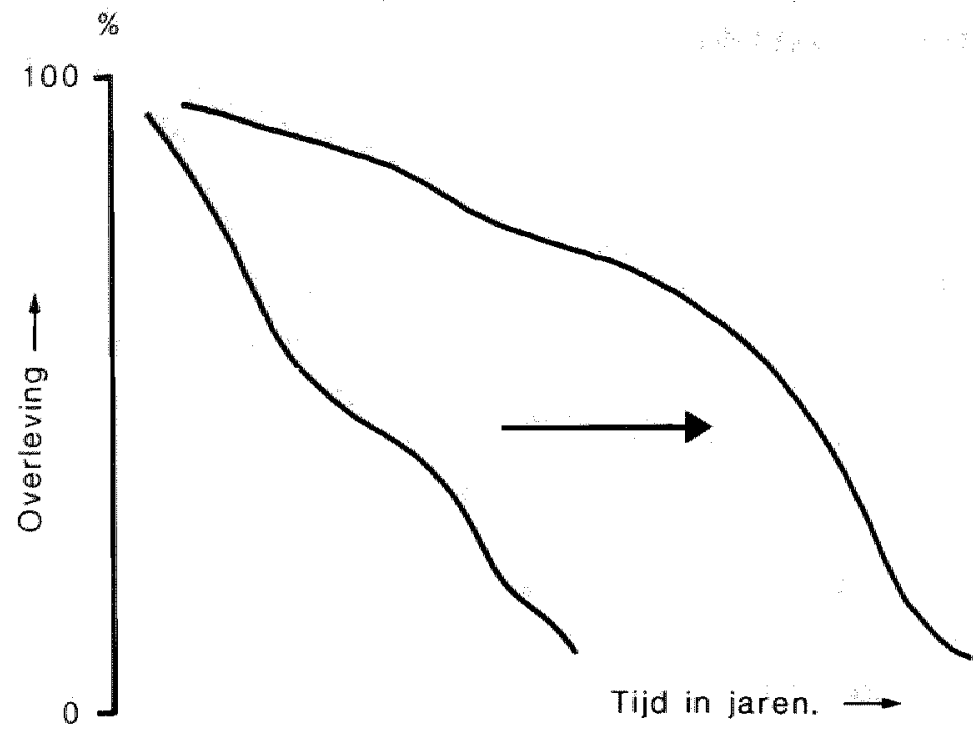

Uitgaande van de respons op zuurstof lijkt een sterke individuele benadering vereist alvorens OZT voor te schrijven. De patiënt met een laag hartminuutvolume en een gefixeerde afwijking lijkt minder kans te hebben op langdurige overleving, doch zou mogelijkerwijs nog wel kunnen profiteren van de combinatie van OZT met vaatverwijder [Hurewitz en Bergofsky 1988].

Gezien deze overwegingen leek het van belang de reactie op toediening van een vaatverwijder (calcium-antagonist, ACE-remmer) te bestuderen bi patiënten die reeds worden behandeld met zuurstof. Dit is het onderwerp van de onderzoekingen die in hoofdstuk 5 en 6 worden beschreven. 


\section{Patiënten en Methoden}

\subsection{Patiëntenselectie}

De patiëntenselectie vond plaats vanuit de klinische en poliklinische patiëntenpopulatie van de afdelingen longziekten en interne geneeskunde van het Zuiderziekenhuis te Rotterdam. De basis woor de patiëntenselectie was de aanwezigheid van chronisch obstructief longlijden. In een meerderheid van de gevallen betrof het patiënten bij wie de longziekte gecompliceerd werd door langdurige hypoxie en die klinisch ingesteld werden op onderhoudstherapie met zuurstof (16 uur per dag). Bij de overige patiënten werden de diagnose pulmonale hypertensie en/of cor pulmonale overwogen op basis van de bevindingen bij het lichamelijk onderzoek, het elektrocardiogram, het röntgenonderzoek van de thorax en de arteriële gaswaarden. Patiënten met ziektebeelden welke primair leiden tot anatomische vaatafwijkingen of patiënten met gestoorde bloedgaswaarden niet berustend op obstructief longlijden werden uitgesloten van het onderzoek.

Uiteindelijk voldeden 49 patiënten aan de gestelde criteria (zie paragraaf 3.2) en zij werden gerecruteerd voor de studie. De overleving van deze patiënten wordt beschreven in hoofdstuk 7.

Bij 40 van de 49 patiënten konden alle gegevens met betrekking tot de gaswisseling en de haemodynamische status worden verkregen. Bij 9 patiënten waren er problemen met het aanbrengen of beoordelen van de arteriële of de pulmonalis-catheter, of bleek het langdurig onderzoek te vermoeiend voor de patiënt.

De basale gegevens worden besproken in hoofdstuk 4 . Bij 14 van de 40 patiënten werden gelijktijdig bepalingen van de nierdoorstroming en de (neuro-)hormonale activiteit werricht. Met betrekking tot de farmacologische interventie, aansluitend aan het vastleggen van de basale gegevens, werd bij 28 patiënten nifedipine toegediend. De resultaten daarvan zijn vermeld in hoofdstuk 5 . Vervolgens werden de effecten van nifedipine en captopril vergeleken bij 12 patiënten (hoofdstuk 6). 


\subsection{In-en uiltsluitingscriteria}

Als insluitingscriteria werden gehanteerd:

- leeftijd tussen de 30 en 80 jaar.

- chronisch obstructief longlijden.

- verdenking op secundaire pulmonale hypertensie of cor pulmonale.

Als uitsluitingscriteria werden gehanteerd:

andere oorzaken van pulmonale hypertensie, zoals thrombo-emboliën, primaire pulmonale hypertensie, auto-immuun ziekten, hartkleplijden, linker-ventrikelfalen, kyphoscoliose.

- diastolische bloeddruk $>100 \mathrm{mmHg}$.

- angina pectoris, status na hartinfarct.

- nierinsufficiëntie, (serum kreat $>200 \mu \mathrm{mol} .1^{-1}$ ), leverinsufficiëntie (serum transaminasen $>60{\mathrm{U} . \mathrm{I}^{-1}}^{-1}$ en bilirubine $>40 \mu \mathrm{mol} . \mathrm{I}^{-1}$ ).

- insuline-afhankelijke diabetes mellitus.

- claudicatio intermittens klachten.

- cerebro-vasculair accident.

- voorafgaande behandeling met OZT.

- recente $(<4$ weken) periode met luchtweginfectie en/of exacerbatie van het chronisch obstructief Jonglijden.

- maligne aandoening of terminaal stadium van een chronische ziekte.

- gebruik van vaatverwijdende stoffen zoals ACE-remmers, calcium-instroomblokkeerders, $\alpha$-blokkers en nitraten.

\subsection{Onderzoeksprotocol}

Alle metingen werden verricht in rust. Indien de arteriële zuurstofspanning in rust lager was dan $60 \mathrm{mmHg}$, werd tenminste 24 uur vóór het onderzoek zuurstoftoediening per neusslang gestart, om hypoxaemie tijdens uityoering van het onderzoek te voorkomen. De patiënten werden onderzocht in het begin van de middag (start onderzoek 13.00 uur). Op dat moment waren zij nuchter en passief. De onderhoudsmedicatie die de patiënten gebruikten ( $\beta 2$-mimetica, corticosteroïden en theophylline-preparaten) werd op de dag van onderzoek gecontinueerd, met uitzondering van diuretica. 
Fuguur 3.1: Tijdbalk 2-fasen protocol.

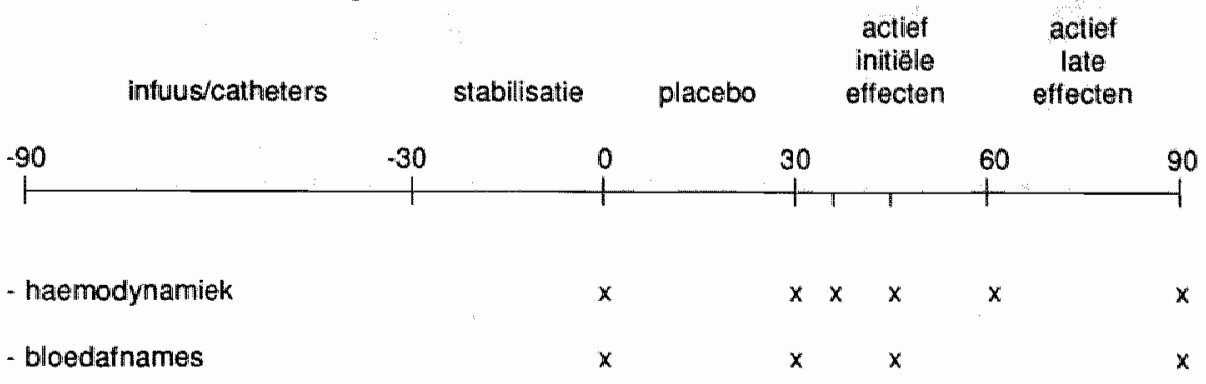

Met de patiënten in halfzittende positie werden een 7-French Swan-Ganz-thermodilutie(Edwards laboratories) en een arteria radialis-catheter (Venflon) ingebracht om de arteriële en pulmonale haemodynamiek vast te leggen en afname van arteriële en gemengd-veneuze bloedmonsters mogelijk te maken.

De volledige uitvoering van het onderzoeksprotocol betekende voor de patiënt een langdurig verblijf ( 3 uur) op de onderzoekskamer van de balansafdeling. De duur van het onderzoek hing samen met de noodzakelijke inloopperiode van het infuus voor het meten van de nierdoorbloeding en met de stabilisatiefase volgend op het inbrengen van de catheters.

Gezien de duur van het onderzoek en de belasting voor de patiënt met een ernstig longlijiden werd gekozen voor een protocol met 2 fasen zoals weergegeven in de tijdbalk in figuur 3.1.

Na het inbrengen van de catheters werd een stabilisatieperiode van een half uur in acht genomen. Vervolgens werden 2 onderzoeksfasen van een half uur doorlopen, respectievelijk de placebofase, waarin controlemetingen plaats vonden, en een actieve fase met metingen $5,15,30$ en 60 minuten na toediening van nifedipine of captopril.

Nifedipine werd toegediend als capsule van $10 \mathrm{mg}$; de vloeistof werd, na leegzuigen wan de capsule, ingeslikt [McAllister 1986]. Captopril werd toegediend als intraveneuze bolus van 2.5 $\mathrm{mg}$, opgelost in $5 \mathrm{ml} \mathrm{NaCl} 0.9 \%$.

\subsection{Methoden}

Het hartritme werd continu elektrocardiografisch geregistreerd. De arteriële en pulmonale drukgolven werden gemeten met behulp van transducers (Statham Instruments) en continu weergegeven door middel van een monitor (Nikon Kohden, model BSM-8500 J/K). Het 
Tabel 3.1: Overzicht van gemeten variabelen.

\begin{tabular}{|c|c|c|}
\hline variabelle & alkorting & eenheid \\
\hline \multicolumn{3}{|l|}{ algemeen } \\
\hline - leeftijd & & jaren \\
\hline - lichaamsoppervlak & BSA & $\mathrm{m}^{2}$ \\
\hline hemoglobine & $\mathrm{Hb}$ & mmolin ${ }^{11}$ \\
\hline hematocriet & Hit & $1.1^{-1}$ \\
\hline - geforceerde expiratoire 1-sec. waarde & FEV & 1 \\
\hline - geforceerde vitale capaciteitt & FVC & 1 \\
\hline \multicolumn{3}{|l|}{ gastransport } \\
\hline - artericle $\mathrm{O}_{2}$-spanning & $\mathrm{PaO}_{2}$ & $\mathrm{mmHg}$ \\
\hline - arteritle $\mathrm{CO}_{2}$-spanning & $\mathrm{PaCO}_{2}$ & $\mathrm{mmHg}$ \\
\hline - arterielle $\mathrm{O}_{2}$-saturatie & $\mathrm{SaO}_{2}$ & 策 \\
\hline - gemengd-veneuze $\mathrm{O}_{2}$-spanning & $\mathrm{PrO}_{2}$ & $\mathrm{mmHg}$ \\
\hline - gemengd-veneuze $\mathrm{O}_{2}$-saturatie & $\mathrm{SwO}_{2}$ & $\%$ \\
\hline \multicolumn{3}{|l|}{ haemodynamiek } \\
\hline - gemiddelde anterielle bloeddruk & MAP & mmHg \\
\hline $\begin{array}{l}\text { gemiddelde pulmonale arteride bloed- } \\
\text { druk }\end{array}$ & MPAP & $\mathrm{mmHg}$ \\
\hline - rechter-atriumdruk & RAP & mmHg. \\
\hline - polmonale capillaire wiggedruk & PCWP & $\mathrm{mmHg}$ \\
\hline - hartfrequentie & HF & slagen.min ${ }^{-1}$ \\
\hline - hartminuutvolume & $\mathrm{CO}$ & $1 \min ^{-1}$ \\
\hline - plasma-flow in de nier & RPF & mlminin \\
\hline
\end{tabular}

hartminuutvolume werd na thermodilutie gemeten met behulp van een hartminuutvolumecomputer (Nikon Kohden, model MCL-4200). Voor het injectaat werd een op ijs gekoelde glucose-5\%-oplossing gebruikt ( $10 \mathrm{ml}$ per injectie). De metingen werden betrouwbaar geacht indien 3 opeenvolgende bepalingen niet meer dan 10\% varieerden [Mackenzie et al 1986]. De bepalingen van de drukken vonden plaats met harthoogte als referentiepunt voor de nulwaarde.

De metingen van de arteriële en gemengd-veneuze bloedgassen en het hemoglobine-gehalte, evenals de hematocriet, vonden plats in het klinisch-chemisch laboratorium (klinischchemici Drs. Mantel, Ir. van Riel). De gaswaarden werden bepaald met behulp van een elektrode (Corning Medical Products). De $\mathrm{Hb}$ en $\mathrm{Ht}$ werden onafhankelijk van elkaar bepaald, gebruik makend van de Elt-8/ds meter (firma Ortho). De metingen van de 
Tabel 3.2* Overzicht van afgeleide variabelen:

\begin{tabular}{|c|c|c|}
\hline afgeleide variabele & afkorting & eenheid \\
\hline \multicolumn{3}{|l|}{ gastransport } \\
\hline - alveolaire partidle $\mathrm{O}_{2}$-gehalte & $\mathrm{PaO}_{2}$ & $\mathrm{mmHg}$ \\
\hline - intrapulmonale shuntfractie & shurnt & 然 \\
\hline - capillair $\mathrm{O}_{2}$-gehalte & $\mathrm{CcO}_{2}$ & ml.(100cc) $)^{-1}$ bloed (vol ow) \\
\hline - arterieel $\mathrm{O}_{2}$-gehalte & $\mathrm{CaO}_{2}$ & ml.(100cc) $)^{-1}$ bloed (vol \%) \\
\hline - gemengd-veneus $\mathrm{O}_{2}$-gehalte & $\mathrm{CwO}_{2}$ & $\mathrm{ml} .(100 \mathrm{cc})^{-1}$ bloed (vol \%) \\
\hline - zuurstoftransport & SOT & ml.min $\min ^{-1}$ \\
\hline zuurstofverbruik & $\mathrm{VO}_{2}$ & $\mathrm{ml} \mathrm{min}^{-1}$ \\
\hline \multicolumn{3}{|l|}{$\begin{array}{l}\text { haemodynamiek } \\
\text { (systemisch, pulmonaal, renaal) }\end{array}$} \\
\hline - perfusiegradièmt in de long & $\mathrm{DP}$ & $\mathrm{mmHg}$ \\
\hline - hartminuutvolume-indlex & $\mathrm{Cl}$ & 1. $\mathrm{min}^{-1} \cdot \mathrm{m}^{-2}$ \\
\hline - slagvolume-index & SVI & ml.slag ${ }^{-1} \cdot \mathrm{m}^{-2}$ \\
\hline - systeem vaatweerstand & SVR & dyne, see $\mathrm{cm}^{-5}$ \\
\hline - pulmonale vaatweerstand & PVR & dyne.sec. $\mathrm{cm}^{-5}$ \\
\hline - linker ventrikel arbeidsindex & LVSWI & $g \cdot m^{-2}$ \\
\hline $\begin{array}{l}\text { rechter ventrikel arbeidsin- } \\
\text { dex }\end{array}$ & RVSWI & g.m. $m^{-2}$ \\
\hline - nierdoorbloeding & RBF & ml.min $\min ^{-1}$ \\
\hline - niervaatweerstand & RVR & dyne.sec. $\mathrm{cm}^{-s}$ \\
\hline
\end{tabular}

longfunctie vonden plaats in het longfunctie-laboratorium (longartsen M. Heysteeg en R. Slingerland).

De variabelen die direct gemeten werden volgens de bovenstaande gegevens zijn samengevat in tabel 3.1, waarin ook de gehanteerde afkortingen en eenheden weergegeven zijn. Van deze gemeten gegevens werd gebruik gemaakt om een aantal afgeleide variabelen te berekenen, die zijn samengevat in tabel 3.2. De gebruikte formules staan vermeld in tabel 3.3. Het lichaamsoppervlak werd verkregen door gebruik te maken van een nomogram voor lengte en gewicht.

\subsection{Specifieke laboratoriumbepalingen}

De bepalingen betroffen de stoffen noradrenaline, adrenaline, dopamine, renine, angiotensine $\mathrm{II}$, aldosteron, angiotensine converting enzyme, het atriale natriuretische peptide en 
Tabel 3.3: Gebruikte formules (eenheden van de variabelen staan alle wermeld in de tabellen 3.1 en 3.2).

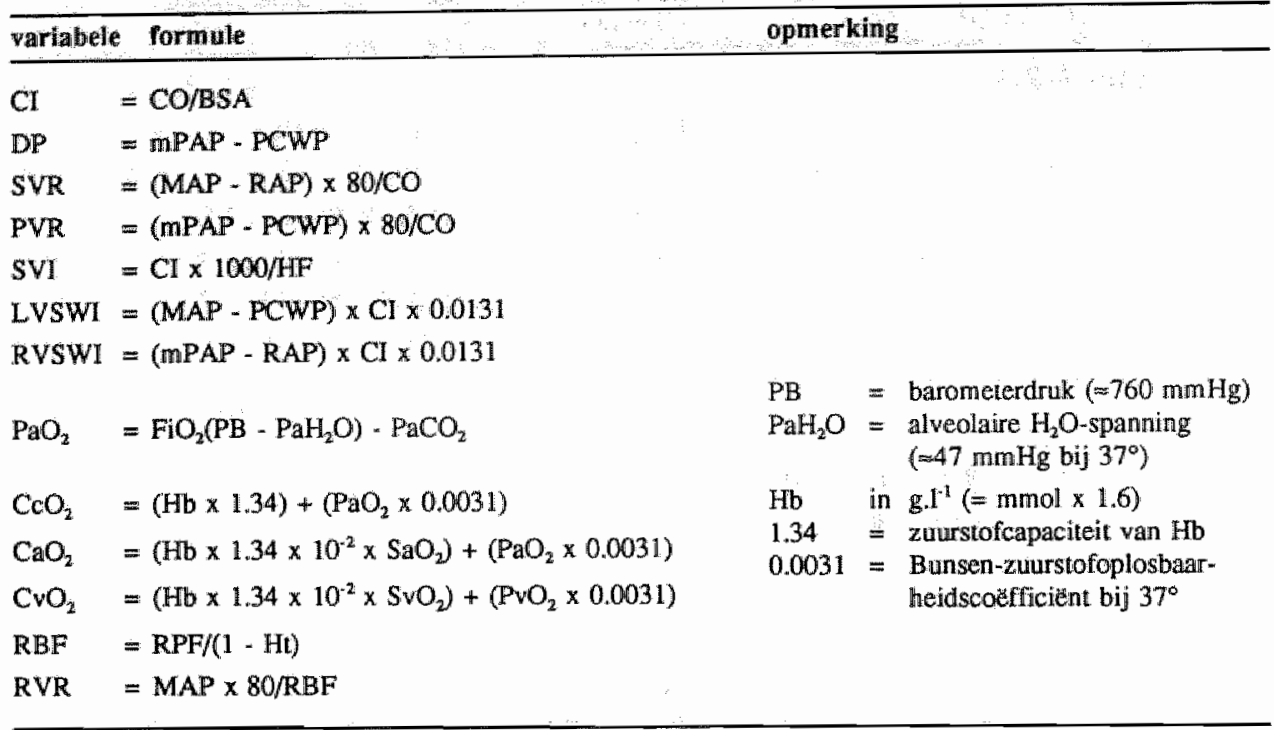

erythropoietine. Het hiervoor benodigde bloed werd zowel gemengd-veneus als arterieel afgenomen. Vóór het afnemen van de monsters werd steeds $3 \mathrm{cc}$ uit de arteriële en arteria pulmonalislijn opgezogen om interferentie door injectaat of flushing te voorkomen. De normaalwaarden zijn samengevat in tabel 3.4 .

\subsubsection{Catecholamines (noradrenaline, adrenaline, dopamine)}

Bloed werd opgevangen, via de catheter of venflon, in ijsgekoelde buizen met glutathion en heparine. Na centrifugeren werd het plasma bewaard bij $-70^{\circ}$. De plasmawaarden werden bepaald door middel van de radio-enzymatische methode [Peuler en Johnson 1977], gebruik makend van catechol-o-methyl-transferase als enzym en S-adenosylmethionine als radioactieve methyldonor. High-performance liquid chromatography werd gebruikt om de drie componenten (adrenaline, noradrenaline en dopamine) van elkaar te scheiden. De inter- en intra-assay variabiliteit bedroegen $8 \%$ en $6 \%$ voor het noradrenaline en adrenaline, terwijl de waarden voor het dopamine $12 \%$ en $9 \%$ waren. 
Tabel 3.4: Hormoonbepalingen met normal waarden:

\begin{tabular}{|c|c|c|c|}
\hline hormoonbepalingen & afkorting & eenheid & normaallwaarde \\
\hline - noradrenaline & & nmol. ${ }^{+1}$ & $0.5-3.0$ \\
\hline - adrenaline & & nmol..." & $0.1-1.0$ \\
\hline - dopamine & & nmol. $\left.\right|^{-1}$ & $0-0.8$ \\
\hline - renime & APRC & $\mathrm{mE} \mathrm{I}^{-1}$ & $15-40$ \\
\hline - angiotensine II & A III & pmol..." & $<25$ \\
\hline - aldosteron & & pmol. $\|^{41}$ & $60 \cdot 600$ \\
\hline $\begin{array}{l}\text { angiotensine converting-enzy- } \\
\text { me }\end{array}$ & $\mathrm{ACE}$ & $\mathrm{E} \cdot \mathrm{ml}^{-1}$ & $6-20$ \\
\hline - erythropoietine & EPO & $\mathrm{mE}_{\mathrm{s}} \mathrm{ml}^{-1}$ & $0.9-10$ \\
\hline - atriaal natriuretisch peptide & ANP & pmol. $\mathrm{H}^{-1}$ & $<36$ \\
\hline
\end{tabular}

\subsubsection{Actieve plasma-renineconcentratie (APRC)}

Bloed werd opgevangen in ijsgekoelde buizen met EDTA. Na centrifugeren werd het plasma bewaard bij $-70^{\circ}$. De bepaling van de actieve plasma-renineconcentratie werd verricht met behulp van schapensubstraat als exogeen substraat [Skinner et al 1975]. De bepalingen vonden plaats bij $\mathrm{pH}$ 4.5. Vervolgens werd radio-immuno-assay verricht op de hoeveelheid gevormde angiotensine I. De inter- en intra-assay variabiliteit bedroegen $14 \%$ en $8 \%$.

\subsubsection{Angiotensine II}

Afname van bloed in ijsgekoelde buizen met EDTA, 0-fenantroline en captopril. Na centrifugeren werd het bloed bewaard bij $-70^{\circ}$. De bepaling werd verricht met behulp van een radio-immunoassay, gebruik makend van een specifiek konijnen-antiserum en van een standaard angiotensine II (Cambridge Research Chemicals). De inter- en intra-assay variabiliteit bedroegen $11 \%$ en $6 \%$.

\subsubsection{Aldosteron}

Afname van ongestuwd bloed in ijsgekoelde buizen met EDTA. Na centrifugeren werd het bloed bewaard bij $-70^{\circ}$. De bepaling werd verricht met behulp van een immuno-assay, gebruik makend van met antiserum gecoate buizen (Diagnostic Products Corporation) en met $I^{125}$-gelabeld antigeen [Walsh et al 1979 ]. De inter- en intra-assay variabiliteit bedroegen $8 \%$ en $4 \%$. 


\subsubsection{Anglotensine converting enzyme}

Afname van ongestuwd bloed in ijsgekoelde buizen en opslag bij $-70^{\circ}$, na centrifugeren. Bij de bepaling werd gebruik gemaakt van een colorimetrische methode [Kasahara en Ashihara 1981]. Als substraat werd het para-hydroxybenzoyl-glycyl-L-histidyl-L-leucine gebruikt, dat ongezet word in quinoneimine (Kit van Fujirebio, Japan). De inter- en intra-assay variabiliteit bedroegen $7 \%$ en $4 \%$.

\subsubsection{Atriaal natriuretisch peptide}

Afname van bloed, ongestuwd, in ijsgekoelde buizen; het plasma werd die na centrifugeren opgeslagen bij $-70^{\circ}$. De meting van het ANP vondt plaats door middel van een directe radioimmunologische assay na extractie over een Sep-Pak 18 kolom (Immunotechnology Service, Wijchen). De inter- en intra-assay variabiliteit bedroegen $10 \%$ en $6 \%$.

\subsubsection{Erythropoietine}

Afname van ongestuwd bloed in ijsgekoelde buizen. De bepaling van het serum erythropoietine werd verricht met behulp van een sandwich radio-immunoassay met monoclonale antilîchamen [Wognum et al 1988].

\subsection{Renale plasmastroom}

Voor de bepaling van RPF werd gebruik gemaakt van $I^{125}$-Hippuran. Na een oplaad dosis van $0.3-0.4 \mu \mathrm{Ci} / \mathrm{kg}$ Hippuran vond een continue infusie plaats met $0.2 \mu \mathrm{Ci} / \mathrm{min}$ om een evenwichtsituatie te bereiken. De klaring van de stof werd berekend met behulp van plasmamonsters. Het gemiddeld aantal counts uit de monsters in verhouding tot de standaard hoeveelheid counts uit de oorspronkelijke oplossing leverde de infusieklaring op. Voor het berekenen werd uitgegaan van een extractie-ratio van $75 \%$ [de Leeuw 1978].

\subsection{Statistische methoden}

De gegevens worden gepresenteerd als gemiddelden \pm standaard-deviatie. De correlaties tussen de verschillende variabelen in de uitgangssituatie (vóór toediening van de 
vaatverwijdende stoffen) worden getoond met behulp wan lineaire regressieanalyse. Vergelijkingen tussen groepen vinden plaats met behulp van de t-test voor ongepaarde data. De effecten van vaatverwijdende stoffen op de verschillende parameters in de tijd worden gepresenteerd met behulp van variantie-analyse voor herhaalde metingen, en gebruik makend van de Bonferroni-correctie Wallenstein et al 1980].

Analyse van de variabelen die de overleving beïnvloeden vindt plaats met behulp van het Cox-proportional-hazard-model. De overlevingscurves worden berekend en gepresenteerd volgens de Kaplan-Meier-methode [Kaplan en Meier 1958].

Alle berekeningen en curves werden verkregen met behulp van een personal computer statistiekprogramma (Stata inc., Los Angeles). 


\section{$4 \quad$ Resultaten van het onderzoek}

\subsection{Inleiding}

In totaal werd bij 40 patiënten het basale onderzoek verricht, zoals is beschreven in hoofdstuk 3 . Het betrof 12 vrouwen en 28 mannen, met een gemiddelde leeftijd van 67 jaar. Tien patiënten waren jonger dan 60 jaar en 4 waren ouder dan 75 jaar. Bij allen werden gegevens betreffende de centrale haemodynamiek en gaswisseling verkregen. Bij de laatste 14 patiënten werden de basalebepalingen uitgebreid met gelijktijdige metingen van de nierdoorbloeding en de (neuro-)hormonen. Verhogingen van het $\mathrm{Hb}$-gehalte en de $\mathrm{Ht}$ werden vastgesteld bij 16 van de 40 patiënten. De algemene gegevens zijn samengevat in tabel 4.1. In deze en de volgende tabellen zijn de normaalwaarden van de bepalingen, indien van toepassing, vermeld. De resultaten van de bepalingen van de (neuro-)hormonen worden vergeleken met de gegevens van een, voor leeftijd en geslacht gematchte, controlegroep uit ons laboratorium.

De beschrijving van de resultaten met hun verbanden, wordt apart gepresenteerd voor de haemodynamische variabelen en voor de parameters van de gaswisseling. Vervolgens worden de onderlinge relaties tussen deze circulatoire en respiratoire variabelen besproken,

Tabel 4.1: Basale patièntengegevens in 40 patiënten.

\begin{tabular}{|c|c|c|c|}
\hline variabule & eenheid & waarde & normaal \\
\hline leeftijid & (jaren) & $67 \pm 9$ & \\
\hline $\mathrm{Hb}$ & $\left(\mathrm{mmol} . \mathrm{I}^{\mathrm{r}}\right)$ & $10.2 \pm 1.0$ & $8.5-11.0$ \\
\hline $\mathrm{Hit}$ & $\left(1.1^{-1}\right)$ & $0.50 \pm 0.05$ & $0.40-0.51$ \\
\hline $\mathrm{FEV}_{1}$ & (l) & $0.87 \pm 0.25$ & "* \\
\hline $\mathrm{FEV}, / \mathrm{FVC}$ & $(\%)$ & $36 \pm 10$ & $>60$ \\
\hline $\mathrm{PaO}_{2}$ & $(\mathrm{mmHg})$ & $73 \pm 19$ & $>60$ \\
\hline $\mathrm{PvO}_{2}$ & (mmHg) & $38 \pm 4$ & $35-40$ \\
\hline $\mathrm{PaCO}_{2}$ & $(\mathrm{mmHg})$ & $46 \pm 8$ & $35-45$ \\
\hline $\mathrm{SaO}_{2}$ & $(\%)$ & $93 \pm 4$ & $>90$ \\
\hline $\mathrm{FiO}_{2}$ & $(\%)$ & $24 \pm 3$ & $21^{\circ}$ \\
\hline $\mathrm{pH}$ & & $7.38 \pm 0.02$ & $7.35-7.45$ \\
\hline $\begin{array}{l}\text { Bij kame } \\
\text { afhankel }\end{array}$ & de leefuijd & & \\
\hline
\end{tabular}


evenals de analyse van subgroepen met pulmonale hypertensie respectievelijk hypercapnie. Het hoofdstuk wordt besloten met een algemene bespreking.

\subsection{Gegevens met betrekking tot de circulatie}

\subsubsection{Uitgangswaarden}

De waarden van de systemische en pulmonale haemodynamische variabelen staan vermeld in tabel 4.2 .

Bij 20 van de 40 patiènten werd pulmonale hypertensie in rust vastgesteld (mPAP $>20$ mmHg). Bij 15 patiënten was er sprake van een milde verhoging (mPAP tussen 20 en 30 $\mathrm{mmHg}$ ), terwijl bij 4 patiënten de mPAP tussen 30 en $40 \mathrm{mmHg}$ lag, en bij 1 patiënt een waarde boven de $40 \mathrm{mmHg}$ werd vastgesteld.

De cardiale vullingsdrukken, gemeten aan de RAP en PCWP, lieten normale waarden zien, evenals de hartfrequentie. De hartminuutvolume-index bleek bij 3 patiënten laag te zijn, namelijk 2.0 en 2.1 (2x) $\operatorname{lmmin}^{-1} \cdot \mathrm{m}^{-2}$ (normaal $2.5-4.0$ ), terwij]. bij 4 patiënten de SV-index

Tabel 4.2: Haemodynamiek- en gastransportgegevens bij 40 patie̋nten.

\begin{tabular}{|c|c|c|c|}
\hline variabele & eenheid & waarde & normaalwaarde \\
\hline MAP & $(\mathrm{mmHg})$ & $92 \pm 13$ & $80-100$ \\
\hline mPAP & $(\mathrm{mmHg})$ & $22 \pm 8$ & $\leq 20$ \\
\hline RAP & $(\mathrm{mmH} H)$ & $2 \pm 3$ & $0-8$ \\
\hline PCWP & $(\mathrm{mmHg})$ & $6 \pm 3$ & $5 \cdot 15$ \\
\hline perfusiegradient & $(\mathrm{mmHg})$ & $16 \pm 7$ & $5 \cdot 15$ \\
\hline $\mathrm{HF}^{\prime \prime}$ & (slagen.min ${ }^{-1}$ ) & $88 \pm 14$ & $<100$ \\
\hline $\mathrm{CO}$ & $\left(1 . \mathrm{min}^{-1}\right)$ & $5.7 \pm 1.4$ & $4.0-7.0$ \\
\hline SV & (mllslag $\left.{ }^{\Perp}\right)$ & $66 \pm 18$ & $60-70$ \\
\hline SVR & (dyne.sec. $\mathrm{cm}^{-5}$ ) & $1333 \pm 353$ & $<\mathbb{1 2 0 0}$ \\
\hline PVR & $\left(\right.$ dyne, sec, $\mathrm{cm}^{-5}$ ) & $233 \pm 117$ & $<120$ \\
\hline LVSWI & $\left(\mathrm{g} \cdot \mathrm{m}^{-2}\right)$ & $45 \pm 13$ & $>40$ \\
\hline RVSWI & $\left(g, m^{-2}\right)$ & $11 \pm 5$ & $8-12$ \\
\hline shunt & $(\%)$ & $23 \pm 10$ & $<10$ \\
\hline SOT & $\left(\mathrm{mll} \mathrm{min}^{-1}\right)$ & $1179 \pm 333$ & $>1000$ \\
\hline $\mathrm{VO}_{2}$ & $\left(\mathrm{mll} \cdot \mathrm{min}^{-1}\right)$ & $293 \pm 86$ & $>300$ \\
\hline
\end{tabular}


Tabel 4.3: Hormonale bepalingen bij 14 patisnuen met ernstig obstructief longlijden. (Verschillen tussen de 2 lokalisaties, arterieel en gemengd-weneus, berekend volgens gepaarde-(-test).

\begin{tabular}{|c|c|c|c|c|c|}
\hline hormoon & eenheid & arterieel & $\begin{array}{l}\text { gemengd- } \\
\text { veneus }\end{array}$ & $\mathrm{p}$ & $\begin{array}{c}\text { normaal } \\
\text { (arterieel) }\end{array}$ \\
\hline noradrenaline & $\left.\left(\text { (nmol. }^{-1}\right)^{-1}\right)$ & $2.62 \pm 1.27$ & $2.86 \pm 1.39$ & 0.05 & $0.50-3.00$ \\
\hline adrenaline & $\left(\right.$ nmol. $\left.1^{-1}\right)$ & $0.36 \pm 0.22$ & $0.43 \pm 0.28$ & $0.05<p<0.10$ & $0.10 \cdot 1.00$ \\
\hline dopamine & $\left(\mathrm{nmol}, \mathrm{l}^{-1}\right)$ & $0.35 \pm 0.25$ & $0.42 \pm 0.23$ & $0.05<p<0.10$ & $<0.80$ \\
\hline renine & $\left.\left(\mathrm{mE}^{-1}\right)^{-4}\right)$ & $88 \pm 65$ & $79 \pm 57$ & $<0.05$ & $15-40$ \\
\hline aldosteron & $\left(\right.$ pmol. $\left.^{-1}\right)$ & $523 \pm 165$ & $544 \pm 144$ & NS & $60-600$ \\
\hline angiotensine II & $\left(\right.$ prnol..$\left.^{-1}\right)$ & $15.5 \pm 7.6$ & $12.6 \pm 6.1$ & 0.05 & $<25$ \\
\hline ANP & $\left(\mathrm{pmoll}^{-1}\right)$ & $40 \pm 20$ & $41 \pm 17$ & NS & $<36$ \\
\hline erythropoietine & $\left(\mathrm{mE} \mathrm{ml}^{-\mathrm{l}}\right)$ & $4.3 \pm 3.6$ & $4.3 \pm 3.8$ & NS & $0.9-10$ \\
\hline
\end{tabular}

laag was, respectievelijk 19, 21, 24 en $25 \mathrm{ml} . \mathrm{slag}^{-1} \cdot \mathrm{m}^{-2}$ (normaal $30-45$ ). Conform de studie-opzet werd geen uitgesproken hypertensie vastgesteld in onze onderzoeksgroep. De veneuze bijmenging, berekend volgens de Berggreen-formule, leverde sterk wisselende waarden op, variërend van 6 tot $46 \%$, normaliter kleiner dan $10 \%$.

De bevindingen met betrekking tot de hormonale bepalingen en de renal plasma flow zijn samengevat in tabel 4.3 en 4.4 .

Bij de evaluatie van de catecholaminen valt een betrekkelijk consistent patroon op, namelijk hogere waarden in het gemengd-veneuze bloed ten opzichte van arteriële waarden. Indien

Tabel 4.4: Nierdoorbloeding- en haemodynamiekgegevens bij 14 patienten met ernstig obstructief longlijden.

\begin{tabular}{|c|c|c|c|}
\hline variabele & eenheid & waarde & normaalwaarde \\
\hline RPF & $\left(\mathrm{ml} \mathrm{min}^{-1}\right)$ & $308 \pm 80$ & $300-900$ \\
\hline $\mathrm{RBF}$ & $\left(\mathrm{ml} . \mathrm{min}^{-1}\right)$ & $605 \pm 176$ & $500-1500$ \\
\hline RVR & $\left(\right.$ dyne. sec $\left.\mathrm{cm}^{-5}\right)$ & $13440 \pm 5315$ & $5000-16000$ \\
\hline MAP & $(\mathrm{mmHg})$ & $92 \pm 13$ & $80-100$ \\
\hline PCWP & $(\mathrm{mmHg})$ & $7 \pm 4$ & $5-15$ \\
\hline HF & (slagen $\min ^{-1}$ ) & $89 \pm 17$ & $<100$ \\
\hline $\mathrm{CI}$ & $\left(1 . \mathrm{min}^{4} \cdot \mathrm{m}^{2}\right)$ & $3.45 \pm 0.96$ & $2.5-4.0$ \\
\hline SVR & $\left(\right.$ dyne sec $\left.\mathrm{cm}^{-5}\right)$ & $1322 \pm 459$ & $<1200$ \\
\hline
\end{tabular}


Figuur 4:1: Arteriele en gemengd-venewze adrenalinespiegels bij 14 patiunten.

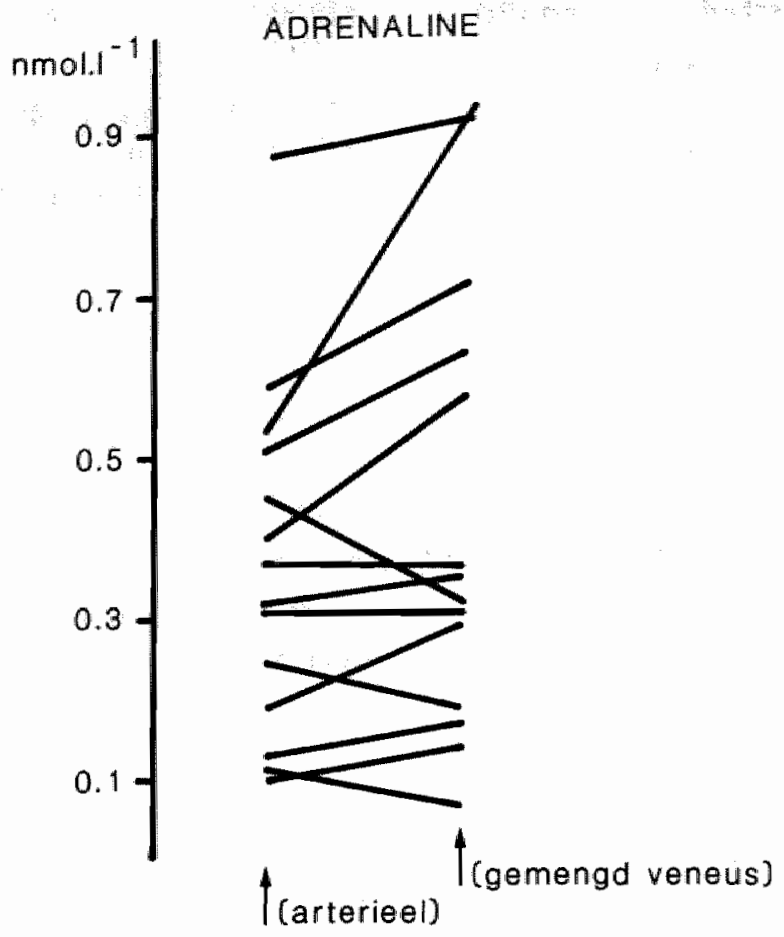

de gepaarde gegevens nader worden bezien, blijkt deze trend zich vooral bij de hogere waarden voor te doen. Als voorbeeld zijn de data voor de adrenaline-waarden weergegeven in figuur 4.1 .

Bij de analyse van het RAAS springt de fors verhoogde waarde van het renine naar voren, in de aanwezigheid van gemiddeld normale waarden voor aldosteron en angiotensine II. Het renine was meer dan twee maal de norm (arterieel $88 \pm 65 \mathrm{mU.l}^{-1}$, normaal $<40$ ) en het verschil ten opzicht van de gematchte controlegroep was groot $\left(88 \pm 65\right.$ vs $15 \pm 3 \mathrm{mU}^{-1}$, $\mathrm{p}<0.005$ ). De waarden voor het ANP bleken licht verhoogd, zonder duidelijke verschillen in de arteriële en gemengd-veneuze fase. Het erythropoietinegehalte was volledig normaal. De RPF als maat voor de nierdoorbloeding is aan de lage kant (gemiddeld $308 \pm 80$ $\mathrm{ml} . \mathrm{min}^{-1}$, spreiding $188-465$ ) voor de leeftijd, indien vergeleken wordt met voor teeftijd en geslacht gematchte patiènten in een controlegroep uit ons laboratorium. 


\subsubsection{Verbanden}

Zoals te verwachten, bleken de vaatweerstanden in het systemische en renale vaatbed gerelateerd te zijn aan de leeftijd (figuur 4.2 en 4.3). Met het oplopen van de leeftijd daalden de RPF en RBF (RBF ws leeftijd: $p<0.05$ en $r=-0.66$; RPF vs leeftijd: $p<0.05$ en $\mathrm{r}=-0.60$ ). Deze data stemmen overeen met gegevens uit het hypertensie-onderzoek [De Leeuw et al 1978].

Ten gevolge van de correlatie leeftijd - SVR werden ook verbanden vastgesteld tussen leeftijd en aan de SVR gerelateerde variabelen als de SVI en SOT.

Behalve een afname van de nierdoorstroming met de leeftijd, werd ook een daling van de Ht vastgesteld (figuur 4.4), een waarneming die reeds bekend is uit een grote hypertensietrial [Staessen 1990]. De leeftijd toonde overigens geen duidelijk verband met de neuroendocriene bepalingen.

Opvallend was het verband van de rechter-atriumdruk met het Hb en $\mathrm{Ht}$ (Hb vs RAP: $\mathrm{p}<$ 0.001 en $\mathrm{r}=-0.51$; Ht vs RAP: $\mathrm{p}<0.05$ en $\mathrm{r}=-0.36$ ). Het verband met het $\mathrm{Hb}$ is weergegeven in figuur 4.5. Een hoog $\mathrm{Hb}$-gehalte en een lage RAP suggereren

Figuur 4.2: Relatie tussen leeftijd en systemische vaatweerstand.

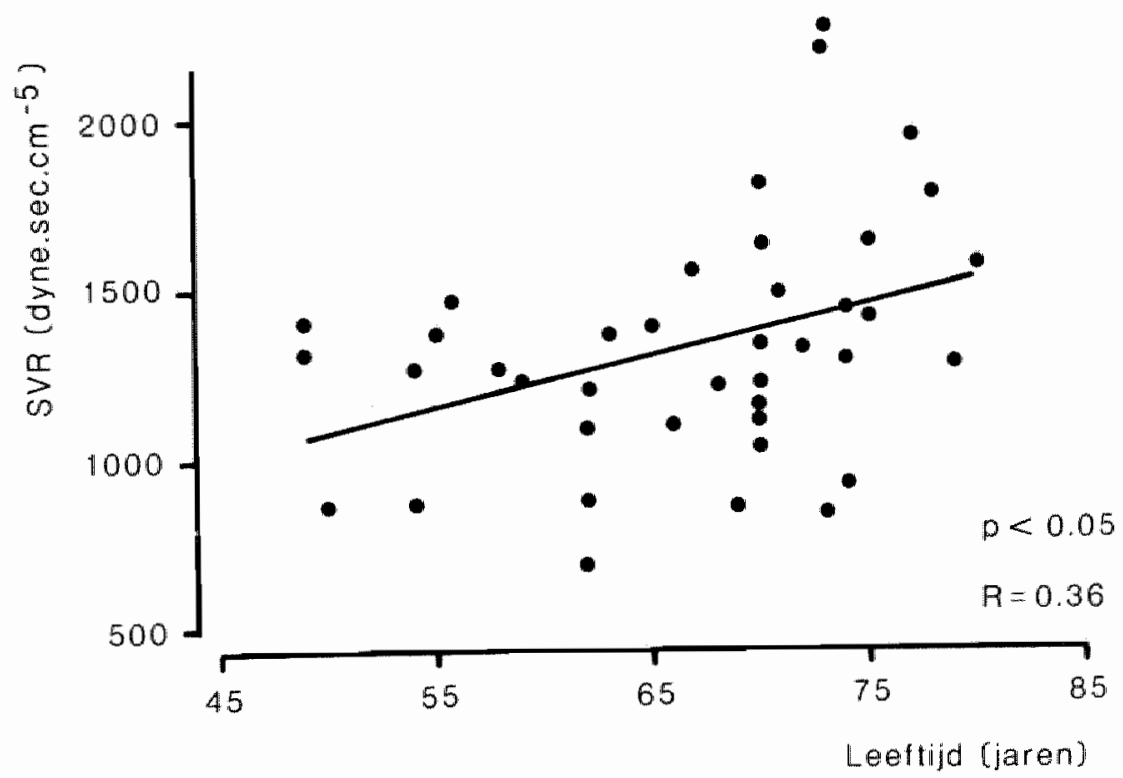


Figutur 4.3: Relatie tussen leefijd on renale vaatweerstand.

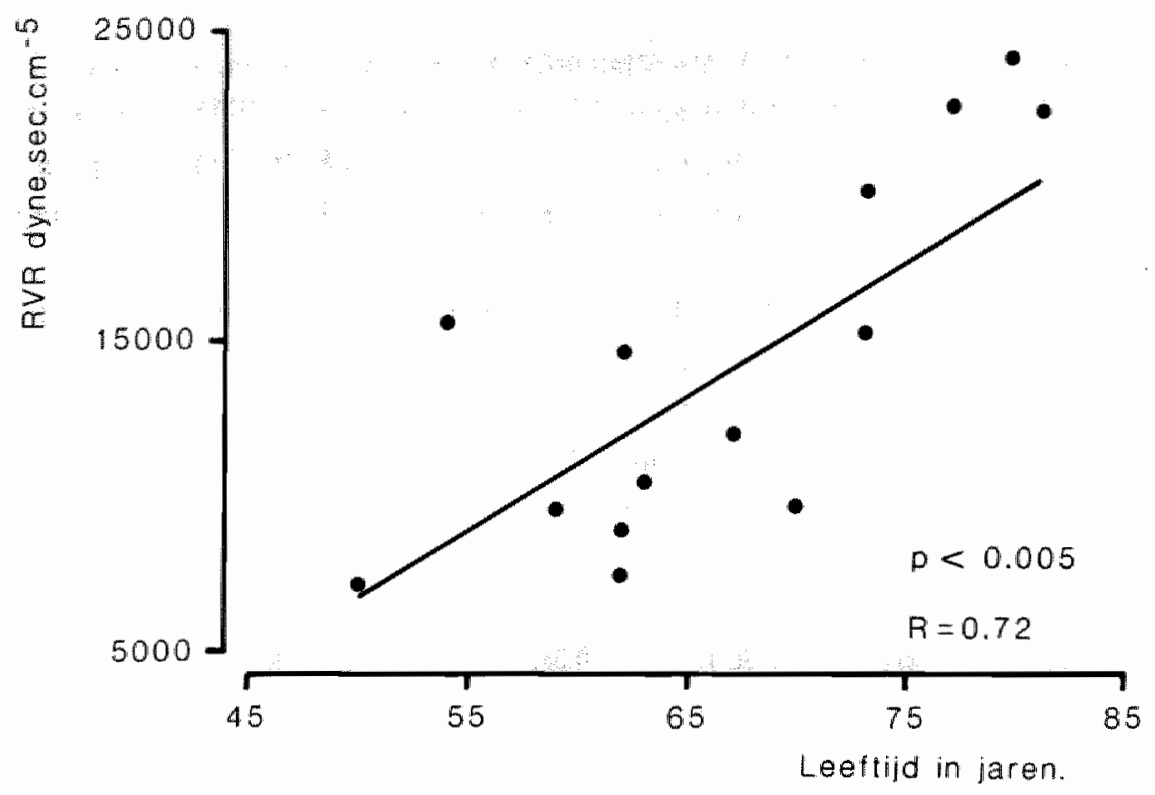

Figuur 4.4: Leeftijd in relatie tot de hematocriet.

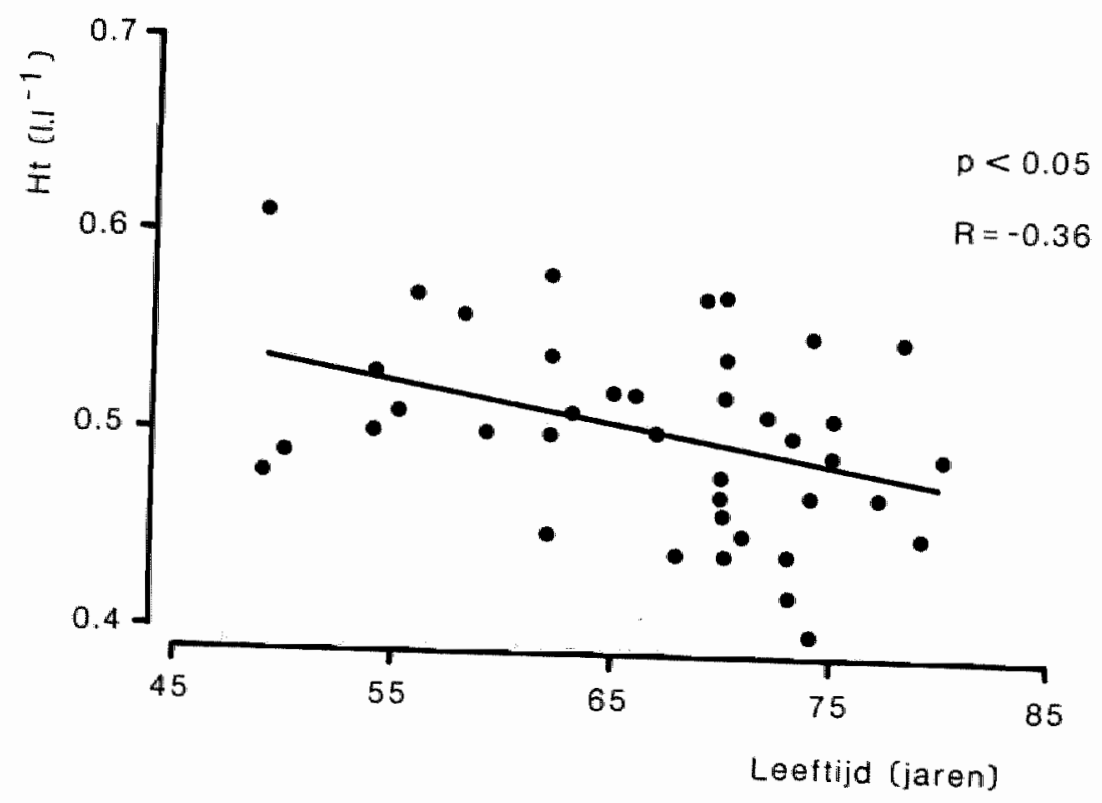


Figuur 4.5: Het hemoglobinegehalne in relatie tot de rechter-atriumdruk.

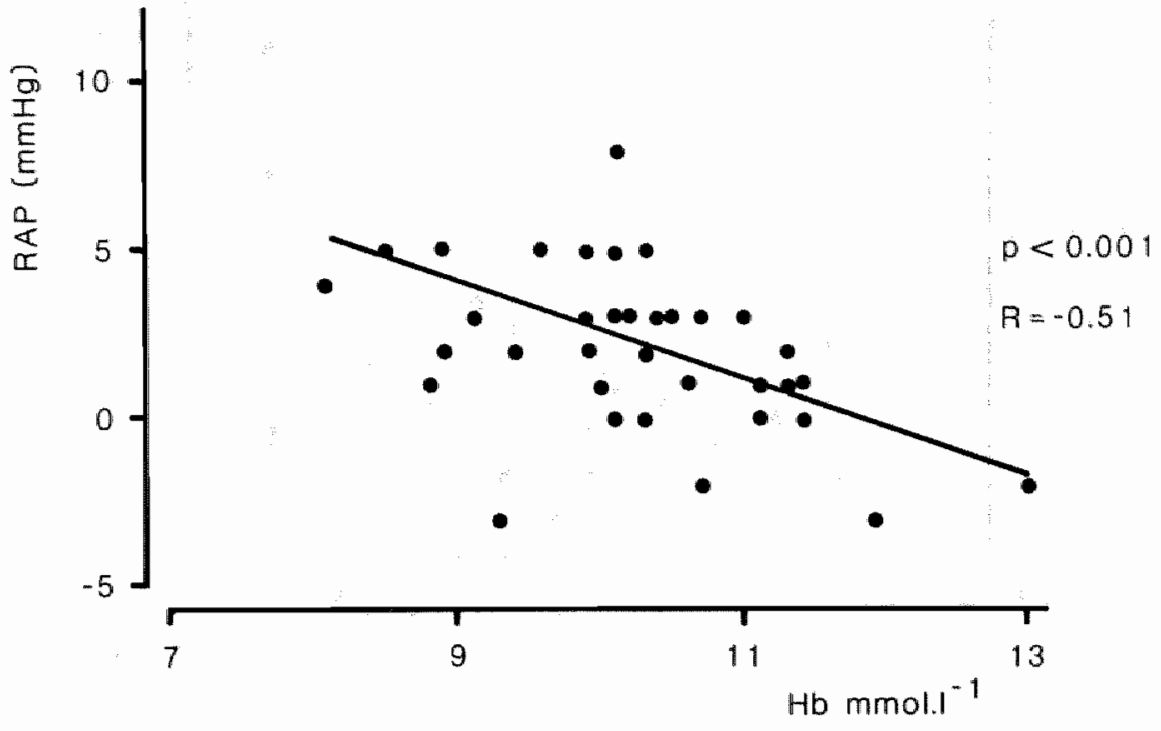

hemoconcentratie of verminderde veneuze terugvloed. [Guyton 1957]. Een duidelijke relatie tussen $\mathrm{Hb}$ en wiggedruk kon echter niet vastgesteld worden ( $p=0.80)$. De RAP hield wel verband met de wiggedruk als maat voor de vullingstoestand (RAP vs wiggedruk: $p=0.01$ en $r=0.37$ ).

In tegenstelling tot de RAP bleek de mPAP niet duidelijk gerelateerd aan het $\mathrm{Hb}$ of $\mathrm{Ht}$. De mPAP was wel gerelateerd aan de overige haemodynamische variabelen, ${ }^{2}$ oals weergegeven in tabel 4.5 en figuur 4.6. De mPAP bleek zowel aan de atriumdruk en de wiggedruk

Tabel 4.5: Correlaties tussen de mPAP en andere haemodynamische variabelen.

\begin{tabular}{lcc}
\hline variabele & \multicolumn{1}{c}{$\mathbf{p}$} & $\mathbf{r}$ \\
\hline mPAP - PCWP & $<0.05$ & 0.39 \\
mPAP - RAP & $<0.005$ & 0.47 \\
mPAP - MAP & $<0.005$ & 0.47 \\
mPAP - CO & NS & 0.15 \\
\hline
\end{tabular}


Figum 4.6: De MAP' in relatie tol de mPAP.

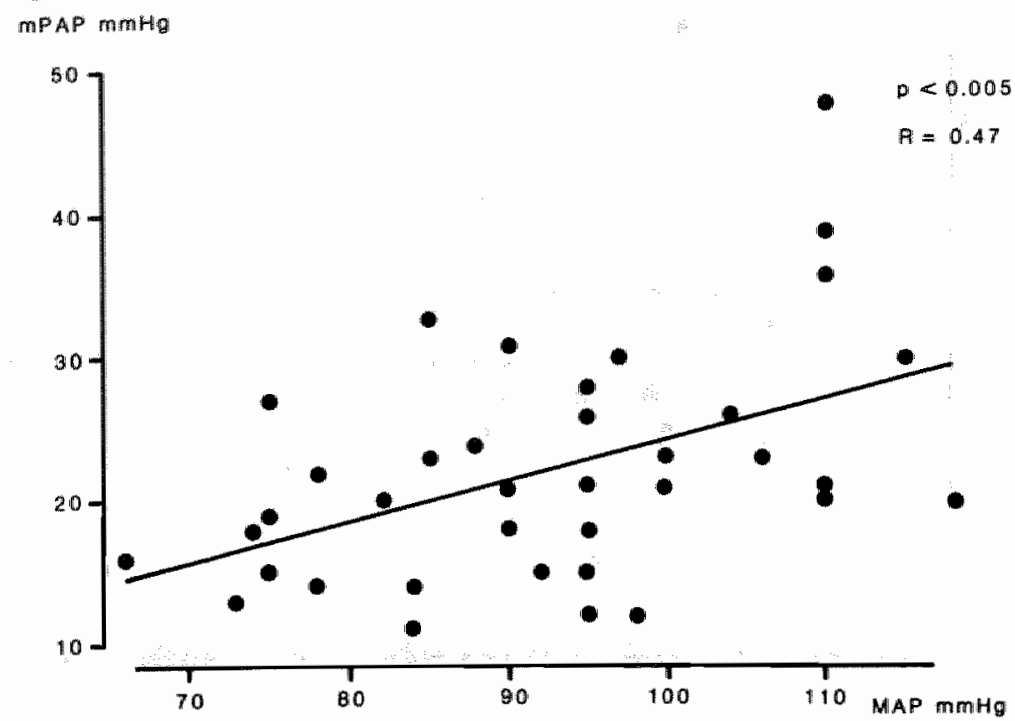

gerelateerd, als aan de bloeddruk. Daarbij bleek de laatste variabele het meest van belang te zijn.

De parameters van de centrale haemodynamiek bleken weinig gerelateerd aan de nierdoorbloeding, met uitzondering van een verband tussen de RAP en de RVR ( $p<0.05$ en $r=0.53)$ en de te verwachten relatie tussen CO en RBF ( $p<0.05$ en $r=0.62)$. Er werden echter geen verbanden vastgesteld tussen parameters van de longcirculatie (mPAP, PVR) en de RPF of RVR. Ook de neuro-endocriene hormonen, zowel de catecholaminen als thet RAAS, toonden geen verband met de centrale haemodynamiek. De overige hormonen of peptiden (erytliropoietine, ANP) toonden ook geen verband met de parameters van de longcirculatie respectievelijk de systemische haemodynamiek, met name de rechteratriumdruk (ANP vs RAP: $\mathrm{p}=0.59$ ). Dit in tegenstelling tot patiënten met linkerventrikelfalen, waar de ANP-waarde correleert met de RAP [Raine et al 1986].

De bloeddruk bleek te correleren met het arteriële noradrenalinegehalte $(p<0.05$ ), verder werden geen bijzonderheden vastgesteld. Ten aanzien van de nierdoorbloeding vielen slechts de relatie op met het veneuze A II. $(p=0.02, r=-0.70)$ en een zwak verband tussen de RPF en het veneuze renine $(p=0.10)$, terwijl geen verband met de arteriële hormoonbepalingen kon worden vastgesteld. 
Figuur 4.7: Relatie ussen leefüjd en FEV.

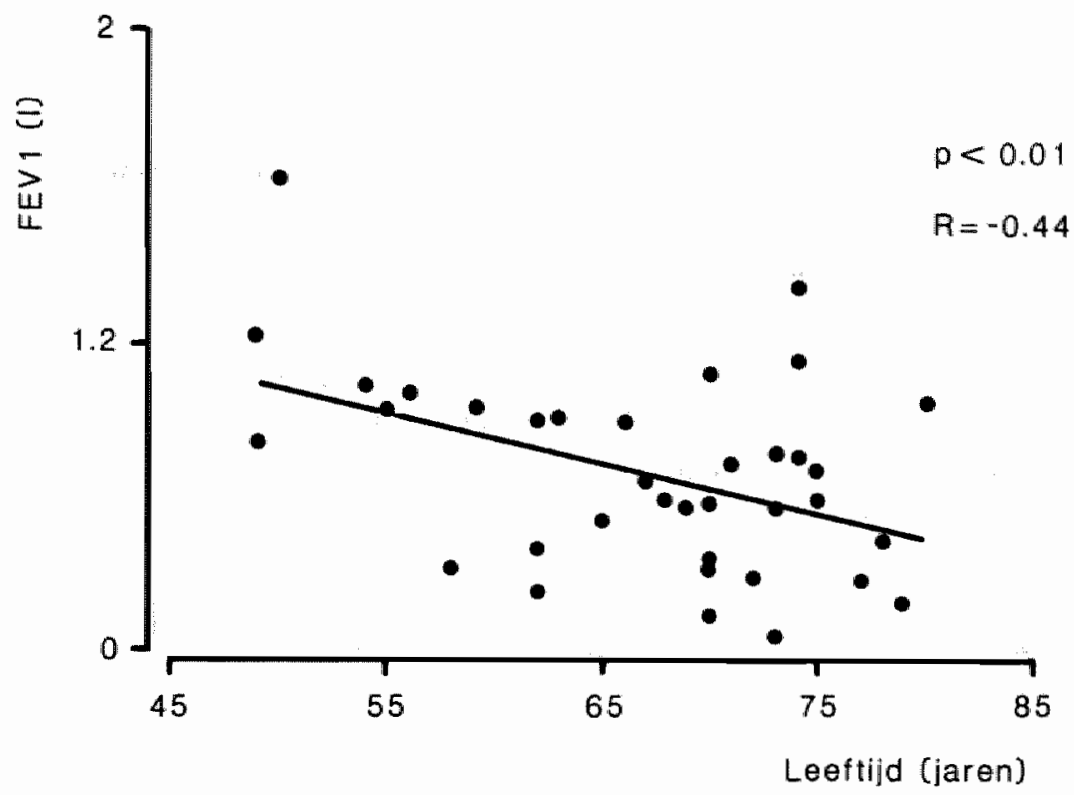

\subsection{Gegevens met betrekking tot de gaswisseling}

De basale gegevens over de gaswaarden en de longfunctieparameters staan vermeld in de tabellen 4.1 en 4.2. De longfunctiegegevens illustreren de ernst van het obstructief longlijden; bij 23 van de 40 patiënten was de FEV lager dan 1 liter. Overeenkomstig de studieopzet werd normoxie in rust vastgesteld, terwijl een lichte hypercapnie aanwezig was. Bij 5 patiënten gelukte het niet een arterièle verzadiging groter dan $90 \%$ te bereiken, ondanks zuurstoftoediening.

Met betrekking tot de analyse wan de parameters van de gaswisseling valt allereerst het verband op tussen de leeftijd en de $\mathrm{FEV}_{1}$ (figuur 4.7). Daarentegen bleek de $\mathrm{FEV} / \mathrm{FVC}$ als maat voor de luchtwegobstructie niet te zijn gerelateerd aan de $\mathrm{Ht}$, de leeftijd of de gaswaarden. Wel bleken $\mathrm{Hb}$ en $\mathrm{Ht}$ te zijn gerelateerd aan de gemengd-veneuze zuurstofspanning ( $\mathrm{Hb}$ vs $\mathrm{PvO}_{2}: \mathrm{p}<0.05$ en $\mathrm{r}=0.36$; $\mathrm{Ht}$ vs $\mathrm{PvO}_{2}: \mathrm{p}<0.005$ en $\mathrm{r}=0.44$ ). De directe relatie geeft waarschijnlijk het zuurstoftransporterend vermogen weer van het $\mathrm{Hb}_{\text {. }}$ 


\subsection{Relaties tussen de circulatoire en respiratoire variabelen}

\subsubsection{Longfunctie en haemodynamiek}

De expiratoire ến-seconde-waarde bleek gerelateerd te zijn aan de systemische en renale haemodynamiek. De FEV, toonde een correlatie met de SVR $(\mathrm{p}<0.05, \mathrm{r}=0.39$, figuur 4.8) en aan SVR gerelateerde variabelen als de SVI, LVSWI, SOT en $\mathrm{VO}_{2}$ (figuur 4.9).

De gegevens ten aanzien van de renale haemodynamiek zijn opvallend. De FEV ${ }_{1}$ blijkt sterk gerelateerd aan de nierdoorbloeding (tabel 4.6, figuur 4.10). Gezien de invloed van de leeftijd op zowel de FEV 1 als de RPF, werd stapsgewijze multiple regressie verricht op de factoren die aan de RPF gerelateerd waren. Daarin bleken de leeftijd en FEV, een onafhankelijke significante invloed op de RPF uit te oefenen, waarbij vooral de sterke invloed van de $\mathrm{FEV}_{1}$ op de nierdoorstroming opvalt. De $\mathrm{FEV} / \mathrm{FVC}$ als maat voor de bronchusobstructie, toonde daarentegen geen duidelijk verband met de nierdoorstroming of vatweerstand $\left(\mathrm{FEV}_{1} / \mathrm{FVC}\right.$ vs RPF: $\left.\mathrm{p}=0.16\right)$.

Figuur 4.8: Relatic tussen FEV, en systemische vaatweerstand.

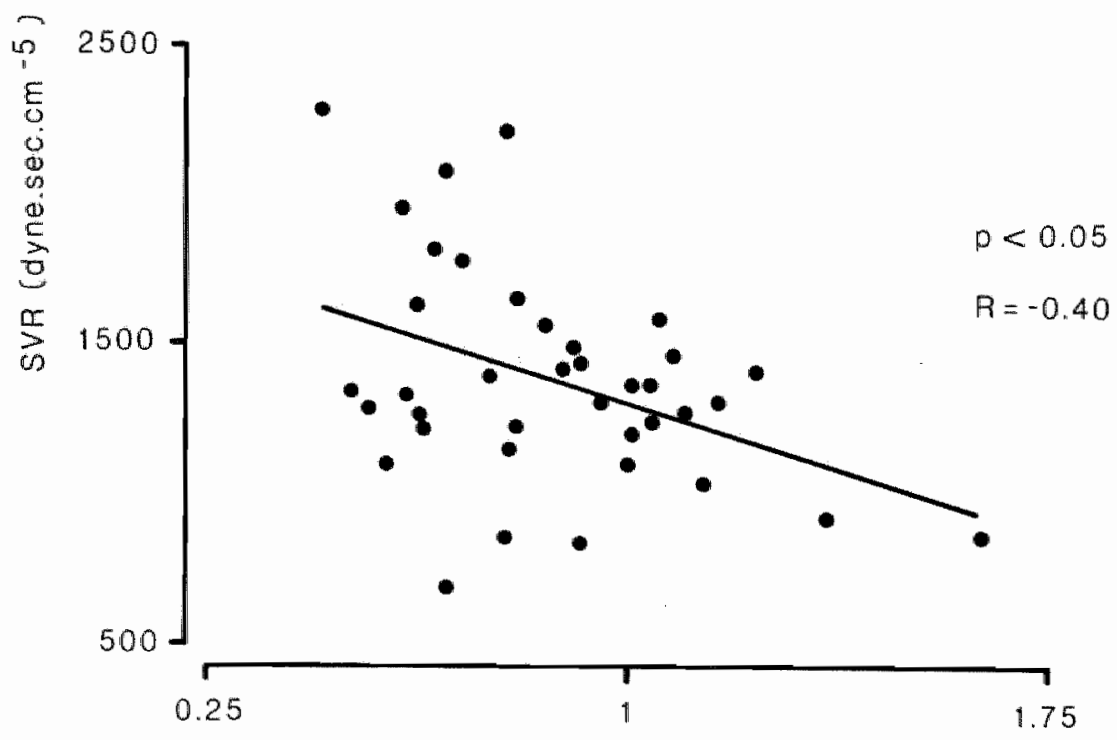

FEV 1 ( 1$)$ 
Figuur 49: Relatie tussen $\mathrm{FEV}_{1}$ en systemische zuurstofopname.

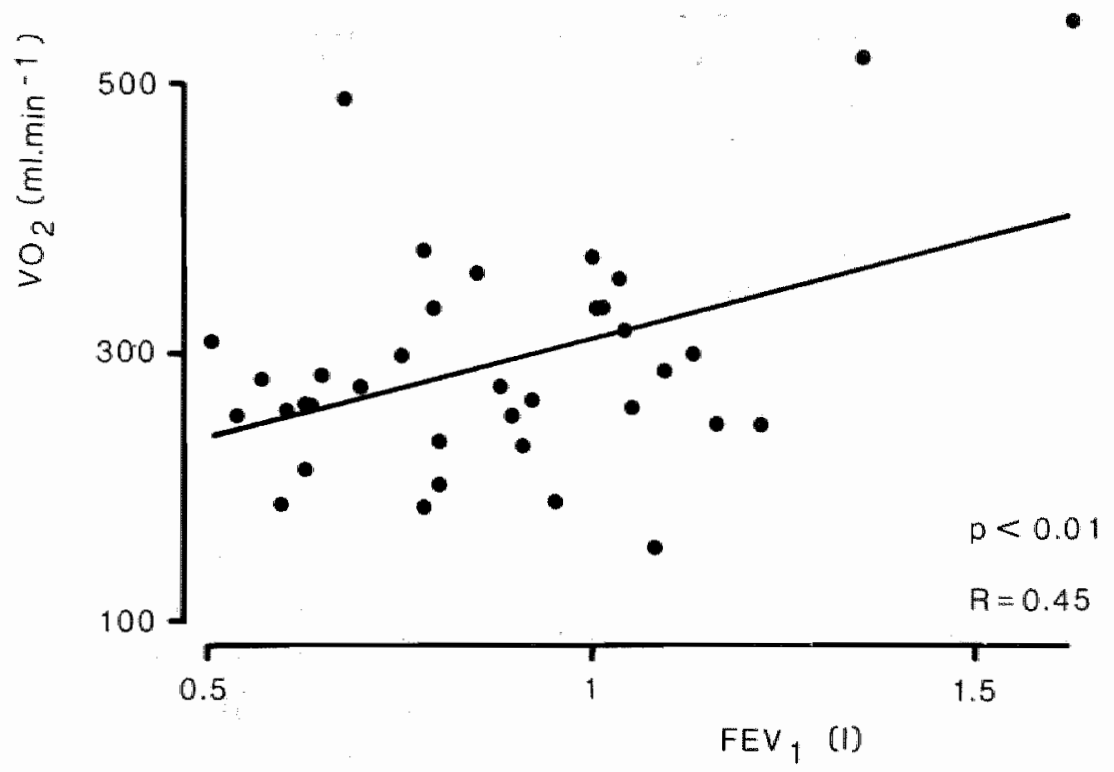

Figuur 4.10: Relatie tussen FEV, en RPF.

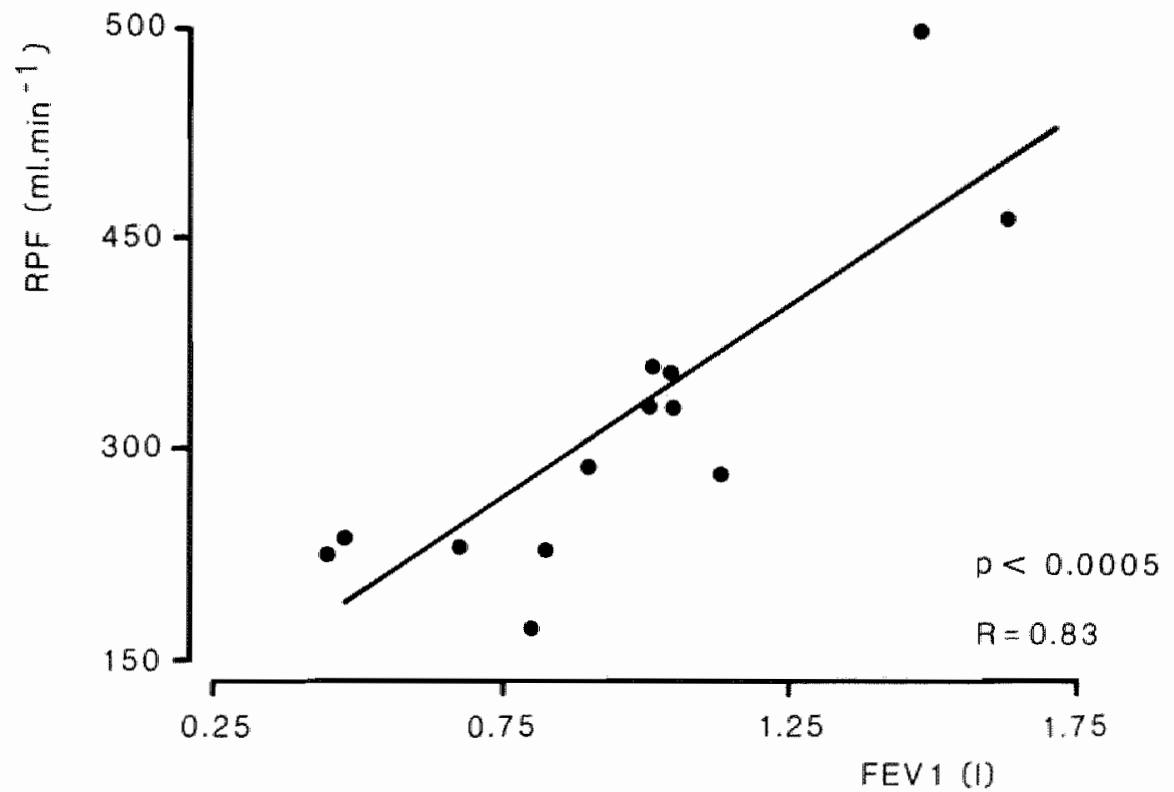


Tabel 4,6: Correlatie urssen algenene gegevens en nierdoorbloedingen (lineäre regressie).

\begin{tabular}{lcc}
\hline variabelen & p-waarde & r-waarde \\
\hline leeftijd - RPF & $<0.05$ & -0.60 \\
leeftijd - RBP & $<0.05$ & -0.66 \\
leeftijd - RVR & $<0.005$ & 0.72 \\
FEV $_{1}-$ RPF & $<0.001$ & 0.89 \\
FEV $_{1}-$ RBF & $<0.001$ & 0.88 \\
FEV $_{1}-$ RVR & $<0.005$ & -0.81 \\
\hline
\end{tabular}

\subsubsection{Gaswaarden en haemodynamiek}

In de verbanden tussen de gaswaarden en de haemodynamiek (systemisch, pulmonaal en renaal) valt de nadruk op de rol van de $\mathrm{PaCO}_{2}$. Enerzijds wordt een omgekeerde relatie gevonden tussen $\mathrm{PaCO}_{2}$ en vaatweerstand (figuur 4.11), anderzijds blijkt de $\mathrm{PaCO}_{2}$ gerelateerd aan toename in de mPAP en RVSWI (figuur 4.12 en 4.13) en aan beperking van de RPF (figur 4.14). Kortom, er is sprake van systemisch vasodilatatie en renale vasoconstrictie, terwijl het longvaatbed druktoename toont in aanwezigheid van hypercapnie.

Figuur 4.11: Relatie tussen $\mathrm{PaCO}_{2}$ en systemische vaatweerstand.

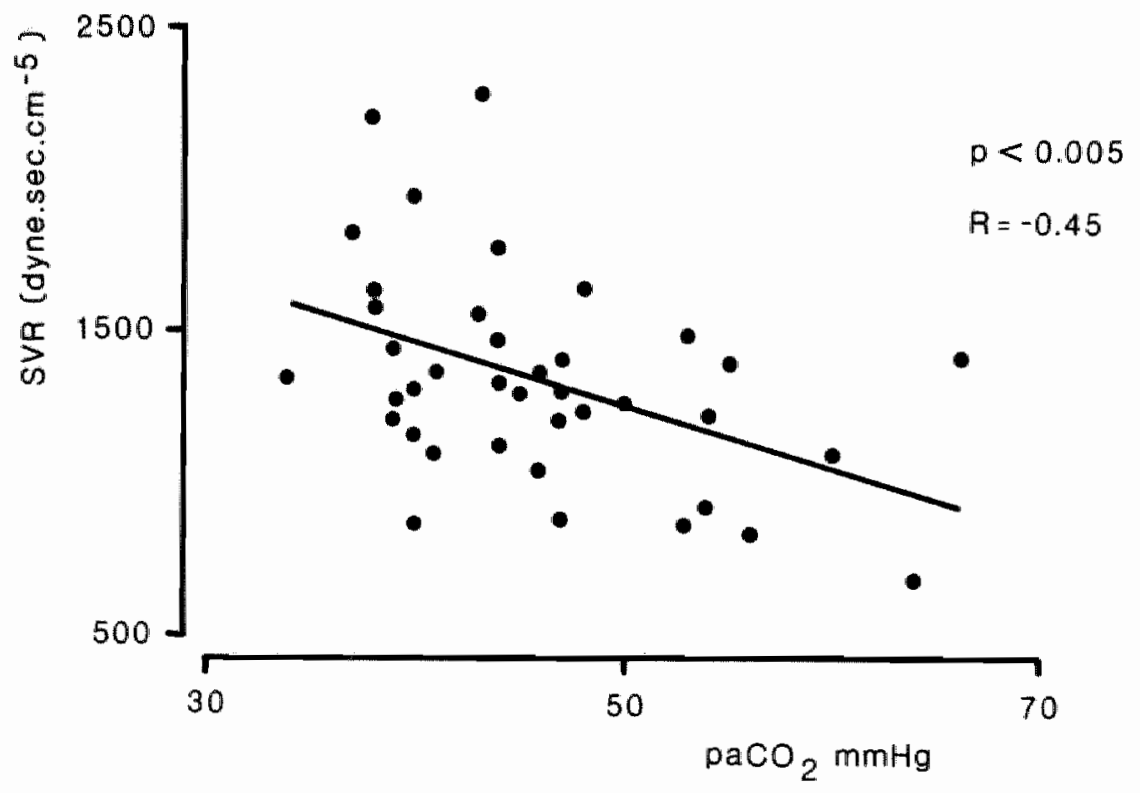


Figuur 4.12: Relatie tussen $\mathrm{PaCO}_{2}$ en mPAP.

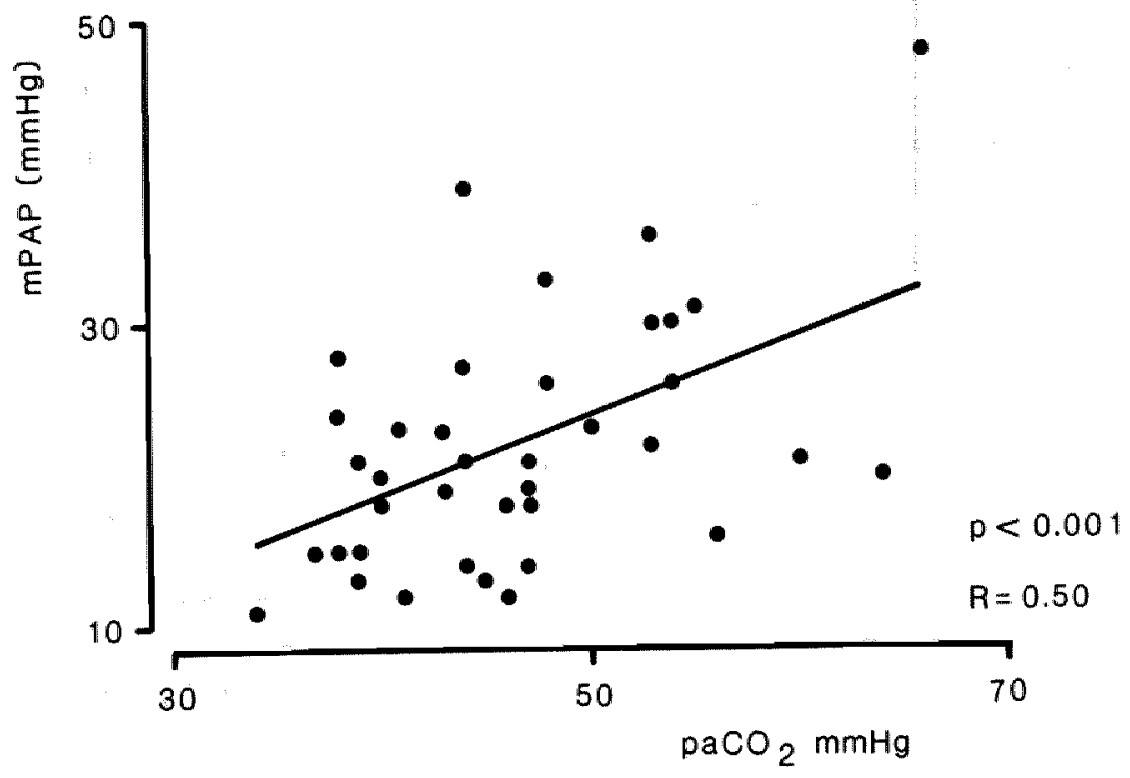

Figuur 4.13: Relatie tussen $\mathrm{PaCO}_{2}$ en arbeidsindex van de rechter ventrikel (RVSWI).

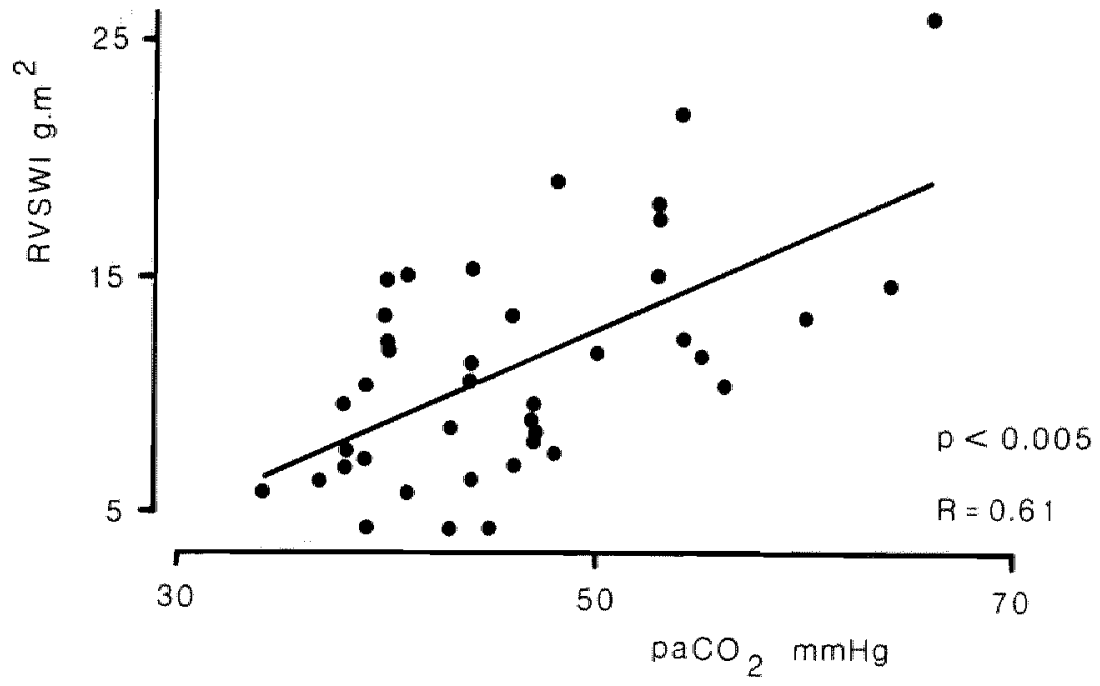


Figutir 4.14: Relatie tussen $\mathrm{PaCO}_{2}$ en $\mathrm{RPF}$.

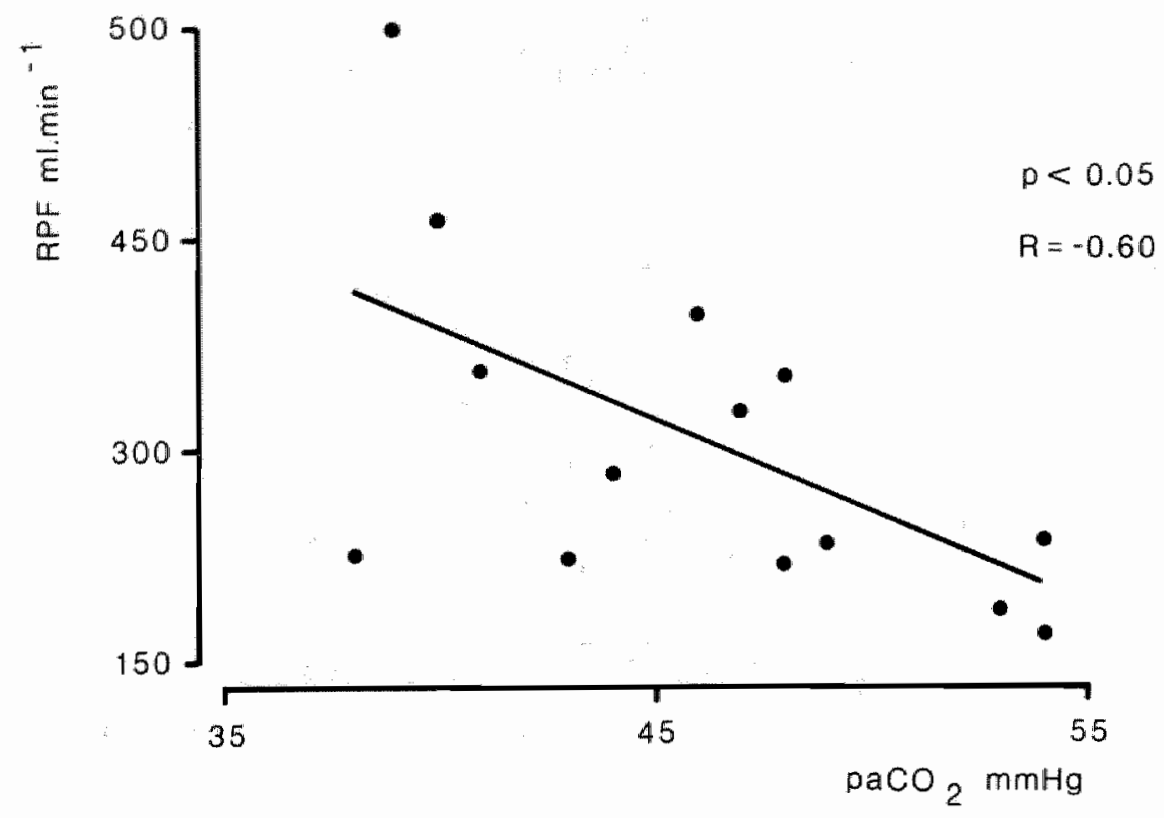

De overige parameters van de gaswaarden en het zuurstoftransport bleken eveneens in verband te staan met de nierdoorbloeding (tabel 4.7). Onder de gekozen studieomstandigheden van normoxie, bleken de inspiratoire zuurstoffractie en de $\mathrm{SvO}_{2}$ niet significant gecorreleerd aan de RVR en RBF.

Voor het zuurstoftransport en het verbruik ( $\mathrm{SOT}$ en $\mathrm{VO}_{2}$ ) werden sterkere relaties met de renale variabelen vastgesteld, doch het is de vraag in hoeverre deze correlaties werkelijk van betekenis zijn, gezien het eerder vastgestelde verband tussen $C O$ en $R B F(p<0.05, r=$ $0.62)$.

Daarentegen lijkt de relatie tussen de onafhankelijk gemeten variabelen $\mathrm{PaCO}_{2}$ en $\mathrm{RPF}$ reëel (tabel 4.7 en figuur 4.14). Een nog sterkere significantie werd gezien als het arteriële $\mathrm{HCO}_{3}$. werd gecorreleerd aan de RPF (figur 4.15). 
Tabel 4.7: Verband tussen nierdoorbloeding en gaswasrden (lineaire regressie).

\begin{tabular}{lcr}
\hline wariabelen & $\mathrm{p}$ & $\mathrm{r}$ \\
\hline $\mathrm{FiO}_{2}-\mathrm{RVR}$ & $0.05<\mathrm{p}<0.10$ & -0.48 \\
$\mathrm{FiO}_{2}-\mathrm{RBF}$ & $0.05<\mathrm{p}<0.10$ & 0.49 \\
$\mathrm{SvO}_{2}-\mathrm{RVR}$ & $\mathrm{NS}$ & -0.55 \\
$\mathrm{VO}_{2}-\mathrm{RVR}$ & $<0.05$ & -0.62 \\
$\mathrm{VO}_{2}-\mathrm{RPF}$ & $<0.05$ & 0.64 \\
$\mathrm{SOT}-\mathrm{RVR}$ & $<0.01$ & -0.72 \\
$\mathrm{SOT}-\mathrm{RPF}$ & $0.05<\mathrm{p}<0.10$ & \\
$\mathrm{PaCO}_{2}-\mathrm{RVR}$ & $\mathrm{NS}$ & 0.35 \\
$\mathrm{PaCO}_{2}-\mathrm{RPF}$ & $<0.05$ & -0.60 \\
$\mathrm{HCO}_{3}-\mathrm{RPF}$ & $<0.0005$ & -0.81 \\
\hline
\end{tabular}

Figuur 4.15: Relatie tussen arterieel $\mathrm{HCO}_{3}{ }^{-}$-gehalte en RPF.

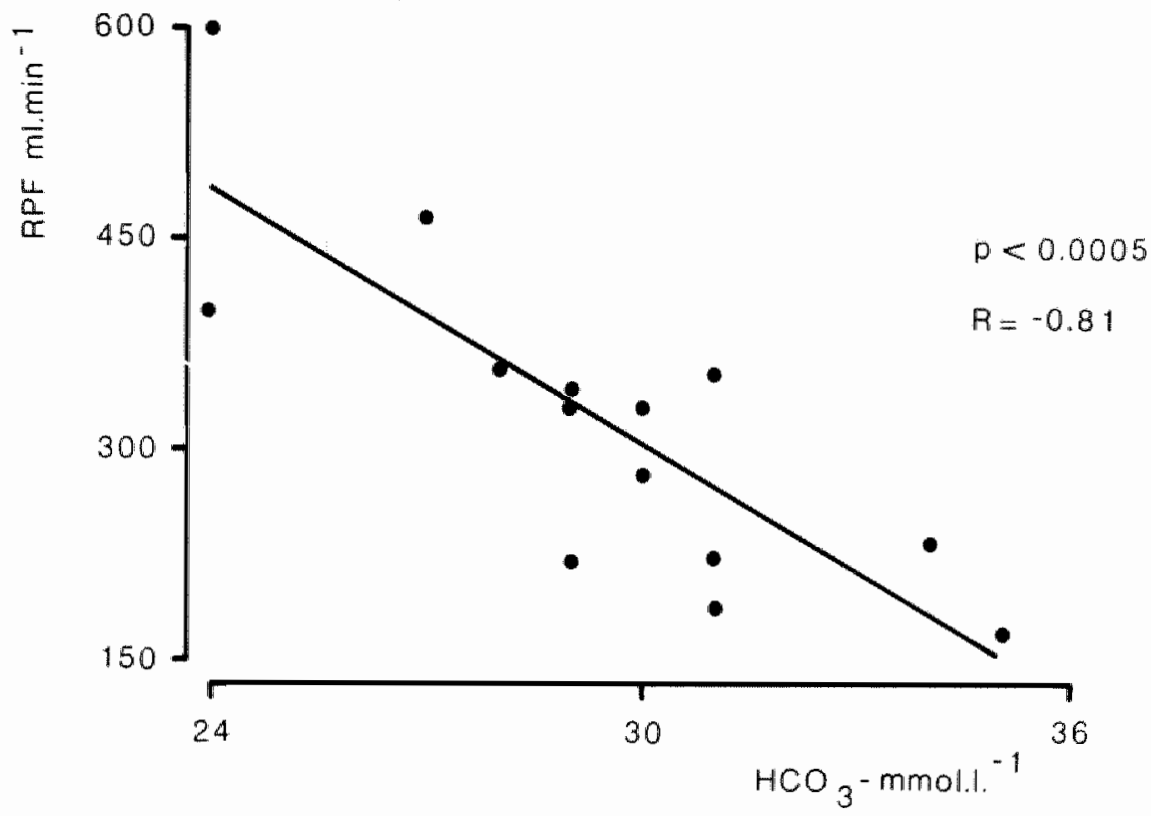




\subsection{Neuro-endocriene activiteit}

\subsubsection{Neuro-endocriene gegevens en gaswaarden}

Bij de analyse van de bepalingen van de catecholamines (respectievelijk noradrenaline, adrenaline en dopamine) viel de nadruk op het verband tussen de gemengd-veneuze adrenaline- en noradrenaline-gehaltes en de arteriële gaswaarden. De relaties zijn weergegeven in tabel 4.8 en figuren 4.16 en 4.17 . Het belang van het dopamine-gehalte lijkt minder groot.

Het meest opvallend is dat de arteriële zuurstofsaturatie (de zuurstofspanning in mindere mate) correleert met het gemengd-veneuze adrenaline. Daarentegen blijkt de $\mathrm{PaCO}_{2}$ gekoppeld aan zowel het gernengd-veneuze als aan het arteriële adrenaline-gehalte; daarnaast ook, zij het minder duidelijk, aan het noradrenaline-gehalte. In vroegere studies, waar hypercapnie pulmonale vasoconstrictie veroorzaakte, was de daarbij geïnduceerde $\mathrm{pH}$ verandering een punt van discussie [Malik et al 1973]. Er kon hier geen verband vastgesteld worden tussen de catecholamines en de $\mathrm{pH}$.

Tabel 4.8: Verband tussen gaswaarden en de catecholamines.

\begin{tabular}{|c|c|c|c|c|}
\hline & arter & & gemengd & eus \\
\hline & $\mathbf{p}$ & $\mathbf{r}$ & $\mathbf{p}$ & $\mathbf{r}$ \\
\hline adrenalin & & & & \\
\hline$-\mathrm{PaO}_{2}$ & NS & -0.23 & $<0.05$ & -0.60 \\
\hline$-\mathrm{SaO}_{2}$ & $0.05<\mathrm{p}<0.10$ & -0.43 & $<0.01$ & -0.68 \\
\hline$-\mathrm{PvO}_{2}$ & NS & 0.14 & NS & 0.32 \\
\hline$-\mathrm{SvO}_{2}$ & NS & 0.28 & NS & 0.36 \\
\hline$-\mathrm{PaCO}_{2}$ & $<0.01$ & 0.62 & $<0.05$ & 0.57 \\
\hline$-\mathrm{pH}$ & NS & 0.26 & NS & 0.24 \\
\hline noradren & & & & \\
\hline - $\mathrm{PaO}_{2}$ & NS & 0.14 & NS & 0.14 \\
\hline$-\mathrm{SaO}_{2}$ & NS & 0.11 & NS & 0.31 \\
\hline - $\mathrm{PrO}_{2}$ & $M S$ & 0.24 & NS & 0.24 \\
\hline$-\mathrm{SvO}_{2}$ & $\mathrm{NS}$ & 0.31 & NS & 0.32 \\
\hline$-\mathrm{PaCO}_{2}$ & $0.05<p<0.10$ & 0.42 & $0.05<p<0.10$ & 0.49 \\
\hline$-p H$ & NS & 0.31 & NS & 0.32 \\
\hline
\end{tabular}


Figuur 4.16: Relatie tussen gemengd-yeneus adrenalinegehalte en $\mathrm{SaO}_{2}$,

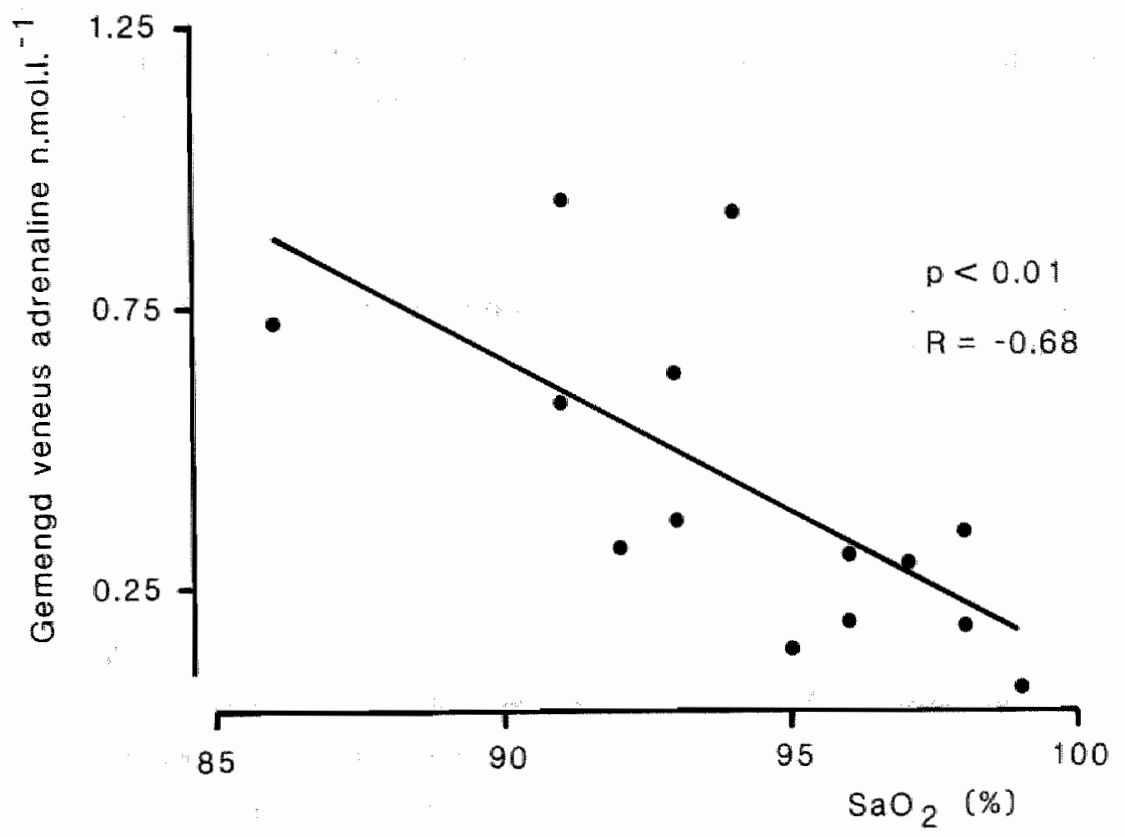

Figuur 4.17: Relatie tussen gemengd-veneus adrenalinegehalie en $\mathrm{PaCO}_{2}$.

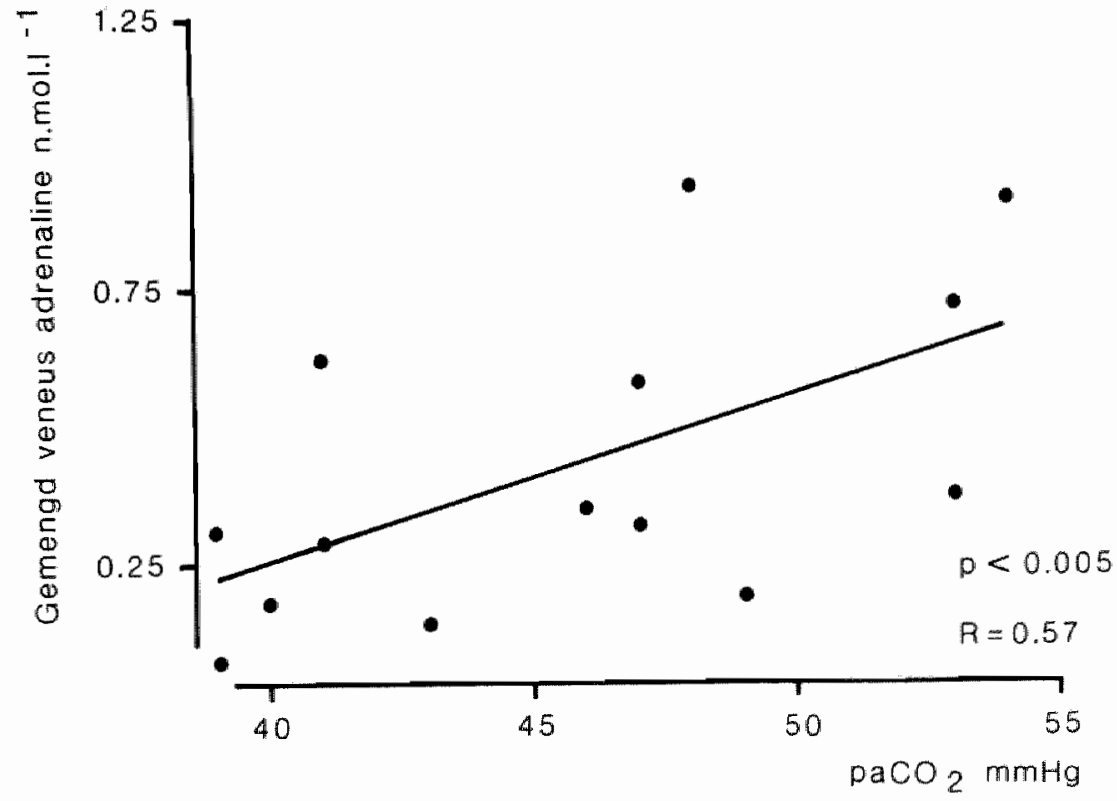




\subsubsection{Neuro-endocriene activiteit en longfunctie}

Uitgebreide analyse van longfunctie-variabelen (FEV en $\mathrm{FEV}_{1} / \mathrm{FVC}$ ), evenals van het $\mathrm{Hb}$ en $\mathrm{H}_{t}$, leverde geen duidelijke relatie op met betrekking tot de activiteit van het sympathische zenuwstelsel en het RAAS.

\subsection{Subgroepanalyse en voorspelling van de gemiddelde arteria pulmonalis- druk (mPAP)}

Het laatste onderdeel van het overzicht van de verbanden tussen de circulatoire en de respiratoire variabelen keert terug naar de $\mathrm{PaCO}_{2}$ en de $\mathrm{mPAP}$ om de invloeden van pulmonale hypertensie en hypercapnie apart te analyseren.

In de tabellen 4.9 en 4.10 zijn de subgroepen gerangschikt met en zonder pulmonale hypertensie. De basale gegevens laten zien dat er geen verschillen zijn met betrekking tot leeftijd en longfunctiestoornissen, hoewel de groep met pulmonale hypertensie neigt naar een wat lagere $\mathrm{FEV}_{1}$. Terwijl in beide groepen zuurstof per neusslang werd toegediend blijkt de saturatie iets verschillend, ten nadele van de pulmonale hypertensie-groep. In deze groep blijkt het $\mathrm{CO}_{2}$-gehalte wel significant hoger te zijn. Deze gegevens sluiten aan bij oudere gegevens, waarin werd vastgesteld dat pulmonale hypertensie en het cor pulmonale meer voorkomen bij hypercapnische patiënten en afhankelijk zijn van de FEV 1 [Renzetti et al 1966].

Tabell 4.9: Uitgangswaanden bij patienten met en zonder pulmonale hypentensic.

\begin{tabular}{|c|c|c|c|c|}
\hline variabele & eenheid & $\mathrm{mPAP} \leq 20 \mathrm{mmiHg}$ & $\mathrm{mPAP}>20 \mathrm{mmHg}$ & $\mathrm{p}$ \\
\hline n & & 20 & 20 & \\
\hline leeftijd & (jaren) & $66 \pm 10$ & $68 \pm 7$ & $\mathrm{NS}$ \\
\hline $\mathrm{Hb}$ & $\left(\right.$ mmolit $\left.1^{-1}\right)$ & $10.2 \pm 1.2$ & $10.2 \pm 0.9$ & NS \\
\hline $\mathrm{Ht}$ & $\left(11^{18}\right)$ & $0.49 \pm 0.05$ & $0.51 \pm 0.04$ & NS \\
\hline $\mathrm{FEV}_{1}$ & (D) & $0.90 \pm 0.29$ & $0.84 \pm 0.20$ & NS \\
\hline$F E V_{1}-F V C$ & $(\%)$ & $0.37 \pm 0.07$ & $0.35 \pm 0.11$ & NS \\
\hline $\mathrm{PaO}_{2}$ & $(\mathrm{mmHg})$ & $74 \pm 18$ & $72 \pm 20$ & $\mathrm{NS}$ \\
\hline $\mathrm{PrO}_{2}$ & $(\mathrm{mmHg})$ & 37 幽 4 & $39 \pm 4$ & NS \\
\hline $\mathrm{PaCO}_{\mathrm{a}}$ & $(\mathrm{nmHg})$ & $44 \pm 7$ & $49 \pm 7$ & $<0.05$ \\
\hline $\mathrm{FiO}_{2}$ & $(\%)$ & $24 \pm 4$ & $24 \pm 2$ & NS \\
\hline $\mathrm{SaO}_{2}$ & $(\%)$ & $94 \pm 2$ & $92 \pm 4$ & $0.05<\mathrm{p}<0.10$ \\
\hline
\end{tabular}


Tabel 4.10: Haemodynamiek bij patienten met en zonder pulmonale hypertensie.

\begin{tabular}{|c|c|c|c|c|}
\hline wariabele & eenheid & $\mathrm{mPA} \mathbf{I}^{\mathrm{P}} \leq 20 \mathrm{mmHg}$ & $\mathrm{mPAP}>20$ mmHg & p \\
\hline $\mathbf{n}$ & & 20 & 20 & \\
\hline MAP & $(\mathrm{mmHg})$ & $87 \pm 13$ & $97 \pm 11$ & $<0.05$ \\
\hline RAP & $(\mathrm{mmHg})$ & $2 \pm 3$ & $3 \pm 3$ & $\mathrm{NS}$ \\
\hline PCWP & $(\mathrm{mmHg})$ & $6 \pm 3$ & $7 \pm 3$ & NS \\
\hline perfusiegradient & $(\mathrm{mmHg})$ & $14 \pm 4$ & $21 \pm 7$ & $<0.001$ \\
\hline $\mathrm{HF}$ & (slagen.min ${ }^{-1}$ ) & $83 \pm 14$ & $93 \pm 12$ & $<0.05$ \\
\hline $\mathrm{CO}$ & $\left(1 \min ^{-1}\right)$ & $5.61 \pm 1.26$ & $5.83 \pm 1.57$ & NS \\
\hline sV & $\left(\mathrm{ml} . \mathrm{slag}^{\mathrm{N}}\right)$ & $70 \pm 20$ & $63 \pm 18$ & NS \\
\hline SVR & (dyne.sec.cm ${ }^{-5}$ ) & $1306 \pm 385$ & $1359 \pm 326$ & NS \\
\hline PVR & $\left(\right.$ dyne.sect.cm $\left.{ }^{-5}\right)$ & $162 \pm 47$ & $303 \pm 123$ & $<0.05^{\circ}$ \\
\hline LVSWI & $\left(g \cdot \mathrm{m}^{-2}\right)$ & $45 \pm 12$ & $46 \pm 13$ & $\mathrm{NS}$ \\
\hline RVSWI & $\left(\mathrm{g} \cdot \mathrm{m}^{-2}\right)$ & $9 \pm 3$ & $1.4 \pm 5$ & $<0.005^{\circ}$ \\
\hline shunt & $(\%)$ & $21 \pm 8$ & $25 \pm 11$ & NS \\
\hline SOT & $\left(\mathrm{ml} \mathrm{min}^{-1}\right)$ & $1170 \pm 334$ & $1189 \pm 340$ & NS \\
\hline $\mathrm{VO}_{2}$ & $\left(\mathrm{ml} . \mathrm{min}^{-1}\right)$ & $296 \pm 89$ & $291 \pm 83$ & NS \\
\hline
\end{tabular}

De haemodynamische gegevens laten zien dat beide groepen vergelijkbaar zijn qua vullingstoestand gemeten aan de RAP en PCWP, doch de MAP en HF zijn significant hoger in de groep met pulmonale hypertensie, zonder dat dit leidt tot verschillen in de arbeidsindex van het linker ventrikel of in het gastransport. De verschillen in perfusiegradiënt, PVR en RVSWI volgen rekenkundig uit het verschil in mPAP.

De gegevens tonen aan dat de gaswisseling in de pulmonale hypertensieve groep meer werstoord is. Behalve het verschil in $\mathrm{PaCO}_{2}$ is ook het verschil in hartfrequentie ten opzichte van de overige patiënten opvallend. In de literatuur is eerder het verband tussen hypoxie, verhoogde mPAP en een versnelde hartslag gelegd [Hedemark ef al 1982]. Het meten van de hartfrequentie tijdens de slaap is ook als diagnosticum naar voren gebracht [Gimeno Orlega el al 1986].

De basale gegevens, na rangschikking volgens de aan- of afwezigheid van hypercapnie, zijn vermeld in tabel 4.11. Deze gegevens laten geen verschillen zien tussen de twee subgroepen; de haemodynamiek is evenwel anders bij hypercapnici in vergelijking tot normocapnici (tabel 4.12). Opvallende verschillen in hartminuutvolume, SVI en zuurstoftransport, bij gelijkblijven van de vullingsdrukken en ondanks een iets hogere mPAP bij hypercapnici. 
Tabel 4.11: Basale gegevens, rangschikking naar aanwezigheid van hypercapnie.

\begin{tabular}{llccc}
\hline variabele & eenheid & $\mathrm{PaCO}_{2} \leq 45 \mathrm{mmiHg}$ & $\mathrm{FaCO}_{2}>45 \mathrm{mmHg}$ & $\mathrm{p}$ \\
\hline $\mathrm{n}$ & & 19 & 21 & \\
leeftijd & (Garen) & $68 \pm 9$ & $65 \pm 8$ & $\mathrm{NS}$ \\
$\mathrm{Hb}$ & (mmol. $\left.{ }^{-1}\right)$ & $10.0 \pm 0.8$ & $10.4 \pm 1.11$ & $\mathrm{NS}$ \\
$\mathrm{Ht}$ & $\left(1.1^{-1}\right)$ & $0.49 \pm 0.04$ & $0.51 \pm 0.05$ & $\mathrm{NS}$ \\
$\mathrm{FEV}$ & $(1)$ & $0.85 \pm 0.27$ & $0.91 \pm 0.22$ & $\mathrm{NS}$ \\
$\mathrm{FEV}_{1} / \mathrm{FVC}$ & $(\%)$ & $0.36 \pm 0.08$ & $0.35 \pm 0.11$ & $\mathrm{NS}$ \\
$\mathrm{PaO}_{2}$ & $(\mathrm{mmHg})$ & $74 \pm 20$ & $72 \pm 18$ & $\mathrm{NS}$ \\
$\mathrm{PWO}_{2}$ & $(\mathrm{mmHg})$ & $36 \pm 4$ & $40 \pm 3$ & $\mathrm{NS}$ \\
$\mathrm{FiO}_{2}$ & $(\%)$ & $23 \pm 2$ & $25 \pm 3$ & $\mathrm{NS}$ \\
$\mathrm{SaO}_{2}$ & $(\%)$ & $94 \pm 3$ & $92 \pm 3$ & $\mathrm{NS}$ \\
& & & &
\end{tabular}

Tabel 4.12: Haemodynamiek, in relatie tot aamwezigheid wan hypercapnie.

\begin{tabular}{|c|c|c|c|c|}
\hline variabele & eenheid & $\mathrm{PaCO}_{2} \leq 45 \mathrm{mmHg}$ & $\mathrm{PaCO}_{2}>45 \mathrm{mmHg}$ & p \\
\hline n & & 21 & 19 & \\
\hline MAP & $(\mathrm{mmHg})$ & $92 \pm 13$ & $92 \pm 14$ & NS \\
\hline MPAP & $(\mathrm{mmHg})$ & $20 \pm 7$ & $24 \pm 9$ & $0.05<p<0.10$ \\
\hline RAP & $(\mathrm{mmHg})$ & $2 \pm 2$ & $3 \pm 3$ & NS \\
\hline PCWP & $(\mathrm{mmH} H)$ & $6 \pm 3$ & $7 \pm 3$ & NS \\
\hline perfusiegradient & $(\mathrm{mmHg})$ & $13 \pm 6$ & $18 \pm 8$ & NS \\
\hline $\mathrm{HF}^{2}$ & (slagen.min ${ }^{4}$ ) & $87 \pm 14$ & $90 \pm 15$ & $\mathbb{N S}$ \\
\hline $\mathrm{CO}$ & $\left(1 . \mathrm{min}^{-1}\right)$ & $5.14 \pm 1.10$ & $6.34 \pm 1.47$ & $<0.005$ \\
\hline SV & $\left(\mathrm{ml} . \mathrm{slag}^{-1}\right)$ & $61 \pm 19$ & $72 \pm 18$ & 0.05 \\
\hline SVR & (dyne.sec. $\mathrm{cm}^{-5}$ ) & $1482 \pm 360$ & $1168 \pm 265$ & $<0,01$ \\
\hline PVR & (dyne.sec. $\left.\mathrm{cm}^{-5}\right)$ & $230 \pm 119$ & $235 \pm 119$ & NS \\
\hline LVSWI & $\left(\mathrm{g} \cdot \mathrm{m}^{-2}\right)$ & $42 \pm 12$ & $49 \pm 11$ & $0.05<p<0.10$ \\
\hline RVSWI & $\left(g \cdot m^{-2}\right)$ & $9 \pm 4$ & $13 \pm 5$ & $<0.005$ \\
\hline shunt & $(\%)$ & $22 \pm 9$ & $26 \pm 10$ & NS \\
\hline SOT & $\left(\right.$ milmin $\left.\min ^{-1}\right)$ & $1053 \pm 277$ & $\$ 3.19 \pm 340$ & $<0.05$ \\
\hline $\mathrm{VO}_{2}$ & $\left(\right.$ mil.min $\left.^{-1}\right)$ & $275 \pm 87$ & $314 \pm 81$ & NS \\
\hline
\end{tabular}


Indien de verschillen samengevat worden met betrekking tot de subgroepen, valt te concluderen dat pulmonale hypertensie gepaard gaat met een hogere gemiddelde bloeddruk zonder verschillen in minuutvolume of vaatweerstand, terwijl de hartfrequentie en de arbeid voor de rechter ventrikel hoger zijn geworden. Daarentegen gaat hypercapnie gepaard met een systemische vasodilatatie, waardoor het hartminuutvolume is gestegen. Dit leidt tot een toename in systemisch zuurstoftransport, welke in rust niet gepaard gaat met een toegenomen verbruik van zuurstof op weefselniveau.

Uit de eerdere gegevens met betrekking tot de mPAP viel op dat deze parameter werd beînvloed door de $\mathrm{PaCO}_{2}$ (figuur 4.12) en meerdere haemodynamische variabelen (tabel 4.5 en figurur 4.6). Gezien deze bevindingen werd multivariate analyse verricht, watarbij stapsgewijs de significante variabelen werden verwerkt. Na invoering van de MAP en $\mathrm{PaCO}_{2}$ bleken deze parameters als enige significant te zijn gerelateerd aan de mPAP.

Vervolgens werd onderzocht of deze eenvoudig te bepalen parameters de aanwezigheid van pulmonale hypertensie zouden kunnen voorspellen. Daartoe werd gebruik gemaakt van het diagram uit tabel 4.13. Bij het bestuderen van de omslagpunten gaven MAP $>85 \mathrm{mmHg}$ en $\mathrm{PaCO}_{2}>45 \mathrm{mmHg}$ de beste resultaten. De voorspellende waarde voor de gekozen omslagpunten lag rond de 70\% (tabel 4.14). Een combinatie van beide variabelen leverde een hoge voorspellende waarde op. Wij moeten daarbij wel bedenken dat patiënten met een diastolische bloeddruk hoger dan $100 \mathrm{mmHg}$ waren uitgesloten van de studie. Inclusie van deze patiènten zou mogelijk de sensitiviteit en specificiteit gunstig kunnen beïnvloeden.

Tabel 4.13: Diagram ter voorspelling van de aanwezigheid van pulmonale hypertensie.

\begin{tabular}{|c|c|c|}
\hline & $\begin{array}{c}\text { patiënten met } \\
\text { pulmonale hypertensie }\end{array}$ & $\begin{array}{c}\text { patiënten zonder } \\
\text { puImonale hypertensîe }\end{array}$ \\
\hline positieve variabele & A & $\mathrm{C}$ \\
\hline negatieve variabele & B & $\mathrm{D}$ \\
\hline \multicolumn{3}{|c|}{$A, B, C$ en $D$ geven de antallen patiernten weer } \\
\hline sensitiviteir & $=A /(A+B)$ & \\
\hline specificiteit & $=\mathrm{D} /(\mathrm{D}+\mathrm{C})$ & \\
\hline validiteit & $=(A+B) /(A+B+C+D)$ & \\
\hline woorspellende waarde & $=A \cdot(A+C)$ & \\
\hline
\end{tabular}


Tabel 4.14* Sensitiviteit, specifichteit, validiteit en voorspellemele waarde van de MAP en $\mathrm{PaCO}_{2}$ met betrekking tot de aanwezigheid wan pulmonale hypentensice in rust.

\begin{tabular}{lcccc}
\hline & semsitiviteit & specificiteilt & validiteit & $\begin{array}{c}\text { voorspellende } \\
\text { waarde }\end{array}$ \\
\hline $\mathrm{MAP}>85 \mathrm{mmHg}$ & 93 & 55 & 74 & 70 \\
$\mathrm{PaCO}>45 \mathrm{mmHg}$ & 65 & 67 & 66 & 71 \\
$\mathrm{MAP}>85 \mathrm{mmHg}$ en $\mathrm{PaCO}_{2}>45 \mathrm{mmHg}$ & 93 & 75 & 86 & 87 \\
\hline
\end{tabular}

\subsection{Bespreking}

Indien getracht wordl de beschreven resultaten samen te vatten in vergelijking tot literatuurgegevens, kan gesteld worden dat de bevindingen met betrekking tot oxygenatie en gemengd-veneuze catecholamines nieuw zijn, evenals het directe verband tussen de longfunctie en nierdoorbloeding. De verbanden tussen gaswaarden en nierdoorbloedingen, ditmaal onder omstandigheden wan normoxie, bevestigen de invloed van het $\mathrm{CO}_{2}$-gehalte op de renale haemodynamiek.

Bij de specifieke bespreking van de resultaten worden de circulatoire en ademhalingsgegevens op de voet gevolgd. Ten aanzien van de algemene gegevens valt op dat secundaire polycythaemie bij $40 \%$ van de patiënten voor kwam. Een stijging van de hematocriet is een bekend gevolg van chronische hypoxie. De secundaire polycythaemie verhoogt weliswaar de capaciteit voor zuurstoftransport, doch is niet zonder gevaren. In de MRCWP-studie naar de overleving tijdens OZT, was de Ht, zij het zwak, gerelateerd aan het mortaliteitsrisico [MRCWP 1981]. Een fysiologisch probleem is de toename in viscositeit, welke via een stroeve circulatie het zuurstoftransport ongunstig beïnloedt [Wedzicha et al 1983].

Daarnaast kan een hoog $\mathrm{Hb}$ wijzen op een laag intravasculair volume, zeker bij gebruik van diuretica. Een laag intravasculair volume leidt tot een daling van de veneuze terugstroom en van de RAP. De veneuze terugstroom is niet zonder praktisch belang. Het verklaart de problemen bij flebotomie en diuretica-gebruik, als door volumeverlies niet alleen het $\mathrm{Hb}_{\text {, }}$ maar ook ondanks influx van interstitiële vloeistof het circulerend volume zakt, met kans op hypotensie. Dit heeft geleid tot het advies flebotomie te combineren met plasmatoediening, of het effect van OZT af te wachten [Weisse et al 1975]. Overigens leidt correctie wan de polycythaemie en viscositeit wel tot verbetering van de inspanningscapaciteit, met name als de uitgangswarde van de Ht de $55 \%$ overschrijdt [Chetty et al 1983]. 
De anwezigheid van hoge hematocriet-waarden pleit wel voor chronische stimulatie van het erytropoietinesysteem. Overigens suggereren literatuurgegevens dat de stijging van de hematocriet tijdens erytropoietinetherapie veelal een lastig te behandelen hypertensie veroorzaakt [Adamson 1989, Hambley en Mufty 1990]. Op theoretische gronden zou dus het erythropoietine kunnen bijdragen aan het woorkomen van hypertensie bij het hypoxisch obstructief longlijden. Bij onze patiënten was er door voorselectie geen sprake van hypertensie.

De erythropoietine-spiegels bij onze patiënten waren echter niet verhoogd. Mogelijk dat de studieopzet en de korte halfwaardetijd van het erythropoietine de normale spiegels verklaren, zoals eerder vastgesteld bij kortdurende hypoxie [Stradling 1989].

Met betrekking tot de neuro-humorale factoren en de nierdoorstroming bij onze patiënten, vielen de hoge renine-spiegels en de laag-normale RPF op. Ondanks verhogingen van het renine waren de A II en aldosteronwaarden normaal; hetzelfde gold voor de catecholaminen. Gezien deze bevindingen werd in de groep van 14 patiënten nagegaan of de renine-activatie niet samenhing met ondervulling of diuretica-gebruik. Van beide bleek geen sprake te zijn. De systemische haemodynamiek toonde een normaal beeld (PCWP $7 \pm 4 \mathrm{mmHg}$, SVR 1322 \pm 459 dyne.sec. $\mathrm{cm}^{-5}$ en hartminuutvolume-index $\left.3.45 \pm 0.961 . \mathrm{min}^{-1} \cdot \mathrm{m}^{-2}\right)$. Ook het normale noradrenalinegehalte pleit tegen ondervulling waar een verhoogd noradrenaline een indicator is voor arteriële ondervulling [Schrier 1987]. De gegevens uit onze studie geven geen antwoord op de vraag of de activiteit van het ACE geremd wordt tijdens hypoxie.

Verhoogde renine-spiegels hebben mogelijk een prognostische betekenis. Het is interessant deze spiegels te leggen naast gegevens uit het hypertensieonderzoek. Zo is gesteld dat een initieel verhoogd plasma-renine bij patiënten met hypertensie een belangrijke risicofactor zou zijn voor cardiovasculaire complicaties, ongeacht de te volgen behandeling [Laragh 1991].

De normale uitslagen met betrekking to de hartminuutvolume-index in rust, bevestigen literatuurgegevens dat het hartminuutvolume bij stabiele patiënten met cor pulmonale normaal is [MacNee et al 1988]. Uit studies bij patiënten met cor pulmonale, bij wie hartcatheterisatie verricht werd wegens verdenking op coronair lijden, is gebleken dat in deze patiënten slechts bij uitzondering sprake is van coronair lijden of verminderde linkerventrikelfunctie [Steel et al 1975]. De constatering dat bij de helft van de patiënten inderdaad een verhoogde mPAP aanwezig was, komt overeen met de ervaring van andere onderzoekers. In een onderzoek naar milde pulmonale hypertensie, vanuit dezelfde 
diagnostiek alls hier gepleegd, werd in een derde deel van het aantal patiënten een verhoogde mPAP in rust gevonden [Keller et al 1986”.

De onderlinge verbanden tussen de circulatoire parameters komen vooral naar woren in de relatie MAP - MPAP.

In tegenstelling tot de situatie bij patiènten met essentiêle hypertensie [Fagard et al 1988], bleek bij onze patienten het verband tussen MAP en mPAP niet afhankelijk van de wiggedruk. Bij patienten met het obstructieve-apnoe-syndroom, dikwijls gekenmerkt door systemische en pulmonale hypertensie, kan chirurgische correctie van de uvula leiden tot normalisatie van de arteriele bloeddruk [Lund-Johansen en White 1990].

Het is nog onduidelijk in hoeverre de vaatwandprocessen verlopen onder invloed van de in de ademhaling optredende drukverschillen in de luchtwegen. Deze zogenaamde ademhalingsafhankelijke variatie in de pulmonale arteriële compliantie verdient nader onderzoek [Grant et al 1991]. Het is de vraag onduidelijk hoe het verband tussen bloeddrukniveau in de grote en kleine circulatie precies tot stand komt. Als verklaring kan gedacht worden aan de rol van systemische vasoconstrictoren of van lokale vaatwandfactoren zoals het EDRF (Endothelium Derived Relaxant Factor). Het EDRF is een stof met relaxerende eigenschappen. In de nier zou het vrijkomen van EDRF de renine-secretie remmen. Daartegenover zijn er dier-experimentele aanwijzingen dat de vaatwand onder invloed van hypoxie endotheelafhankelijke vasoconstrictie (het "endotheline") tot stand brengt [Vanhoutte 1988]. Bij het zoeken naar een gemeenschappelijke oorzaak voor de pulmonale en systemische bloeddrukregulatie zou dus aan een EDRF tekort of een chronische afgifte van een vasoconstrictor gedacht kunnen worden. In recent onderzoek bij de mens is vastgesteld dat de "endotheel-afhankelijke" relaxatie van de arteria pulmonalis bij patiënten met hypoxisch longlijden beperkt is [Dinh-Xuan et al 1991].

In de relaties tussen de circulatoire en respiratoire variabelen treedt een tweetal aspecten op de voorgrond. Enerzijds de rol van de catecholaminen en het renine, anderzijds de relatie tussen longfunctie en de nierdoorbloeding.

Het is duidelijk dat een forse beperking van de FEV, naar twee zijden ongunstig is, terwijl de ademarbeid en de zuurstofbehoefte stijgen [Lanigan et al 1990], treedt juist een verdere beperking op van zuurstofverbruik op weefselniveau (figuur 4.9). Het in onze patiënten vastgestelde verband tussen hypercapnie en extra pulmonale en extra-renale vaatverwijding (figuur 4.11) zow men zelfs kunnen beschouwen als een aanpassing om toch het zuurstoftransport op peil te houden. 
Daarentegen gaat de arbeidsindex van het rechter ventrikel omhoog en stijgt, indien er tevens sprake is van respiratoire acidose, de pulmonale vaatweerstand zeer snel.

In een vroeger onderzoek is een opvallende rol gesuggereerd voor het noradrenaline als pulmonale vasoconstrictor [Henriksen et al 1980]. In die studie bleek noradrenaline te zijn gecorreleerd aan de mPAP, de $\mathrm{PaCO}_{2}$ en de $\mathrm{SaO}_{2}$. De gegevens uit onze studie ondersteunen slechts ten dele deze rol; er werd slechts een trendmatig (niet significant) verband vastgesteld tussen de $\mathrm{PaCO}_{2}$ en het noradrenaline (arterieel en gemengd-veneus) (tabel 4.8) Daarentegen werd bij het onderzoek naar de betekenis van de catecholaminen in onze patiènten een meer dominante rol vastgesteld voor het gemengd-veneuze adrenaline. Uitgaande van een bronchodilaterende en vasodilaterende werking van het adrenaline wijst dit op een homeostatische reactie op de aanwezigheid van hypoxie en/of hypercapnie. Waarschijnlijk verloopt de hypoxische vasoconstrictie veel meer via de perifere chemoreceptoren en het noradrenaline.

Tussen de componenten van het RAAS en de variabelen van de pulmonale haemodynamiek of van de gaswaarden, werden geen significante relaties vastgesteld. De resultaten met betrekking tot het ANP zijn interessant in het licht wan deze bevindingen en van recente theorieën over de plaats van het ANP als regulator van de vaattonus. Het ANP zou functioneren als een pulmonaal vaatverwijdend systeem, reagerend op drukverhoging onder invloed van hypoxie en/of stimulatie wan het RAAS [Stewart et al 1991, Westendorp el al 1990]. Hoewel in onze patiëntengroep het ANP-gehalte licht verhoogd was, werd geen correlatie met de mPAP of vaattonus vastgesteld, zoals in eerdere studies [Adnot el al 1989].

De gegevens van de renine-bepalingen en de RPF bleken de resultaten te bevestigen van eerdere studies [Farber et al 1984, Mannix et al 1990, Reihman et al 1985]. In deze studies werden een daling van de natrium-excretie, van de RPF en wan de glomerular filtration rate (GFR) vastgesteld bij patiënten met hypercapnie en hypoxie. De beperkingen in de natrium-excretie en de RPF bleken te zijn gerelateerd aan de ernst wan de hypercapnie. In een experimentele studie bij honden bleek alleen de combinatie hypoxie met respiratoire acidose te leiden tot beperking in de nierdoorbloeding, hetgeen wervolgens te blokkeren was met behulp van een A II-antagonist [Colice 1988]. Onze gegevens onderscheiden zich in zoverre van deze studies, dat er bij onze patiënten sprake was van een normale oxygenatie en $\mathrm{pH}$. Onder deze omstandigheden bleek eveneens het renine verhoogd en de RPF omgekeerd gerelateerd aan de $\mathrm{PaCO}_{2}$ 
Door Raff en Levy is bij OZT-patiênten eveneens een sterk verhoogd renine vastgesteld. $\mathrm{Na}$ verwijdering van de supplementele zuurstof bleef de renine-spiegel gelijk, doch daalde het aldosteron significant.

De hierboven geschetste verbanden tussen ademhaling en circulatie bevestigen die welke in de literatuur vermeld worden. Er zijn echter een tweetal aspecten die nieuw zijn en waarvan de verklaring speculatief blijft. Onder de gekozen omstandigheden van normoxie en normale $\mathrm{pH}$ valt het verband tussen het arteriele $\mathrm{HCO}_{3}{ }^{-}$en de $\mathrm{FEV}_{1}$ vs de RPF op. Het verband tussen het $\mathrm{HCO}_{3}^{-}$en de RPF bereikte een grotere mate van significantie dan de relatie $\mathrm{PaCO}_{2}$ vs $\mathrm{RPF}$ (tabel 4.7). Het retineren van $\mathrm{HCO}_{3}$, met secundair water en natrium, vindt plaats ter hoogte van de proximale tubulus [Rose 1989]. De sterke relatie tussen de $\mathrm{FEV}_{1}$ en de RPF zou kunnen berusten op de mechanische invloed van de drukveranderingen in de long, of op een intermitterende daling van het slagvolume ten gevolge van geforceerde expiratie. Daarbij kan worden gedacht aan de invloed op de pre- en afterload van het rechter ventrikel. Drukverandering in de long, zoals ook bij positieve drukbeademing gezien wordt, belemmert de veneuze terugstroom en verhoogt de renale vaatweerstand.

Eveneens kan gedacht worden aan de secundaire gevolgen van de slechte longfunctie (hypoxie en/of hypercapnie) waardoor activatie van RAAS, de vaattonus en flow in de nier ongunstig beïnvloeden. 


\section{Effecten van nifedipine, vergeleken met die van placebo}

\subsection{Inleiding}

Het toepassen van vaatverwijdende stoffen is een succesrijke therapie bij patienten met arteriële hypertensie en decompensatio cordis [Huysmans en Thien 1989, Westerhof en Mensing 1989]. Bij pulmonale hypertensie zijn in het algemeen geen overtuigende resultaten beschreven.

Sedert de eerste publikaties over het gebruik van nifedipine bij acuut respiratoir falen [Simonneau et al 1981], is met name deze stof onder verschillende omstandigheden beproefd. De acute effecten van het middel lijken af te hangen van de ernst van de pulmonale hypertensie en de hypoxische vasoconstrictie. Bij stabiele patiënten met chronische hypoxie verlaagt nifedipine de pulmonalle vaatweerstand, soms zonder verandering in de mPAP [Singh el al 1985, Sturani et al 1987], soms ook met daling van de pulmonale arterièle druk [Saadjian et al 1987]. Andere onderzoekers hebben daarentegen gemeld dat nifedipine de pulmonale hypertensie kan doen toenemen, indien het middel acuut wordt gegeven [Johnsan et al 1986]. De plaats van zuurstof in combinatie met nifedipine is tot nu toe niet geheel afgebakend. Gelijktijdige toediening van zuurstof en nifedipine bij de stabiel hypoxische patiënt, met betrekking tot de daling van de mPAP, lijkt effectiever te zijn dan de toediening van elk apart [Kennedy et al 1984]. Anderzijds is door Italiaanse onderzoekers overtuigend aangetoond dat na één week nifedipine therapie bij hypoxische patiënten, zuurstof geen pulmonale vasodilatatie meer veroorzaakt. Op grond van deze resultaten ontraden $z i j$ de combinatietherapie [Agostoni et al 1989].

Gezien deze gegevens (pulmonale vasodilatatie door nifedipine onder hypoxische condities) enerzijds en de vaste plaats van OZT in de behandeling van het hypoxische cor pulmonale (met daardoor wellicht vermindering van pulmonale vasoconstrictie) anderzijds, vroegen wij ons af of nifedipine een additief effect zou hebben op de longcirculatie, indien deze stof zou worden toegediend aan patiènten die te voren reeds zuurstof hadden gekregen. Daartoe onderzochten wij de acute effecten van nifedipine op haemodynamiek (arterieel en pulmonaal) en gaswisseling bij 28 van de in het vorige hoofdstuk beschreven patienten. Bij 20 van hen werd zuurstof per neusslang toegediend om normoxie in rust te bereiken. Om een snel effect van nifedipine te verkrijgen werd een capsule van $10 \mathrm{mg}$ gegeven, waarvan de inhoud na doorbijten van de capsule, werd ingeslikt [McAllister 1985]. 
De effecten van nifedipine op de haemodynamiek en gaswisseling werden gemeten volgens het eerder beschreven schema.

Hoewel het op methodologische gronden wellicht juister was geweest om twee groepen patiënten te onderzoeken (placebogroep versus nifedipine-groep), kozen wij, gezien de invasieve meting en belasting voor de patiënt, voor een opzet waarbij iedere patiënt als zijn eigen controle zou dienen. Derhalve werden de metingen uitgevoerd na placebo- en na nifedipine-toediening, zoals eerder weergegeven in het schema in hoofdstuk 3.

Achtereenvolgens worden hier besproken: de uitgangswaarden in de placebofase, de acute effecten van nifedipine na de placebofase, de verbanden tussen de arteriële en de pulmonale effecten van nifedipine en ten slotte twee subgroepanalyses om de invloed vast te stellen van pulmonale hypertensie en hypercapnie op de effecten van nifedipinetoediening.

\subsection{Uitgangswaarden}

De uitgangswaarden van de 28 patiënten zijn samengevat in tabel 5.1. De karakteristieken, voorafgaande aan toediening van de vaatverwijder, komen overeen met die van de grotere groep. Er is sprake van een normale perifere vaatweerstand in relatie tot het hartminuutvolume en een laag normale capillaire wiggedruk. De hartminuutvolume-index bleek slechts verlaagd in 2 patiënten terwijl de slagvolume-index gemiddeld normaal uitviel (36 $\pm 9 \mathrm{ml} . \mathrm{slag}^{-1}$, normaal 30-45). De patiènten met tekenen van ernstige luchtwegobstructie vertoonden matig verhoogde drukken en weerstanden in het pulmonale vaatbed, waarbij de gemiddelde arbeidsindices van linker en rechter ventrikel binnen de norm waren. Indien voor de RVSWI een normaalwaarde tot $12 \mathrm{~g} \cdot \mathrm{m}^{-2}$ wordt aangenomen, dan is de RVSWI bij 11 van de 28 patiënten verhoogd. Bij de arteriële gaswaardenbepaling werd bij 14 patiënten een milde hypercapnie gevonden.

\subsection{Resultaten}

De resultaten van de, in de placebo- en actieve fase verrichte, metingen zijn weergegeven in de figuren $5.1 \mathrm{t} / \mathrm{m} 5.4$ en tabel 5.2. Aan het eind van de placebofase werden met betrekking tot de haemodynamiek en gaswisseling geen veranderingen vastgesteld ten opzichte van de uitgangswaarde in de voorafgaande stabilisatiefase. 
Tabel 5.1: Uitgangswaarden bij 28 patienten voonafgand aan nifedipine-toediening.

\begin{tabular}{|c|c|c|}
\hline variabele & eenheid & uîtgangswharde \\
\hline leeftijd & (jaren) & $68 \pm 8$ \\
\hline $\mathrm{Hb}$ & (mmol. $\left.{ }^{-1}\right)$ & $10.1 \pm 0.9$ \\
\hline $\mathrm{Ht}$ & $\left(1.1^{-11}\right)$ & $0.50 \pm 0.04$ \\
\hline $\mathrm{FEV}_{1}$ & (l) & $0.82 \pm 0.17$ \\
\hline $\mathrm{FEV}_{1} / \mathrm{FVC}$ & $(\%)$ & $35 \pm 10$ \\
\hline MAP & $(\mathrm{mmHg})$ & $93 \pm 13$ \\
\hline mPAP & $(\mathrm{mmHg})$ & $22 \pm 8$ \\
\hline RAP & $(\mathrm{mmHg})$ & $3 \pm 3$ \\
\hline PCWP & $(\mathrm{mmHg})$ & $6 \pm 3$ \\
\hline $\mathrm{HF}$ & (slagen $\min ^{-1}$ ) & $89 \pm 14$ \\
\hline $\mathrm{CO}$ & $\left(\operatorname{minin}^{-1}\right)$ & $5.5 \pm 1.3$ \\
\hline SV & $\left(\mathrm{mll} . \mathrm{slag}^{-1}\right)$ & $63 \pm 17$ \\
\hline SVR & $\left(\right.$ dyne $\left.\sec \mathrm{cm}^{-5}\right)$ & $1361 \pm 327$ \\
\hline PVR & $\left(\right.$ dyne $\left.\sec \mathrm{cm}^{-5}\right)$ & $240 \pm 121$ \\
\hline LVSWI & $\left(\mathrm{g} \cdot \mathrm{m}^{-2}\right)$ & $45 \pm 12$ \\
\hline RVSWI & $\left(g \cdot m^{-2}\right)$ & $11 \pm 4$ \\
\hline $\mathrm{PaO}_{2}$ & $(\mathrm{mmHg})$ & $72 \pm 16$ \\
\hline $\mathrm{PaCO}_{2}$ & $(\mathrm{mmHg})$ & $46 \pm 8$ \\
\hline $\mathrm{PvO}_{2}$ & $(\mathrm{mmHg})$ & $38 \pm 4$ \\
\hline shunt & $(\%)$ & $23 \pm 10$ \\
\hline SOT & $\left(\mathrm{mllmin}{ }^{-1}\right)$ & $1142 \pm 306$ \\
\hline $\mathrm{VO}_{2}$ & $\left(\mathrm{ml} \mathrm{min}^{-1}\right)$ & $279 \pm 69$ \\
\hline
\end{tabular}

Nifedipine daarentegen veroorzaakte een forse daling van de bloeddruk en perifere vaatweerstand bij een stijging van het hartminuutwolume. De vullingsdrukken (RAP en PCWP) bleven volledig ongewijzigd evenals de druk in de pulmonaal arteriën.

\subsubsection{Systemische effecten van nifedipine}

Vijf minuten na toediening van nifedipine werd reeds een daling van de MAP en de SVR vastgesteld, welke aanhield tot 60 minuten na de gift. In vergelijking tot de uitgangswaarde daalde de SVR met 27\%, van $1361 \pm 327$ naar $987 \pm 161$ dyne.sec.cm ${ }^{-5}, \mathrm{p}<0.005$ na 15 minuten en naar $991 \pm 239$ dyne.sec.cm ${ }^{-5}, \mathrm{p}<0.005$ na 60 minuten. De MAP daalde significant vanaf 15 minuten ( $v a n 92 \pm 13$ naar $80 \pm 13 \mathrm{mmHg}, \mathrm{p}<0.005$, daling met $13 \%$ ) 
Fuguur 5.1: Effecten van nifedipine op $\mathrm{Cl}$, MAP en ImPAP (placebocontrole).
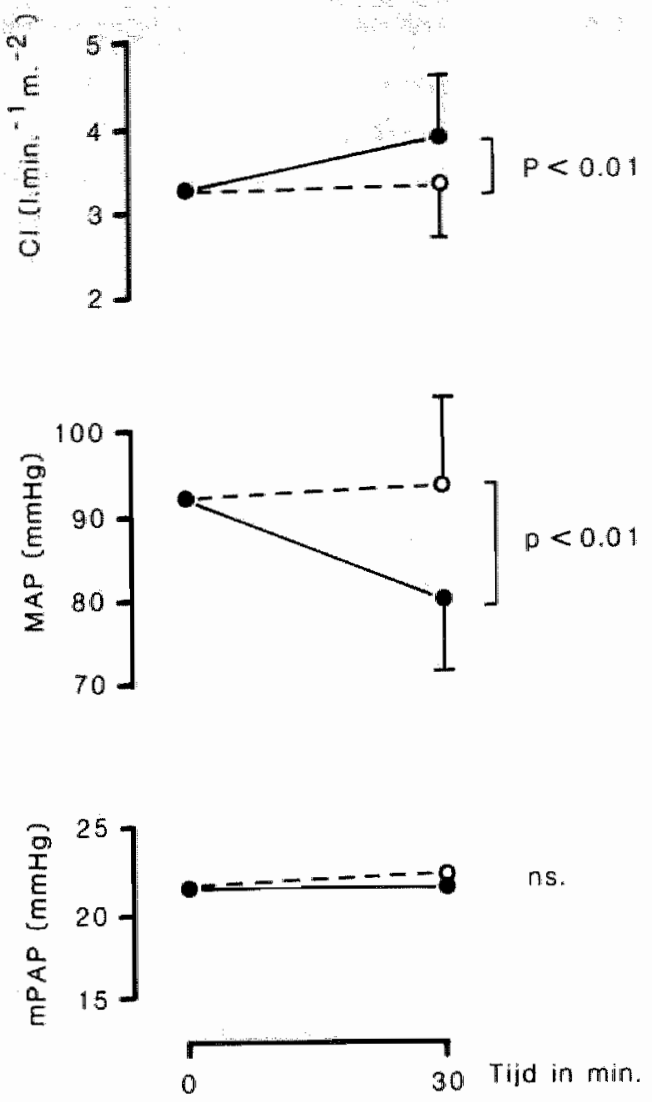

- Placebo fase

- Actieve lase

en bleef gehandhaafd 30 en 60 minuten na toediening. Het hartminuutvolume nam toe $(\mathrm{Cl}$ steeg van $3.2 \pm 0.6$ naar $3.7 \pm 0.7 \mathrm{l}$.min. $\mathrm{m}^{-2}, \mathrm{p}<0.005$ na 15 minuten) en bleef tot 60 minuten na toediening verhoogd. De hartfrequentie werd nauwelijks beïnvloed door nifedipine. Een maximalle versnelling van 4 slagen.min ${ }^{-1}$ werd waargenomen na 15 en 30 minuten (van $89 \pm 14$ naar $93 \pm 14$ slagen.min ${ }^{-1}, p=N S$ ). Daarentegen veroorzaakte het medicament een stijging van het slagvolume (met $17 \%$ na 30 en 60 minuten, van $63 \pm 17$ tot $74 \pm 18$ ml.slag, $p=N S$ ). De arbeidsindex van het linker ventrikel bleef ongewijzigd (45 
Figuur 5.2: Effecten van nifedipine op de MAP en mPAP.

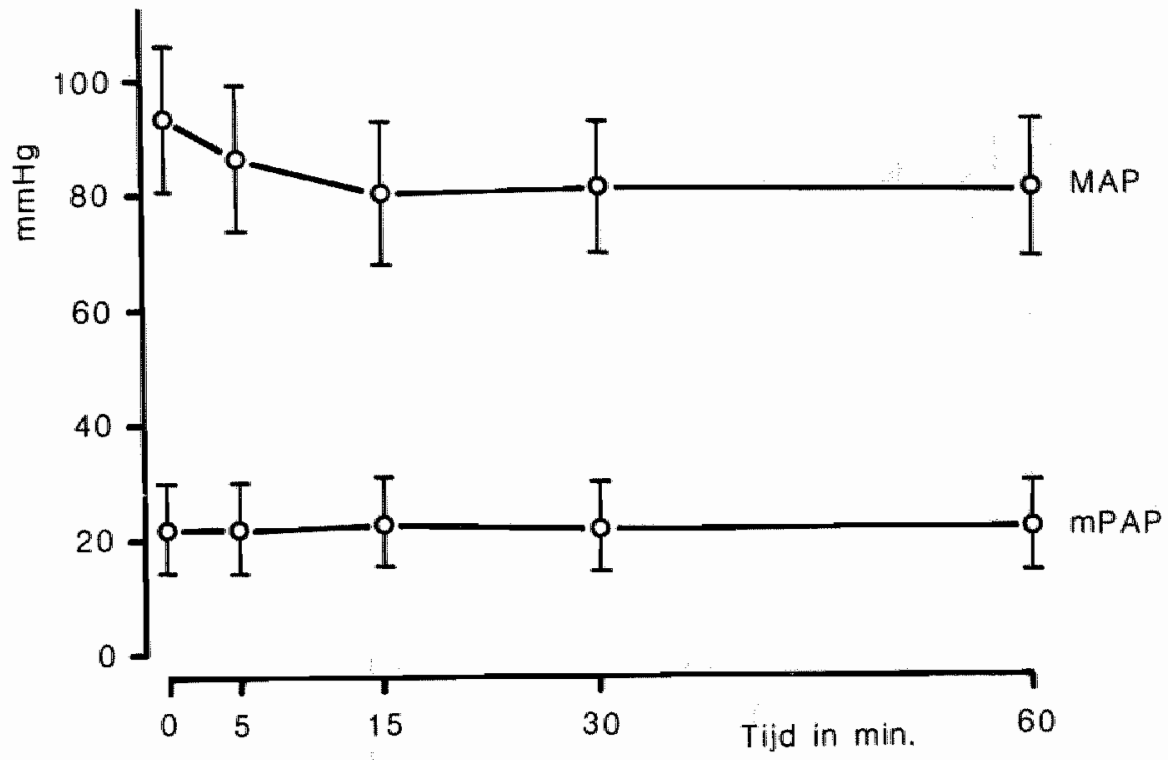

Figuur 5.3: Effecten van nifedipine op de hartminuutwolume-index.

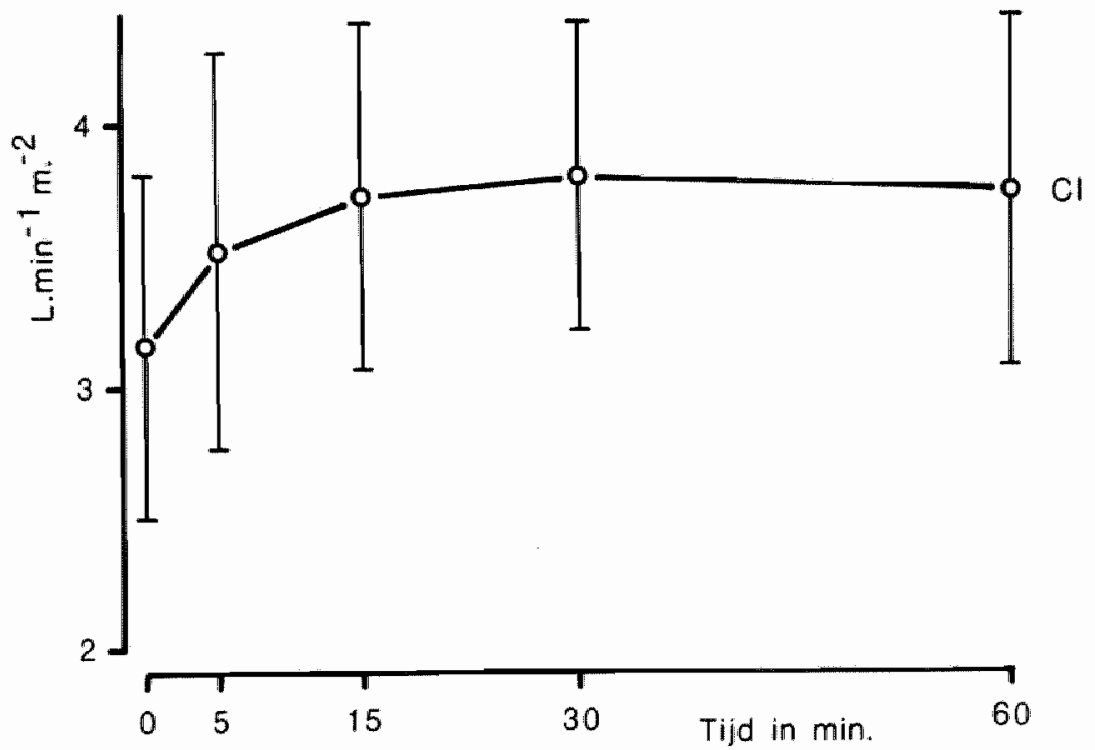


Figurur 5.4: Effecten van mifedipine op de SVR en PVR.

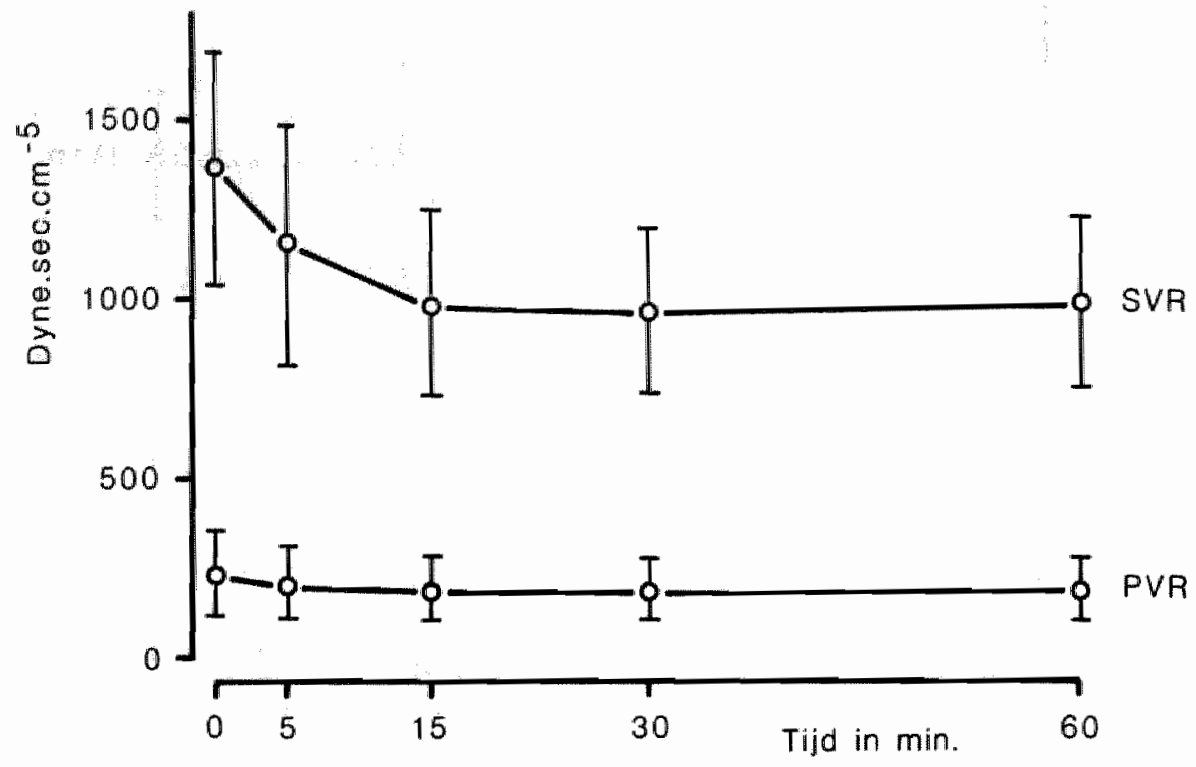

\pm 12 naar respectievelijk $45 \pm 12 \mathrm{~g} \cdot \mathrm{m}^{-2}$ en $47 \pm 13 \mathrm{~g} \cdot \mathrm{m}^{-2}$ na 15 en 60 minuten, $\left.\mathrm{p}=\mathrm{NS}\right)$. De wiggedruk bleef eveneens stabiel.

\subsubsection{Pulmonale effecten van nifedipine}

In tegenstelling tot die in arterièle bloeddruk en vaatweerstand waren de veranderingen in het pulmonale vaatbed weinig uitgesproken. De mPAP was vrijwel constant over het gehele tijdstraject (van mPAP $22 \pm 8$ basaal, naar $23 \pm 8$ na 15 minuten en $23 \pm 8 \mathrm{mmHg}$ na 60 minuten, $p=N S$ ), evenals het verschil tussen de mPAP en de wiggedruk. Doordat de $\mathrm{Cl}$ wel was gestegen, werd dientengevolge een daling berekend in de pulmonale vaatweerstand ( $v a n$ $240 \pm 121$ natar $193 \pm 90$ dyne.sec.cm ${ }^{-5}, \mathrm{p}=$ NS na 15 minuten). Indien de daling in de PVR wordt weergegeven als de procentuele daling ten opzichte van de uitgangswaarde, is het verschil significant $(-16 \pm 16 \%$ na 15 en 30 minuten, $p<0.001)$.

De geünduceerde veranderingen in $\mathrm{CI}$ en $\mathrm{PVR}$ resulteerden in een geringe toename van de arbeidsindex van het rechter ventrikel (van $11 \pm 4$ naar $13 \pm 6 \mathrm{~g} \cdot \mathrm{m}^{-2}, \mathrm{p}=\mathrm{NS}$ ) na 15 minuten. 
Tabel 5.2: Gaswaarden en zuurstoftransport woor en 15 en 60 minuten na nifedïpinetoediening.

\begin{tabular}{lccc}
\hline & basaal & $\begin{array}{c}\text { 15 minuten na } \\
\text { nifedipine }\end{array}$ & $\begin{array}{c}60 \text { minuten na } \\
\text { nifedipine }\end{array}$ \\
\hline $\mathrm{PaO}_{2}$ & $72 \pm 16$ & $72 \pm 15$ & $71 \pm 15$ \\
$\mathrm{PaCO}_{2}$ & $46 \pm 8$ & $46 \pm 9$ & $45 \pm 8$ \\
$\mathrm{PvO}_{2}$ & $38 \pm 4$ & $40 \pm 4$ & $39 \pm 4$ \\
$\mathrm{SvO}_{2}$ & $70 \pm 5$ & $73 \pm 4^{\circ}$ & $71 \pm 5$ \\
shumt & $24 \pm 10$ & $26 \pm 13$ & $25 \pm 11$ \\
$\mathrm{SOT}$ & $1142 \pm 306$ & $1303 \pm 297$ & $1344 \pm 310$ \\
$\mathrm{VO}_{2}$ & $279 \pm 69$ & $286 \pm 83$ & $311 \pm 74$ \\
\hline p< & & \\
\hline
\end{tabular}

\subsubsection{Invloed van nifedipine op de gaswaarden}

De arteriële gaswaarden veranderden nauwelijks (tabel 5.2). Het zuurstoftransport nam toe; door het stijgende hartminuutvolume steeg de SOT met maximaal 18\% (van $1142 \pm 306$ naar $1344 \pm 310 \mathrm{ml} . \mathrm{min}, \mathrm{p}<0.05)$ na 60 minuten. Tijdens de vergroting van het aanbod trad een geringe stijging op in het verbruik $\left(\mathrm{VO}_{2}\right.$ van $279 \pm 69$ naar $311 \pm 74 \mathrm{ml}$ min na 60 minuten, $\mathrm{p}=\mathrm{NS}$ ) van $10 \%$. De veneuze bijmenging in het pulmonale vaatbed veranderde niet. De kleine stijging in de shuntfractie als gevolg van de stijging in het hartminuntvolume veroorzaakte een geringe stijging in de gemengd veneuze $\mathrm{O}_{2}$-spanning $\left(\mathrm{PvO}_{2}\right.$ na 15 minuten van $38 \pm 4$ naar $40 \pm 4 \mathrm{mmHg}, \mathrm{p}=\mathrm{NS})$ en de gemengd veneuze saturatie $\left(\mathrm{SvO}_{2}\right.$ van $70 \pm$ 5 natar $73 \pm 4 \mathrm{mmHg}$, $p<0.05$ ). Er trad een minimale daling op van de $\mathrm{PaO}_{2}$.

\subsubsection{Betekenis van pulmonale hypertensie of hypercapnie voor de reactie op nifedipine}

Subgroep analyse werd werricht om te bepalen of pulmonale hypertensie of hypercapnie het effect van nifedipine zouden moduleren. De aanwezigheid van pulmonale hypertensie bij 14 van de 28 patiënten bleek de effecten van nifedipine nauwelijks te beïnvloeden (tabe) 5.3 ). Hoewel de procentuele wijzigingen ten opzichte van de uitgangswaarde significant waren, werd met betrekking tot het werloop van de haemodynamische variabelen in de subgroepen geen werschil waargenomen. Slechts met betrekking tot de $\mathrm{PaO}_{2}$ en de veneuze bijmenging was een gering effect aantoonbaar (figuren 5.5 en 5.6). Hoewel de verschillen klein zijn en 
Figuur 5.5: Inwloeden van nifedipine op de $\mathrm{PaO}_{2}$

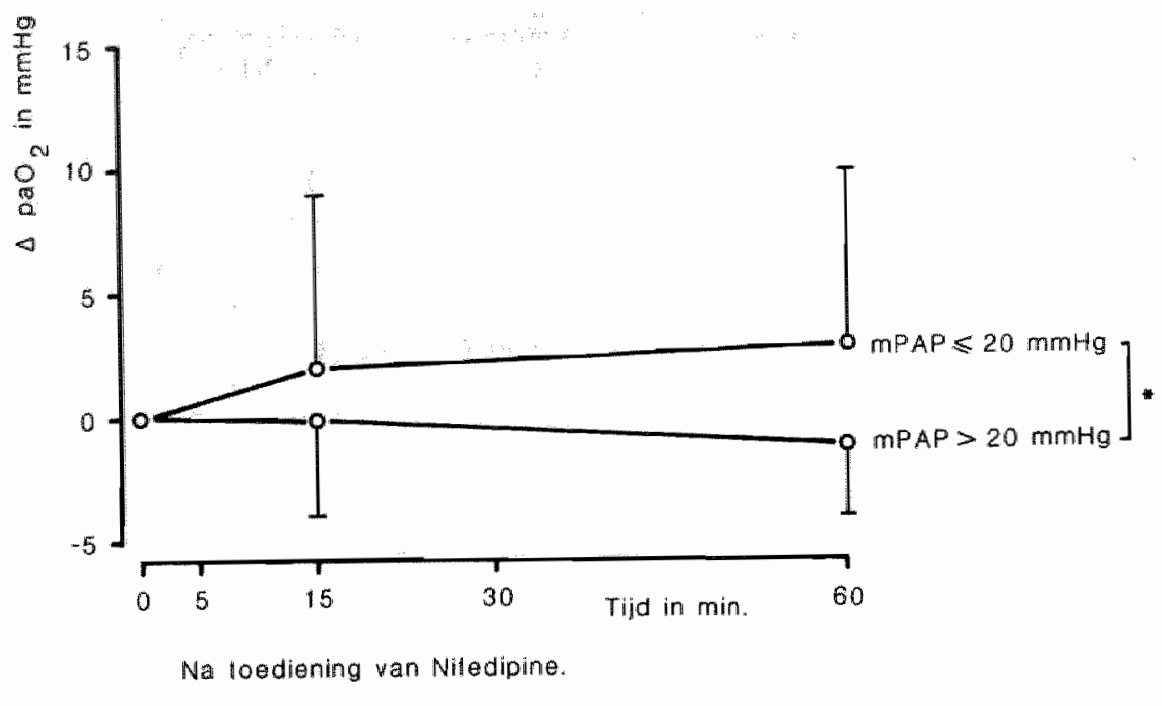

$* 0.05<p<0.10$

Tabel 5.3: Procentuele veranderingen in diverse variabelen, 15 en 60 minuten na nifedipinetoediening. De veranderingen in $\mathrm{PaO}_{2}$ en shunt zijn weergegeven in absolute hoeveelheden.

\begin{tabular}{|c|c|c|c|c|}
\hline \multirow[t]{2}{*}{ variabele } & \multicolumn{2}{|c|}{$m P A P \leq 20 \mathrm{mmHg}(n=14)$} & \multicolumn{2}{|c|}{$\mathrm{mPAP}>20 \mathrm{mmHg}(\mathrm{n}=14)$} \\
\hline & 15 minuten & 60 minuten & 15 minuten & 60 minuten \\
\hline MAP & $-13 \pm 10$ & $-11 \pm 9 *$ & $-14 \pm 10 * *$ & $-14 \pm 10^{* * * *}$ \\
\hline mPAP & $3 \pm 9$ & $1 \pm 10$ & $1 \pm 12$ & $2 \pm 11$ \\
\hline SVR & $-26 \pm 11 \cdots$ & $-24 \pm 15 *$ & $-27 \pm 10^{* * *}$ & $-26 \pm 14 * * *$ \\
\hline PVR & $-15 \pm 21$ & $. .17 \pm 18$ & $-17 \pm 14$ & $-13 \pm 16$ \\
\hline $\mathrm{CI}$ & $18 \pm 10^{* * *}$ & $20 \pm 19 * * *$ & $19 \pm 11 * * * * *$ & 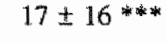 \\
\hline $\mathrm{PaO}_{2}$ & $2 \pm 7$ & $3 \pm 7$ & $0 \pm 3$ & $-1 \pm 3$ \\
\hline shunt & $2 \pm 9$ & $-1 \pm 8$ & $4 \pm 7 *$ & $4 \pm 5$ \\
\hline SOT & $15 \pm 15$ & $17 \pm 21 *$ & $20 \pm 14 * * *$ & $18 \pm 16 * *$ \\
\hline $\mathrm{VO}_{2}$ & $3 \pm 18$ & $14 \pm 21$ & $4 \pm 18$ & $10 \pm 22$ \\
\hline
\end{tabular}


Figuur 5.6: Invloeden wan nifedipine op de veneuze bijmenging in functie van de mPAP.

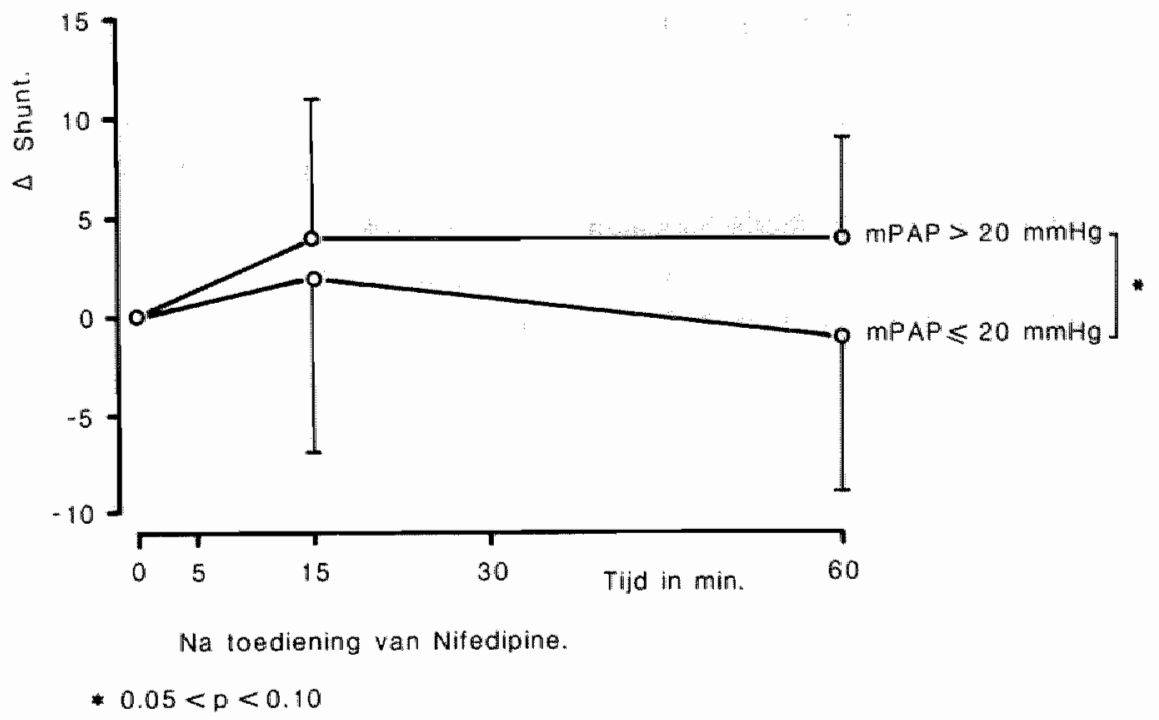

Tabell 5.4: Procentuele veranderingen 15 en 60 minuten na nifedipinetoediening, in relatie tot het initiele arteriele $\mathrm{CO}_{2}$-gehalte. De wijzigingen in de $\mathrm{PaO}_{2}$ en de shunt zijn weergegeven als absolute hoeveelheden.

\begin{tabular}{lcccc}
\hline variabele & \multicolumn{2}{c}{$\mathrm{PaCO}_{2} \leq 45 \mathrm{mmHg}(\mathrm{n}=14)$} & \multicolumn{2}{c}{$\mathrm{PaCO}_{2}>45 \mathrm{mmHg}(\mathrm{n}=\mathbb{1 4})$} \\
& 15 minuten & 60 minuten & 15 minuten & 60 minuten \\
\hline MAP & $-13 \pm 7 * * *$ & $-13 \pm 8^{* * *}$ & $-14 \pm 13 * * *$ & $-13 \pm 13 * * *$ \\
mPAP & $4 \pm 10$ & $1 \pm 9$ & $-1 \pm 12$ & $3 \pm 12$ \\
SVR & $-28 \pm 10^{* * *}$ & $-26 \pm 13^{* * *}$ & $-26 \pm 12 * * *$ & $-24 \pm 17 * * *$ \\
$\mathrm{PVR}$ & $-18 \pm 16^{* *}$ & $-17 \pm 18^{*}$ & $-14 \pm 15$ & $-13 \pm 15$ \\
$\mathrm{CI}$ & $21 \pm 12^{* * *}$ & $20 \pm 18 * * *$ & $16 \pm 9 * *$ & $17 \pm 16 * * *$ \\
& & & & \\
$\mathrm{PaO}_{2}$ & $-1 \pm 6$ & $0 \pm 6$ & $2 \pm 4$ & $1 \pm 4$ \\
$\mathrm{Shunt}^{\mathrm{SOT}}$ & $5 \pm 8$ & $2 \pm 8$ & $1 \pm 5$ & $2 \pm 5$ \\
$\mathrm{SO}_{2}$ & $18 \pm 17 * * *$ & $19 \pm 19 * * *$ & $16 \pm 9 * *$ & $16 \pm 17 * * *$ \\
& $3 \pm 18$ & $14 \pm 23$ & $5 \pm 18$ & $10 \pm 18$
\end{tabular}

De significanties (* $p<0.05, * * p<0.01$, *** $p<0.005)$ zijn weergegeven, volgens de gepaarde t-test, ten opzichte van de basale waarden. 
waarschijnlijk klinisch niet zo relevant, suggereren de resultaten dat bij de patiënten met pulmonale hypertensie, ondanks zuurstoftoediening, meer longgebieden met slechte ventilatie en/of perfusie reageren op nifedipine.

Hypercapnie $\left(\mathrm{PaCO}_{2}>45 \mathrm{mmHg}\right.$ ) werd vastgesteld bij 14 van de 28 patiënten. In de groep met hypercapnie bleek, conform de bevindingen uit hoofdstuk 4, de SVR lager te zijn en de CI hoger dan in de resterende patiënten (respectievelijk $1193 \pm 281$ vs $1500 \pm 301$ dyne.sec.cm ${ }^{-5}, p<0.01$ en $3.48 \pm 0.64$ vs $2.90 \pm 0.571 . \mathrm{min}^{-1} . \mathrm{m}^{-2}$, $\mathrm{p}<0.05$ ). Het beloop van de MAP, mPAP en SVR na nifedipine bleek echter identiek in beide groepen (tabel 5.4). Met betrekking tot de verandering in PVR, bleek in de groep met normocapnie een iets sterkere daling op te treden (na 15 minuten -18 vs $-14 \%$ en na 50 minuten -17 vs $-13 \%, \mathrm{p}$ $=0.09$ ). Het klinisch belang van deze bevinding lijkt echter niet groot, gezien de kleine verschillen.

\subsection{Bespreking}

Door Rubin zijn drie vragen naar voren gebracht met betrekking tot de plaats van vaatverwijders bij het obstructief longlijden [Rubin 1987]:

1. Is specifieke pulmonale vasodilatatie mogelijk?

2. Zijn er groepen patiènten die in het bijzonder profiteren of juist nadelige invloeden ondervinden van vaatverwijders?

3. Hebben vaatverwijders invloed op de overleving?

Indien de hier gepresenteercle gegevens tegen deze achtergrond worden beoordeeld, is duidelijk dat nifedipine als adjuvans, naast $\mathrm{OZT}$, vooral systemische effecten veroorzaakt en nauwelijks invloed heeft op de pulmonale haemodynamiek.

De resultaten met betrekking tot de haemodynamiek en gaswisseling worden vergeleken met literatuurgegevens over acute en langere-termijneffecten van calcium-antagonisten, welke zijn samengevat in tabel 5.5 en 5.6. De waargenomen veranderingen in de bloeddruk, de perifere vaatweerstand en het hartminuutvolume komen overeen met de bevindingen uit tabel 5.5. Enkele onderzoekers stelden een significante stijging vast van de wiggedruk na toediening van nifedipine [Sturani, Johnson], geduid als een mild negatief inotroop effect of een gevolg van de toename in hartminuutvolume. Dit komt in onze gegevens niet naar voren, evenmin als een verband tussen de mate van bloeddrukreductie en de initiële $\mathrm{PaO}_{2}$, zoals gesuggereerd voor de effecten van ACE-remmers [Bertoli 1986]. 
Tabel 5.5: Acute effecten van calcium-antagonisten op de haemodynamiek en gaswisseling bij stabiele patięnten met obstructief longlijden.

\begin{tabular}{|c|c|c|c|c|c|c|c|c|}
\hline auteur & therapie & n & $\begin{array}{c}\mathrm{PaO}_{2} \\
(\mathrm{mmHg})\end{array}$ & $\underset{(\mathrm{mmHg})}{\Delta \mathrm{PaO}_{\mathrm{a}}}$ & $\begin{array}{c}\Delta \mathrm{CI} \\
\left(1 . \mathrm{min}^{-1} \cdot \mathrm{m}^{-2}\right)\end{array}$ & $\underset{(\mathrm{mmHg})}{\mathrm{mPAP}}$ & $\begin{array}{l}\triangle \mathrm{MmPAP} \\
(\mathrm{mmHg})\end{array}$ & $\begin{array}{l}\triangle \mathrm{MAP} \\
(\text { (ummHg) }\end{array}$ \\
\hline $\begin{array}{l}\text { Sturani } \\
1987\end{array}$ & $\begin{array}{l}\text { nifedipine } \\
20 \mathrm{mg}\end{array}$ & 12 & 51 & 0 & $+0.9^{*}$ & 42 & .2 & $-16 *$ \\
\hline $\begin{array}{l}\text { Kennedy } \\
1984\end{array}$ & $\begin{array}{l}\text { nifedipine } \\
40 \mathrm{mg}\end{array}$ & 6 & 51 & $-4 *$ & $+0.5 *$ & 38 & $-3 *$ & -11 \\
\hline $\begin{array}{l}\text { Singh } \\
1985\end{array}$ & $\begin{array}{l}\text { nifedipine } \\
20 \mathrm{mg}\end{array}$ & 8 & 48 & -1 & $+0.4^{*}$ & 41 & -2 & $-13 *$ \\
\hline $\begin{array}{l}\text { Agostoni } \\
1989\end{array}$ & $\begin{array}{l}\text { nifedipine } \\
6 \times 30 \mathrm{mg}\end{array}$ & 15 & 55 & 0 & +0.6 & 33 & $-6^{*}$ & $-10 *$ \\
\hline $\begin{array}{l}\text { Johnson } \\
1986\end{array}$ & $\begin{array}{l}\text { nifedipine } \\
20 \mathrm{mg}\end{array}$ & 10 & 55 & $-7 *$ & $+0.2 *$ & 30 & $+4 *$ & $-10 *$ \\
\hline $\begin{array}{l}\text { Mols } \\
1986\end{array}$ & $\begin{array}{l}\text { nitrendipine } \\
20 \mathrm{mg}\end{array}$ & 10 & 71 & -3 & $+0.50 *$ & 17 & +1 & $.11 *$ \\
\hline Dees & $\begin{array}{l}\text { nifedipine } \\
10 \mathrm{mg}\end{array}$ & 28 & 72 & -1 & $+0.50 *$ & 22 & +1 & $.12 *$ \\
\hline
\end{tabular}

- Significante verandering t.0.v. de uingangswaarde ( $p \leq 0.05)$.

1 In deze studlie werd nifedipine $\mathbb{1}$ week toegediend.

Tabel 5.6: Chronische effecten van calcium×antagonisten op de haemodynamick en gaswisseling bij stabiele patiènten met obstructief longlijden.

\begin{tabular}{|c|c|c|c|c|c|c|c|c|c|}
\hline auteur & therapie & $\mathbf{n}$ & observatie & $\underset{(\mathrm{mmHg})}{\mathrm{PaO}_{3}}$ & $\begin{array}{c}\triangle \mathrm{PaO}_{2} \\
(\mathrm{mmHg})\end{array}$ & $\underset{\left(1 \cdot \mathrm{min}^{-1} \cdot \mathrm{m}^{2}\right)}{\Delta \mathrm{CI}}$ & $\begin{array}{c}\operatorname{mPAP} \\
(\mathrm{mmHg})\end{array}$ & $\begin{array}{l}\triangle \mathrm{MmPAP} \\
(\mathrm{mmHg})\end{array}$ & $\begin{array}{l}\triangle \mathrm{MAP}^{\mathrm{A}} \\
(\mathrm{mmHg})\end{array}$ \\
\hline $\begin{array}{l}\text { Bratel } \\
1986\end{array}$ & $\begin{array}{l}\text { felodipine } \\
2 \times 20 \mathrm{mg}\end{array}$ & 9 & $3.5 \mathrm{mnd}$ & 66 & $-5 *$ & +0.6 & 22 & +1 & -6 \\
\hline $\begin{array}{l}\text { Sturani } \\
1987\end{array}$ & $\begin{array}{l}\text { nifedipine } \\
3 \times 10-20 \mathrm{mg}\end{array}$ & 8 & $8 w k n$ & 51 & $-2 *$ & +0.2 & 42 & $.7 \%$ & $.9^{*}$ \\
\hline $\begin{array}{l}\text { Agostoni } \\
1989\end{array}$ & $\begin{array}{l}\text { nifedipine } \\
6 \times 30 \mathrm{mg}\end{array}$ & 10 & $8 \mathrm{wkn}$ & 55 & 0 & $+0.2 *$ & 33 & -1 & $-14 *$ \\
\hline $\begin{array}{l}\text { Jolunson } \\
1986\end{array}$ & $\begin{array}{l}\text { nifedipine } \\
2 \times 20 \mathrm{mg}\end{array}$ & 10 & 3. $\mathrm{mnd}$ & 55 & 0 & 0 & 30 & -1 & -2 \\
\hline $\begin{array}{l}\text { Rubin } \\
1986\end{array}$ & nitrendipine & 8 & $6 w k n$ & 53 & -8 & $+12 *$ & 40 & $.9 *$ & .1 \\
\hline
\end{tabular}


De invloed van nifedipine op de pulmonale haemodynamiek was gering. Zo werd na 15 minuten bij alle patiënten ondanks een daling van de MAP en SVR geen verandering in mPAP vastgesteld. De resultaten uit de lange-termijnstudies (tabel 5.6) geven in 2 van de 5 studies een significante daling te zien van de mPAP. In beide onderzoeken was de initièle mPAP hoog ( 42 en $40 \mathrm{mmHg}$ respectievelijk). Een bezwaar tegen deze studies is echter het kleine aantal patiënten en het feit dat in het onderzoek van Rubin de hartminuutvolumeindex bij aanvang was verlaagd, hetgeen zou kunnen wijzen op een verminderde linkerventrikelfunctie en tevens de verbetering van de haemodynamiek door afterload-verlaging zou kumnen verklaren. Voorts dient te worden opgemerkt dat, met uitzondering van de studie van Rubin, de patiënten uit de studies werden onderzocht tijdens hypoxie, in tegenstelling tot onze patiënten.

In het oorspronkelijke onderzoek van Simonneau werd nifedipine toegediend bij hypoxische patiënten gedurende een exacerbatie van hun chronisch obstructief longlijden. Bij een actieve vasodilatatie van het pulmonale vaatbed werd een lineair verband gevonden tussen de daling in PVR en de initielle $\mathrm{PaO}_{2}$ [Simonneau et al 1981]. De latere studies (tabel 5.5) met stabiele hypoxische patiënten hebben een dergelijke relatie niet bevestigd, evenmin als onze resultaten $\left(\mathrm{PaO}_{2}\right.$ vs $\triangle \mathrm{PVR}$ na 60 minuten, $\left.\mathrm{p}=0.96\right)$.

De vraag komt naar voren of een klinisch vastgestelde daling in de PVR niet meer een rekenkundig gewolg is van het veranderde hartminuutvolume, dan een weergave van actieve vasodilatatie [McGregor en Sniderman 1985]. Door gebruik te maken van pressure-/flow-grafieken (perfusiedruk vs hartminuutvolume-index) op verschillende momenten, kan een nauwkeurige indruk worden verkregen [Agostoni et al 1989]. Bij onze patiënten was er sprake van een constante perfusiedruk in het longvaatbed, bij een stabiele mPAP en wiggedruk. Men kan zich voorstellen dat ten gevolge van de perifere weerstandsdaling en bloeddrukdaling het hartminuutvolume en de mPAP stijgen, waardoor de PVR gaat dalen en de mPAP normaliseert met constant blijven van de perfusiedruk. Eerdere studies met directe vaatverwijders als hydralazine, passen in het concept van stijging van het hartminuutvolume en mPAP [Lupi-Herrera et al 1984]. Anderzijds kan een primair effect op de PVR, leidend tot stijging van het hartminuutvolume, niet worden uitgesloten.

De invloeden van nifedipine op de gaswaarden bevestigen literatuurgegevens waarin geen verandering, of soms een daling in $\mathrm{PaO}_{2}$, wordt gezien. Onze onderzoeksopzet, waarbij nifedipine additief werd gegeven aan zuurstoftoediening, voorkomt dat er grove schommelingen optreden in de shuntractie, zoals die werden waargenomen in eerdere 
studies [Kalra en Bone 1989]. Het gelijkblijvende $\mathrm{PaCO}_{2}$-gehalte wijst er verder op dat er geen sprake was van compensatoire ademhalingsbewegingen om een $\mathrm{PaO}_{2}$-daling te couperen.

De aanwezigheid van pulmonale hypertensie en/of hypercapnie heeft, tijdens nomoxie, slechts een marginale invloed op de effecten van nifedipine. De lange-termijneffecten van nifedipine, als adjuxante therapie, zijn nog onvoldoende bekend. 


\section{$6 \quad$ Nifedipine versus captopril}

\subsection{Inleiding}

In het vorige hoofdstuk zijn de effecten beschreven van nifedipine op haemodynamiek en gaswisseling bij patiënten met chronisch obstructief longlijden. Daarbij is naar voren gekomen dat dit middel onder condities van normoxie geen noemenswaardig effect heeft op pulmonale circulatie en zelfs de gaswisseling nadelig beïnvloedt door toeneming van de shuntfractie. Het is echter de vraag of met andere typen van vaatverwijdende medicamenten eensluidende resultaten worden verkregen. Om dit te onderzoeken vergeleken wij de effecten van nifedipine met die van de angiotensine converting enzyme (ACE-)remmer captopril. Daarbij is niet alleen gekeken naar de veranderingen in de algemene en pulmonale haemodynamiek, maar ook naar veranderingen in niercirculatie en pressorhormonen.

De reden voor de keuze van deze vaatverwijders wordt gevormd door het feit dat nifedipine als pure arteriële vaatverwijder werkt en captopril, zoals ACE-remmers in het algemeen, als gemengd-arterieel-veneuze vaatverwijder [Packer 1986]. Het feit dat beide klassen van vaatverwijders, ACE-remmers en calcium-antagonisten, natriuretische eigenschappen bezitten, maakt hen tevens geschikt voor verder onderzoek bij patiënten met het secundaire

Talbel 6.1: Uitgangswaarden bij 12 patienten met ernstig obstructief longlijden, voorafgand aan nifedipine- of captoprilinterventie.

\begin{tabular}{|c|c|c|c|c|}
\hline variablele & eenheid & $\begin{array}{l}\text { nifedipinegroep } \\
\qquad(\mathrm{n}=6)\end{array}$ & $\begin{array}{c}\text { captoprilgroep } \\
(\mathrm{n}=6)\end{array}$ & p \\
\hline leeftijd & (jaren) & $64 \pm 7$ & $66 \pm 11$ & NS \\
\hline lichaamsoppervlak & $\left(m^{2}\right)$ & $1.73 \pm 0.16$ & $1.67 \pm 0.19$ & NS \\
\hline $\mathrm{Hb}$ & $\left(\mathrm{mmol} \|^{1-1}\right)$ & $10.2 \pm 0.9$ & $9.3 \pm 1.6$ & NS \\
\hline$F E V_{1}$ & (1) & $1.01 \pm 0.07$ & $0.87 \pm 0.43$ & $\mathrm{NS}$ \\
\hline $\mathrm{FEV}_{\mathrm{i}} / \mathrm{FVC}$ & $(\%)$ & $0.41 \pm 0.14$ & $0.39 \pm 0.08$ & $N S$ \\
\hline $\mathrm{PaO}_{2}$ & $(\mathrm{mmHF})$ & $80 \pm 23$ & $81 \pm 24$ & NS \\
\hline $\mathrm{PaCO}_{2}$ & $(\mathrm{mmHg})$ & $42 \pm 4$ & $45 \pm 6$ & NS \\
\hline $\mathrm{PvO}_{2}$ & $(\mathrm{mmHg})$ & $38 \pm 4$ & $34 \pm 3$ & $0.05<p<0.10$ \\
\hline shunt & $(\%)$ & $19 \pm 10$ & $17 \pm 7$ & NS \\
\hline SOT & $\left(\mathrm{ml} \cdot \mathrm{min}^{-1}\right)$ & $1252 \pm 236$ & $946 \pm 387$ & NS \\
\hline $\mathrm{VO}_{2}$ & $\left(\mathrm{mllmin}^{-1}\right)$ & $311 \pm 49$ & $300 \pm 134$ & NS \\
\hline
\end{tabular}


cor pulmionale. In deze studie werd nifedipine toegediend zoals in het vorige hoofdstuk beschreven, terwijl captopril als intraveneuze bolus werd toegediend ( $2.5 \mathrm{mg}$ opgelost in 5 $\mathrm{mg}$ fysiologisch zout). Van orale toediening van captopril werd afgezien, omdat meetbare haemodynamische effecten hiervan pas na 1 à 2 uur zijn te verwachten. De intraveneuze toedieningsvorm van het nifedipine stond destijds niet ter onzer beschikking. Nifedipine en captopril werden alternerend toegediend bij 12 opeenvolgende patiënten.

\subsection{Uitgangswaarden}

De algemene gegevens van de 2 groepen tonen weinig verschillen, zoals samengevat in tabel 6.1. In beide groepen was de longfunctie ernstig gestoord, met een iets sterkere beperking van de $\mathrm{FEV}_{1}$ in de captoprilgroep.

De tendens tot een meer gestoorde gaswisseling in de laatste groep spreekt ook uit een wat lagere gemengd-weneuze zuurstofspanning. Het zuurstofverbruik lag in beide groepen gellik. Gezien het ruimere SOT in de nifedipinegroep, betekent dit dat de extractiecoëfficiënt $\left(\mathrm{VO}_{2} / \mathrm{SOT}\right)$ voor zuurstof hoger lag in de captoprilgroep.

De vergelijking van de haemodynamische variabelen in beide groepen toont enige verschillen (tabel 6.2). Bij gelijke waarden voor de vullingsdrukken, de RAP en de PCWP

Tabel 6.2: Uitgangswaarden woor de haenodyramiek bij 12 patienten met emstig obstructef longlijden, voorafgand aan nifedipine of captoprilinterventie.

\begin{tabular}{|c|c|c|c|c|}
\hline variabele & eenheid & $\begin{array}{l}\text { nifedipinegroep } \\
\qquad(\mathrm{n}=6)\end{array}$ & $\begin{array}{l}\text { captoprilgroep } \\
\qquad(\mathrm{n}=6)\end{array}$ & p \\
\hline MAP & $(\mathrm{mmHg})$ & $92 \pm 14$ & $98 \pm 14$ & NS \\
\hline$M P A P$ & $(\mathrm{mmHg})$ & $20 \pm 3$ & $24 \pm 6$ & NS \\
\hline $\mathrm{RAP}$ & $(\mathrm{mmHg})$ & $2 \pm 2$ & $2 \pm 2$ & NS \\
\hline PCWP & $(\mathrm{mm} H \mathrm{~g})$ & $6 \pm 2$ & $6 \pm 2$ & NS \\
\hline $\mathrm{CO}$ & $\left(1 . \mathrm{min}^{-1}\right)$ & $6.0 \pm 1.0$ & $4.9 \pm 0.45$ & NS \\
\hline SVR & $\left(\right.$ dyne $\left.\sec \mathrm{cm}^{-5}\right)$ & $1212 \pm 200$ & $1605 \pm 450$ & NS \\
\hline PVR & (dyne sec.cm $\left.\mathrm{cm}^{-5}\right)$ & $179 \pm 32$ & $302 \pm 87$ & $<0.01$ \\
\hline RPF & $\left(\mathrm{mllmin} \mathrm{m}^{-1}\right)$ & $344 \pm 13$ & $280 \pm 108$ & NS \\
\hline RBF & $\left(\mathrm{mllmin} \mathrm{m}^{-1}\right)$ & $711 \pm 99$ & $527 \pm 229$ & NS \\
\hline RVR & (dyne, sec $\mathrm{cm}^{-5}$ ) & $10823 \pm 3548$ & $17426 \pm 7187$ & $0.05<p<0.10$ \\
\hline
\end{tabular}


bleken de arterièle en pulmonale bloeddruk in de captoprilgroep niet significant hoger. De overig direct gemeten variabelen waren eveneens wergelijkbaar, waarbij opvalt dat het hartminuutvolume wat lager uitvalt, doch niet significant en binnen de norm, in de captoprilgroep. Tengevolge van dit verschil zijn de berekende variabelen zoals de pulmonale en renale vaatweerstand in de captoprilgroep hoger.

De gegevens met betrekking tot de activiteit van het sympatisch zenuwstelsel en het RAAS zijn samengevat in tabel 6.3. Ten aanzien van de absolute waarden wan de catecholaminen (noradrenaline, adrenaline en dopamine) valt op dat de gemengd-veneuze bepalingen iets hoger uitvallen dan de arteriële, terwijl de waarden voor A II, aldosteron en renine elkaar weinig ontlopen. De waarden van de catecholaminen in de captoprilgroep en de nifedipinegroep verschillen niet significant van elkaar, wel is er in de captoprilgroep een tendens tot iets hogere waarden (bijvoorbeeld de arteriële noradrenaline- en adrenalinespiegels, respectievelijk $3.05 \pm 1.59$ vs $2.53 \pm 1.26$ nmol. $^{-1}, p=N S$ en $0.44 \pm 0.34$ vs $0.33 \pm$ 0.15 n.mol. $\mathrm{l}^{-1}, \mathrm{p}=\mathrm{NS}$ ). De parameters van het RAAS verschillen evenmin significant van elkaar in de captopril- en nifedipinegroep. Bij het becordelen van de absolute waarden blijken echter de waarden van de reninebepalingen consistent te zijn verhoogd (arterieel 83 \pm 64 en $\left.99 \pm 83, \mathrm{n}<40 \mathrm{mE} . .^{-1}\right)$.

Tabel 6.3: Arteriele en gemengd-veneuze hormoonbepalingen bij 12 patienten melt ernstig obstructief longlijden, voorafgaand aan nifedipine- of captoprilloediening.

\begin{tabular}{lcccc}
\hline & \multicolumn{2}{c}{ nifedipinegroep $(\mathbf{n}=6)$} & \multicolumn{2}{c}{ captoprilgroep $(\mathbf{n}=6)$} \\
arterieel & gemengd-veneus & arterieel & gemengd-veneus \\
\hline noradrenaline & $2.53 \pm 1.26$ & $2.73 \pm 1.29$ & $3.05 \pm 1.59$ & $3.43 \pm 1.79$ \\
adrenaline & $0.33 \pm 0.15$ & $0.37 \pm 0.21$ & $0.44 \pm 0.34$ & $0.55 \pm 0.44$ \\
dopamine & $0.50 \pm 0.31$ & $0.53 \pm 0.22$ & $0.33 \pm 0.11$ & $0.45 \pm 0.20$ \\
angiotensine II & $16.6 \pm 9.8$ & $12.2 \pm 6.8$ & $22.1 \pm 21$ & $19 \pm 18$ \\
aldosterone & $461 \pm 211$ & $501 \pm 272$ & $367 \pm 199$ & $341 \pm 164$ \\
renine & $83 \pm 64$ & $78 \pm 55$ & $99 \pm 83$ & $92 \pm 73$ \\
ANP & $121 \pm 84$ & $117 \pm 89$ & $122 \pm 41$ & $99 \pm 41$ \\
\hline
\end{tabular}




\subsection{Effecten van nifedipine en captopril}

\subsubsection{Haemodynamiek}

Onder invloed van beide medicamenten trad een daling op in de bloeddruk en de vaatweerstand. Deze veranderingen zijn weergegeven in figuur 6.1. De wijzigingen in de bloeddruk toonden een soortgelijk beloop. Onder inwloed van nifedipine daalde de MAP met 10 en 13\% ( $v a n 92 \pm 14$ naar $82 \pm 12$ en $80 \pm 14 \mathrm{mmHg}$ ), terwijl captopril de bloeddruk verlaagde met $8 \%$ en $6 \%$ na 15 en 60 minuten (van $98 \pm 12$ naar $91 \pm 12$ en $93 \pm 12$ mmHg). De hartminuutvolume-index onder unvloed van nifedipine steeg met $16 \%$ en $7 \%$ na 15 en 60 minuten, terwijl de veranderingen ten gevolge van captopril nauwelijks opvielen (stijging van $\mathrm{Cl}$ met $6 \%$ en $2 \%$ na 15 en 60 minuten). De procentuele veranderingen in beide groepen waren verschillend (figuur 6.1).

In de nifedipinegroep daalde de SVR met $23 \%$ na 15 minuten en met $16 \%$ na 60 minuten (van $1212 \pm 200$ naar $925 \pm 163$ en naar $995 \pm 118$ dyne.sec.cm $^{-5}, \mathrm{p}=0.06$ ). De veranderingen in de captoprilgroep waren minder uitgesproken: de SVR daalde met $14 \%$ na 15 minuten en met $4 \%$ na 60 minuten (van $1605 \pm 450$ naar $1380 \pm 201$ en naar $1540 \pm 290$ dyne.sec. $\mathrm{cm}^{-5}, \mathrm{p}=\mathrm{NS}$ ). Wanneer de curves tegen elkaar worden uitgezet, blijkt het beloop in beide groepen significant van elkaar te verschillen, waarbij uiteraard de vraag resteert of deze waarneming volgt uit de gekozen dosering en toedieningsvorm.

Met betrekking tot de vullingsdrukken traden geen veranderingen op, hoewel in de captoprilgroep een trend tot dalen van de PCWP was te zien (van $6 \pm 2$ naar $5 \pm 2$ en naar $4 \pm 2 \mathrm{mmHg}$ na 15 en 60 minuten). De RAP vertoonde in de 2 groepen een geringe, nietsignificante daling. Het beloop van de mPAP verschilde in beide groepen. Onder invloed van nifedipine trad initieel een lichte stijging op (van $20 \pm 3$ naar $22 \pm 5$ en terug naar 20 $\pm 3 \mathrm{mmHg}$ na 15 en 60 minuten. In de captoprilgroep daalde de mPAP licht, van $24 \pm 6$ naar $22 \pm 4$ en $23 \pm 4 \mathrm{mmHg}$ na 15 en 60 minuten. Ten opzichte van de uitgangswaarden waren de veranderingen niet significant, doch wanneer de beide groepen met elkaar worden vergeleken, zijn de trends wel significant verschillend (figuur 6.2). Met betrekking tot de PVR werden geen significante veranderingen vastgesteld.

De waarden van de variabelen met betrekking tot de nierdoorbloeding, de RPF en RBF, namen toe onder invloed van nifedipine en captopril, zonder dat significante veranderingen werden vastgesteld. In de nifedipine-groep steeg de RPF met $9 \%$ en $18 \%$ na 15 en 60 
Figuur 6.1: Nifedipine vs captopril: Haemodynamische effecten,
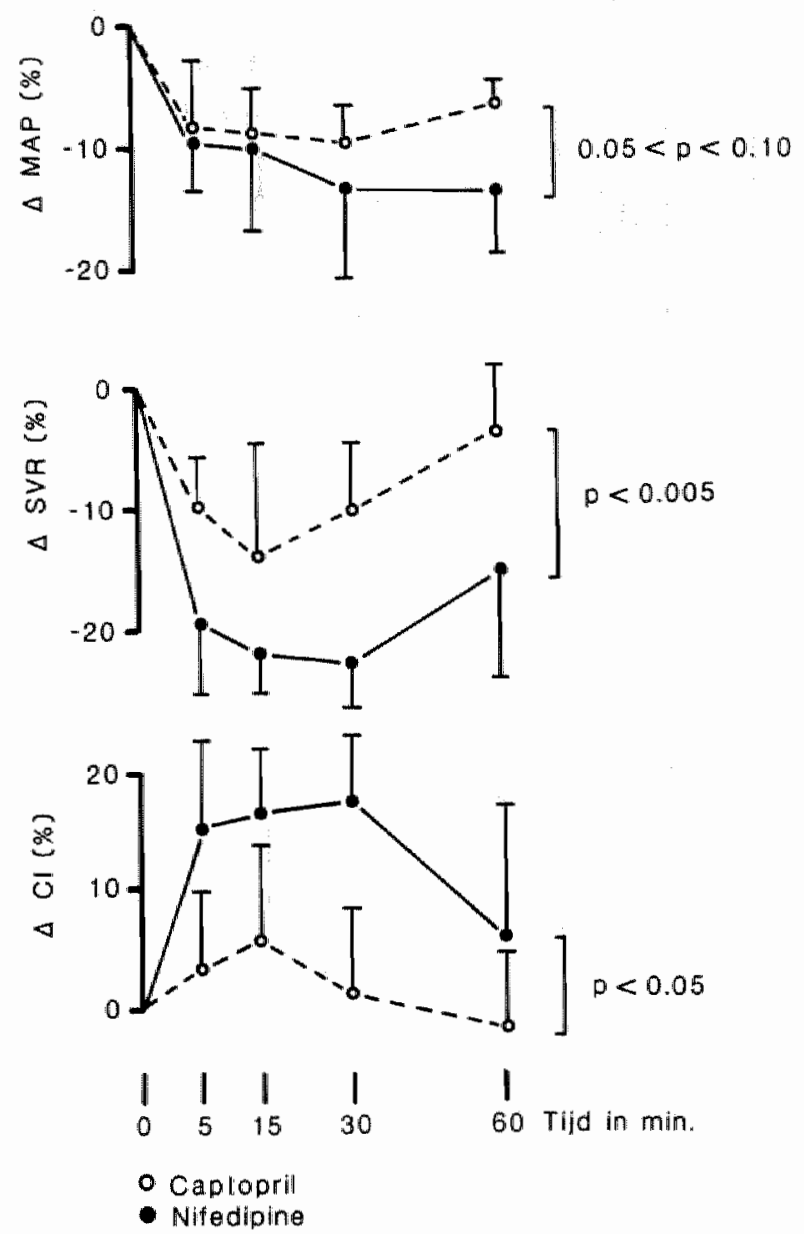

minuten ( naar $372 \pm 11$ en $408 \pm 37 \mathrm{ml} \cdot \mathrm{min}^{-1}, \mathrm{p}=\mathrm{NS}$ ), terwijl in de captoprilgroep de toename $20 \%$ en $18 \%$ bedroeg na 15 en 60 minuten (naar $341 \pm 50$ en $333 \pm 48 \mathrm{ml} . \mathrm{min}^{\circ}$, $\mathrm{p}=\mathrm{NS})$.

\subsubsection{Gaswisseling}

Hoewel de veranderingen in $\mathrm{PaO}_{2}$ en shuntfractie onder invloed van nifedipine en captopril niet erg groot waren, bleken in beide groepen de procentuele veranderingen toch significant 
Fugur 6,2: Nifedipitre vs captopril, Invloeden op de mPAP en gaswisseling.
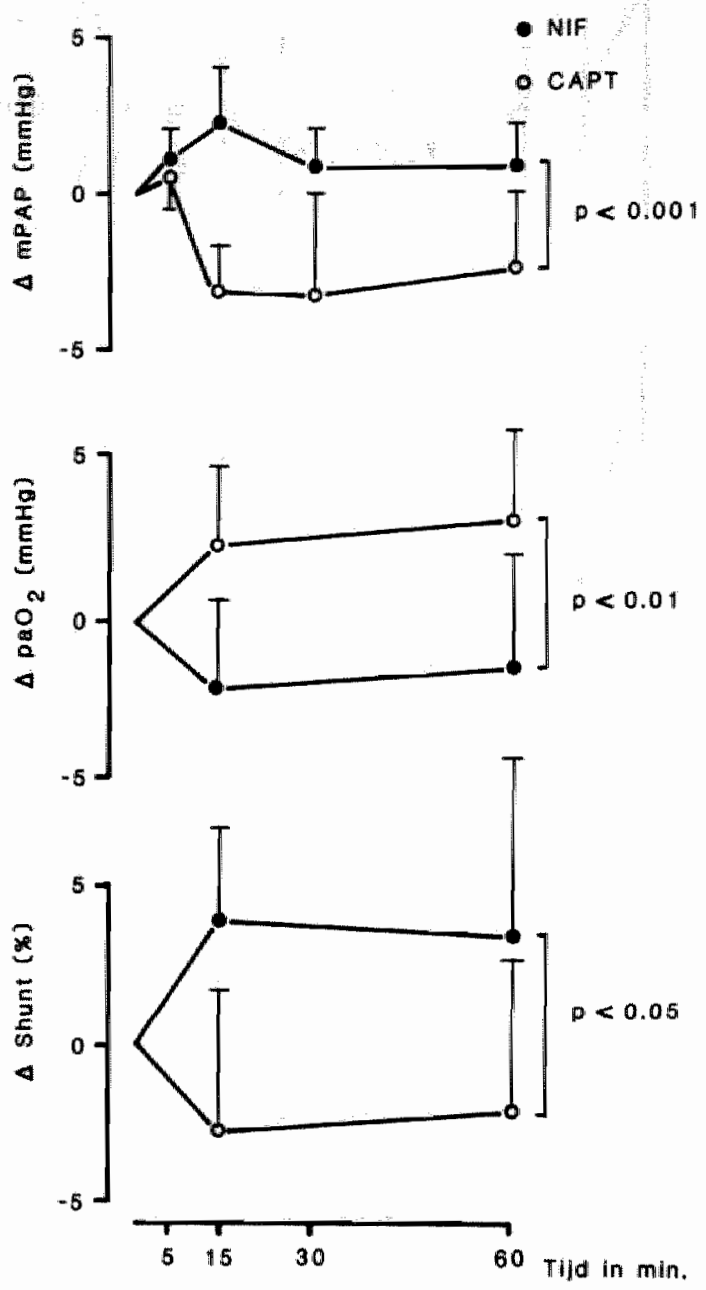

van elkaar te verschillen (figuur 6.2)

Nifedipine veroorzaakte een toename in de shuntfractie, van $19 \pm 10$ naar $23 \pm 8$ na 15 en naar $23 \pm 9$ na 60 minuten, terwijl in de captoprilgroep de shunt juist daalde, van $17 \pm 7$ naar $14 \pm 6$ na 15 minuten en naar $15 \pm 8$ na 60 minuten. De veranderingen in de $\mathrm{PaO}_{2}$ waren vergelijkbaar. In absolute zin steeg de $\mathrm{PaO}_{2}$ met $2 \pm 3 \mathrm{mmHg}$ na 15 minuten en met $3 \pm 3 \mathrm{mmHg}$ in de captoprilgroep en daalde met $2 \pm 3 \mathrm{mmHg}$ na 15 minuten en met $2 \pm$ 
$4 \mathrm{mmHg}$ na 60 minuten na nifedipinetoediening. Het arterièle en gemengd-veneuze $\mathrm{CO}_{2}$ gehalte bleef in beide groepen ongewijzigd.

Als gevolg van de verandering in hartminuutvolume en $\mathrm{PaO}_{2}$ traden ook schommelingen op in de SOT. In de nifedipinegroep steeg de SOT met $15 \pm 9$ en $7 \pm 16 \%$ na 15 en 60 minuten ( $\mathrm{p}<0.05$ t.o.v. de uitgangswaarden), terwijl de SOT in de captoprilgroep nauwelijks veranderde, met $8 \pm 12$ na 15 en $-1 \pm 8 \%$ na 60 minuten ( $p=$ NS).

De veranderingen in het gebruik van zuurstof $\left(\mathrm{VO}_{2}\right)$ waren onopvallend. De procentuele veranderingen in de 2 groepen waren niet significant van elkaar verschillend.

\subsubsection{Hormoonwaarden}

De invloeden van nifedipine en captopril op het sympatische zenuwstelsel en het RAAS zijn weergegeven in de figuren 6.3 en 6.4. Onder invloed van beide middelen stegen de serumspiegels van noradrenaline, adrenaline en dopamine, zowel arterieel als gemengdveneus. De veranderingen waren het meest uitgesproken woor het arteriële dopamine-gehalte, onder invloed van captopril. Het arteriële dopamine steeg met $23 \%$ en $53 \%$ na 15 en 60 minuten (naar $0.43 \pm 0.16$ en $0.50 \pm 0.16$ nmol. $^{-1}, \mathrm{p}<0.05$ ). Het gemengd-veneuze noradrenaline steeg met $30 \%$ en $49 \%$ na 15 en 60 minuten (naar $4.35 \pm 2.40$ en $4.35 \pm 1.38$ nmol. $.^{1}, 0.05<p<0.10$ ). De veranderingen in de nifedipine-groep waren niet significant van aard.

Met betrekking tot het RAAS, was duidelijk dat aldosteron en angiotensine II werden geremd door captopril, terwijl het renine steeg. Hoewel de veranderingen in absolute zin niet significant van aard waren (figur 6.4), waren de procentuele veranderingen na captopriltoediening zeer significant, zowel arterieel als gemengd-veneus. Zo nam bijvoorbeeld het arteriële A II af met $50 \%$ en $43 \%$ na 15 en 60 minuten $(p<0.001)$, terwijl het aldosteron daalde met $40 \%$ en $35 \%$ na 15 en 60 minuten $(p<0.05)$. De veranderingen in het renine-gehalte waren slechts van significante aard voor de gemengd-veneuze waarden $(0.05<\mathrm{p}<0.10)$. Nifedipine daarentegen veroorzaakte geringe stijgingen van de 3 betreffende hormonen. Voor beide stoffen geldt, zoals blijkt uit de figuren, dat het beloop van de gemengd-veneuze en arteriële bepalingen gelijk is.

Ten aanzien van het ANP werd het beloop verschillend beinvloed door toediening van nifedipine en captopril. Onder invloed van nifedipine trad er geen verandering op in het anteriële ANP-gehalte, doch wel in de gemengd-weneuze waarden (naar $86 \pm 77$ en $95 \pm 77$ pg.ml $\mathrm{m}^{-1}$, oftewel een daling van $30 \%$ en $20 \%$ na 15 en 60 minuten, $\mathrm{p}<0.001$ ). Daarentegen 
Figuur 6.3: Catecholaninespiegels onder invloed van nifedipine (en caplopritl.
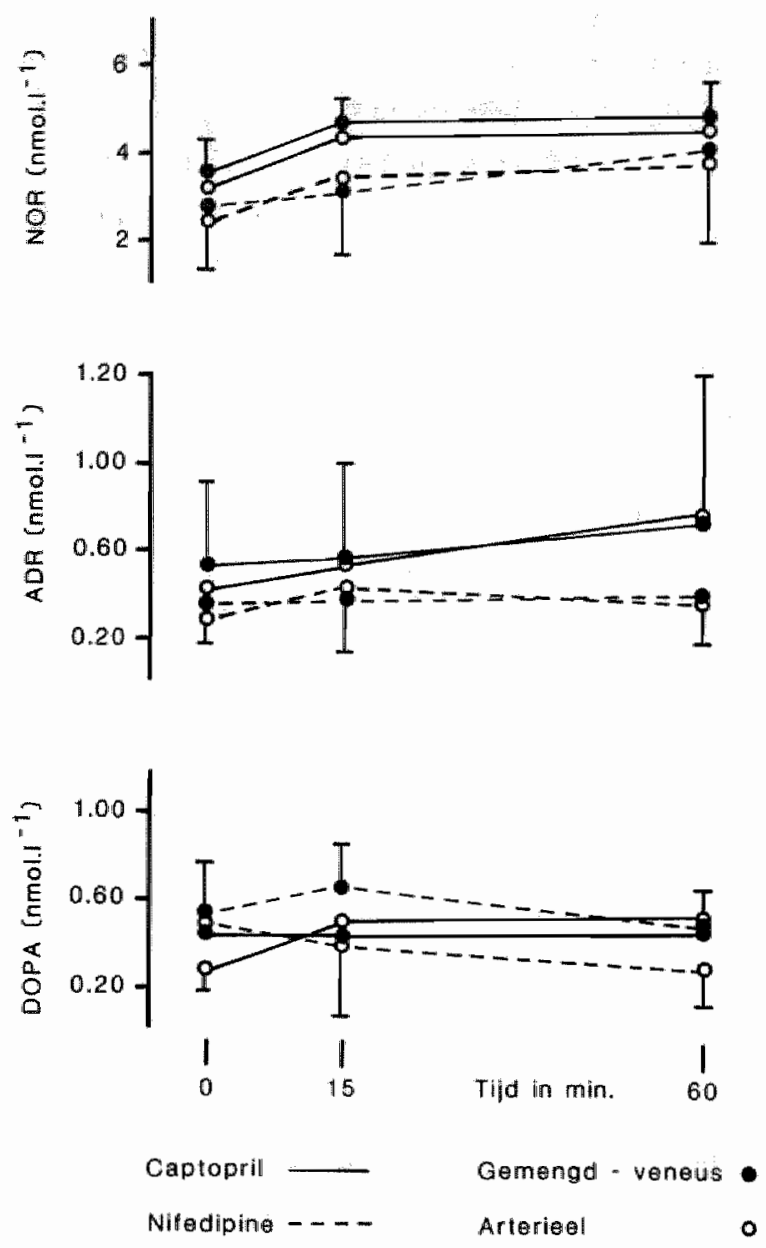

werd na captopriltoediening geen verandering vastgesteld in de gemengd-veneuze waarden, doch wel in de arterieel bepaalde waarden (naar $103 \pm 28$ en $100 \pm 30 \mathrm{pg}^{-\mathrm{ml}^{-1}}$ na 15 en 60 minuten, hetgeen overeenkomt met een daling van $15 \%$ en $19 \%, \mathrm{p}<0.05$ ). 
Figuur 6.4: Hormoonspiegels onder invloed van nifedipine en captopril.
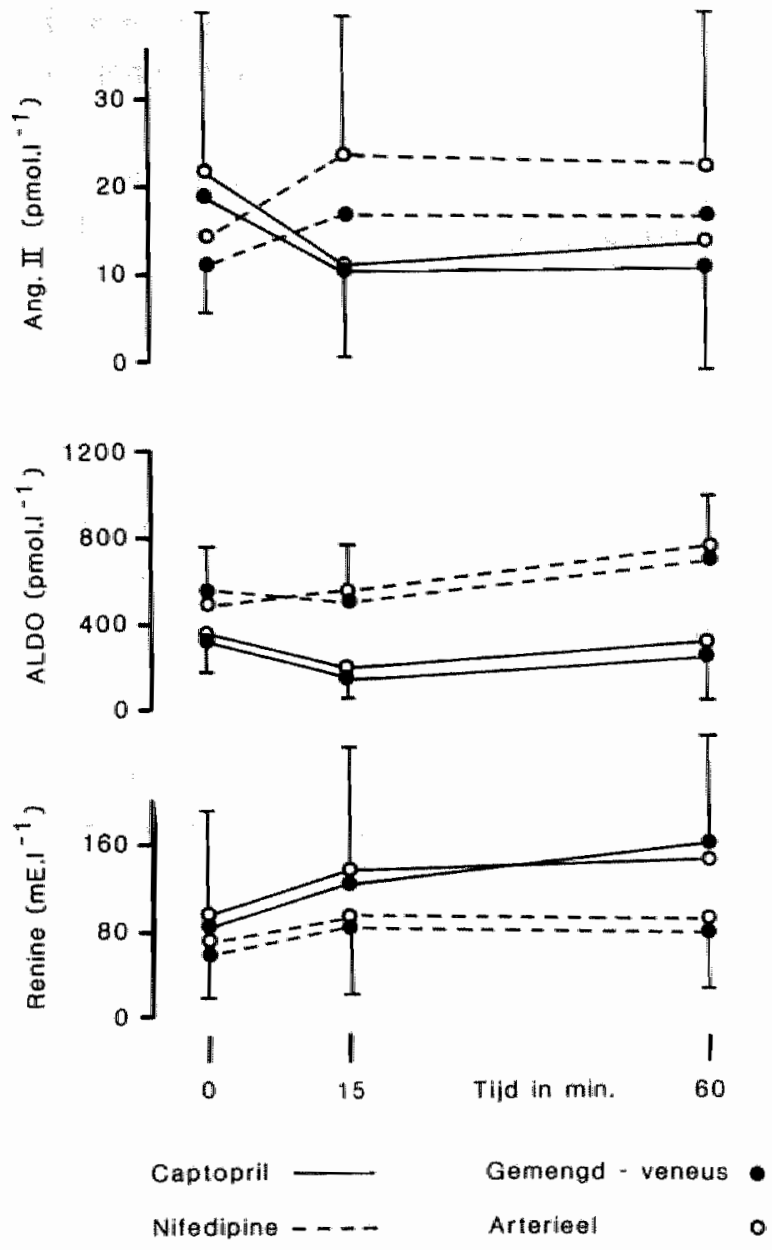

\subsection{Bespreking}

Alvorens de gegevens diepgaander te bespreken, dient men in aanmerking te nemen dat de groepen van kleine omvang waren en ails zodanig slechts trendmatige conclusies toestaan. Nifedipine gedraagt zich conform de resultaten uit hoofdstuk 5 als een arteriele vaatverwijder. De toename in hartminuutvolume gat gepaard met een licht stijgende of gelijkblijvende mPAP waardoor de afterload van de rechter ventrikel slechts gerimg 
verandert. Deze waarnemingen, toename van hartminuutvolume en daling van de pulmonale vaatweerstand, zouden de daling van het gemengd-veneuze ANP kunnen verklaren, er vanuit gaande dat ANP inderdaad als een pulmonale vasodilatator werkt door middel van een feedback-mechanisme met het rechter atrium [Westendorp et al 1990]. Captopril daarentegen, veroorzaakt een afname van het arteriêle ANP, zonder wijziging in de gemengd-veneuze waarde. Gezien de meer uitgesproken systemische bloeddrukdaling door nifedipine, lijkt de afname van het ANP in de captoprilgroep niet bloeddrukafhankelijk.

De door ons gevonden effecten van captopril wijken af van die in de literatuur hetgeen waarschijnlijk berust op de normoxie en de lage intraveneuze dosering. Bij hypoxische patiënten veroorzaakt captopril per os, 25 of $50 \mathrm{mg}$, een duidelijke bloeddrukdaling samen met verlaging van de wiggedruk en de mPAP [Bertoli et al 1986, Zielinsky et al 1986]. Captopril toegevoegd aan LTOT veroorzaakte dezelfde effecten, dus daling van MAP, mPAP en RAP [Burke et al 1985]. Daarentegen er zijn ook studies beschreven waarin captopril de MAP en de coronaire bloedstroom naar de rechter ventrikel verlaagt zonder dat wijzigingen in de MPAP optreden [Patakas et al 1988].

In onze studie veroorzaakte captopril minimale veranderingen in systemische bloeddruk en vaatweerstand, terwijl de vullingsdrukken en de mPAP licht afnamen, het geheel had een lichte verbetering van de gaswisseling tot gevolg. De nifedipinegroep daarentegen toont de verwachte arteriële vaatverwijding met secundaire gevolgen voor hartminuutvolume, shunt en $\mathrm{PaO}_{2}$.

De lichte verbetering van gaswaarden en shunt na captopril is niet volledig verklaard. In eerdere studies werd geen verandering in de ventilatie perfusie verhouding in de long vastgesteld na captopriltoediening [Borkenstein ot al 1987], terwijl toename van de veneuze shuntfractie door nifedipine is beschreven [Melot et al 1984]. Sommige auteurs hebben gesuggereerd dat door ernstige pulmonale hypertensie de valwand ongevoelig wordt voor vasodilatatoren [Ringsted et al 1989]. Bij de door ons beschreven groepen lijkt de mPAP daar niet hoog genoeg voor (mPAP 20 en $24 \mathrm{mmHg}$ in de nifedipine- en captoprilgroep).

In vroegere onderzoekingen met captopril zijn wisselende resultaten gemeld met betrekking tot de invloed op de $\mathrm{PaO}_{2}$. Indien het hartminuutvolume onder captopril daalt, wordt een daling van de $\mathrm{PaO}_{2}$ en mPAP gevonden [Borkenstein et al 1987]. Wanneer het hartminuutvolume stijgt, verbetert captopril ook de gemengd-veneuze saturatie en het zuurstoftransport [Burke et al 1985]. De geringe systemische invloed en de lage dosis captopril in de huidige studie doen de vraag rijzen of deze vorm, additief aan OZT, kan dienen als alternatief voor de toediening van ACE-remmers in doseringen zoals bij hypertensie of linker-ventrikelfalen. 
De belangstelling voor het lokale, weefselgebonden RAAS sluit hierbij aan [Frohlich 1989]. Gezien de intraveneuze toediening van captopril en het feit dat bij orale toediening het middel eerst de portale circulatie passeert, lijkt er wel een indicatie tot verder onderzoek. Dit zou zowel de hogere doseringen ACE-remmer als de langer werkende vorm kunnen betreffen. 


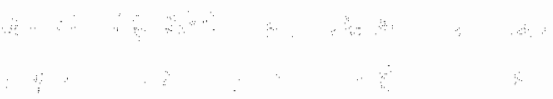




\section{De overleving van de patiënten}

\subsection{Inleiding}

De patiënten, welke onderzocht werden in de periode van 1986 tot en met 1990, werden wervolgd in de tijd om na te gaan of de door ons gevonden afwijkingen voorspellende waarde hadden ten aanzien van de mortaliteit in deze groep. In de analyse werden 49 patiënten betrokken.

De patiënten werden poliklinisch vervolgd door de behandelend longarts of internist. Voor ontslag werd door de longarts beslist over de toediening van zuurstof OZT. Uiteindelijk betrof dit 40 patiënten uit de groep van 49 .

Indien tot de toediening van zuurstof werd besloten, geschiedde dit op de gebruikelijke wijze, te weten in overleg met de patiënt, huisarts, maatschappelijk werk en de installateur (Fa. Hoekloos).

De voorgeschreven duur van de toediening bedroeg tenminste 16 uur per dag. Alle patiënten, ook degenen zonder pulmonale hypertensie of hypoxie, werden regelmatig op de polikliniek gezien, waar tevens bloedgascontrole plaats vond.

Als meetpunten voor de overleving werden genomen de datum van onderzoek en de datum van overlijden of laatste controle. Deze data werden verkregen uit de klinische en poliklinische verslagleggingen. Bij onduidelijkheid over de status (in leven/overleden) werd contact opgenomen met de huisarts of de afdeling bevolking van de gemeente Rotterdam. De doodsoorzaak van de overleden patiënten werd op dezelfde wijze verkregen.

De overlevingscurves werden berekend met behulp van de Kaplan-Meier-methode. De logrank-test werd gebruikt om significante verschillen met betrekking tot de overleving vast te stellen tussen groepen. De Cox-regressieanalyse werd verricht om de invloed op de overleving van de diverse fysiologische variabelen uit het haemodynamische onderzoek te bepalen. 


\subsection{Resultaten}

De overleving van de gehele groep $(n=49)$ is weergegeven in figuur 7.1. De overleving volgens Kaplan-Meier toont na 2 jaar een overleving van ongeveer $60 \%$ en na 4 jaar van ongeveer $40 \%$. Tijdens de follow-up-periode, die voor sommige nog in leven zijnde patiënten inmiddels 5 jaar bedraagt, overleden 23 patiënten. De mediane overleving van deze patiënten bedroeg 13 maanden; de oorzaken van overlijden staan vermeld in tabel 7.1. Vier patiënten overleden aan maligniteiten na respectievelijk $3,7,14$ en 15 maanden follow-up. Vijf patiënten overleden reeds na respectievelijk 1,2 en 3 maanden ten gevolge van respiratoire insufficiëntie; drie van hen waren bekend met chronisch cor pulmonale en werden reeds eerder mechanisch beademd. Indien alleen die patiënten worden beschouwd, die voór 1988 werden onderzocht, blijkt er bij het vergelijken van degenen die zijn overleden met degenen die in leven zijn gebleven, nauwelijks verschil te bestaan voor wat betreft de tijdens het eerste onderzoek gevonden waarden voor haemodynamiek en gaswaarden, met uitzondering van de $\mathrm{PvO}_{2}$ en $\mathrm{SvO}_{2}$ (tabel 7.2).

Figuur 7.1: Overlevingscurwe bij 49 patiènten.

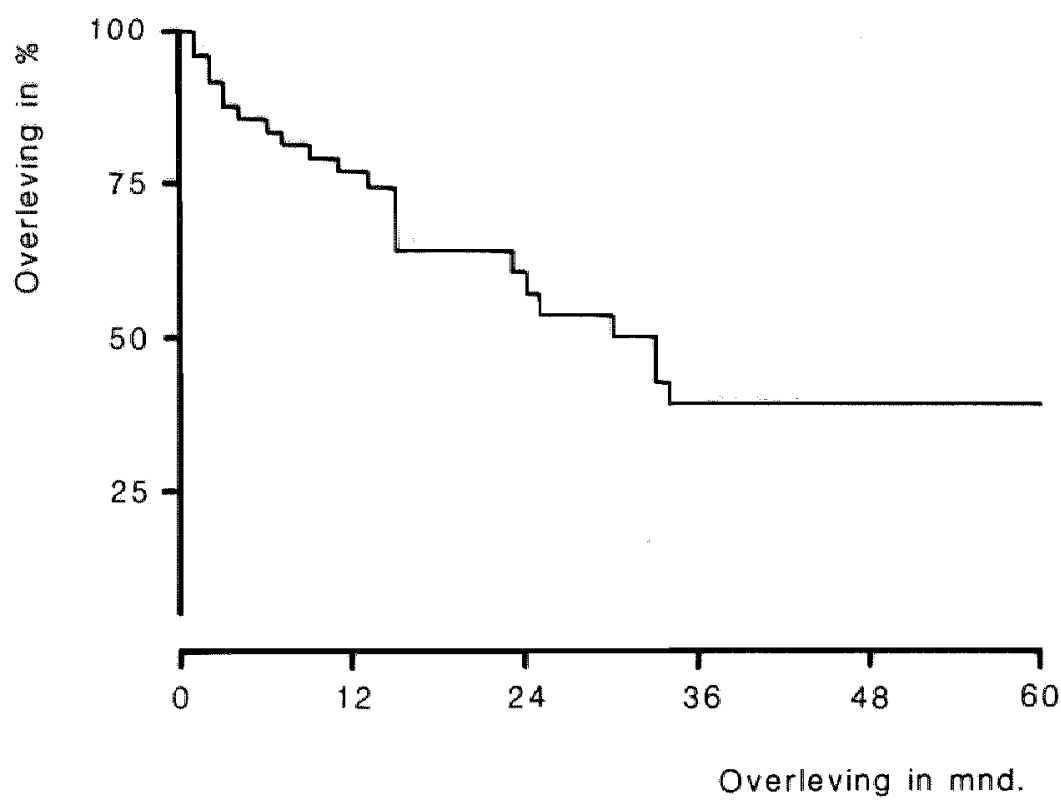


Tabel 7.1: Oorzaken van overlijden bij 23 patienten tijdens de follow-up.

\begin{tabular}{lc}
\hline oorzaken van overlijden & aantal patiènten \\
\hline $\begin{array}{l}\text { respiratioire insuffici- } \\
\text { entie }\end{array}$ & 17 \\
- maligniteit & \\
bronchuscarcinoom & \\
oesophaguscarcinoom & 3 \\
- cardiovasculair & 1 \\
- onbekend & 1 \\
& 1 \\
\hline
\end{tabular}

Tabel 7.2: Samenvatting van de belangrijkste basale , algemene en haemodynamische variabelen bij 31 patienten, na tenminste 3 jaar follow-up.

\begin{tabular}{|c|c|c|c|c|}
\hline $\begin{array}{l}\text { variabele bij het } \\
\text { eerste onderzoek }\end{array}$ & eenheid & $\begin{array}{c}\text { overleden } \\
(\mathrm{n}=14)\end{array}$ & $\begin{array}{l}\text { in leven } \\
(\mathrm{n}=17)\end{array}$ & p" \\
\hline leeftijd & (Jaren) & $69 \pm 8$ & 68 tw 9 & NS \\
\hline BSA & $\left(m^{2}\right)$ & $1.70 \pm 0.15$ & $1.77 \pm 0.18$ & $\mathrm{NS}$ \\
\hline $\mathrm{Hb}$ & $\left(\mathrm{mmol} \mathbb{1}^{-1}\right)$ & $9.9 \pm 1.0$ & $10.2 \pm 1.0$ & NS \\
\hline $\mathrm{FEV}_{1}$ & (B) & $0.85 \pm 0.23$ & $0.80 \pm 0.20$ & NS \\
\hline $\mathrm{HF}$ & (slagen.min ${ }^{-1}$ ) & $90 \pm 14$ & $87 \pm 13$ & $\mathrm{NS}$ \\
\hline MAP & $(\mathrm{mmH} g)$ & $89 \pm 14$ & $95 \pm 12$ & $\mathrm{NS}$ \\
\hline RAP & $(\mathrm{mmHg})$ & $2 \pm 2$ & $3 \pm 3$ & NS \\
\hline mPAP & $(\mathrm{mmHg})$ & $21 \pm 8$ & $23 \pm 9$ & NS \\
\hline PCWP & $(\mathrm{mmHg})$ & $6 \pm 3$ & $7 \pm 3$ & NS \\
\hline $\mathrm{Cl}$ & $\left(1 \cdot \mathrm{min}^{-1} \cdot \mathrm{m}^{-3}\right)$ & $3.02 \pm 0.84$ & $3.26 \pm 0.64$ & NS \\
\hline SVR & $\left(\right.$ dyne.sec. $\left.\mathrm{cm}^{-5}\right)$ & $1456 \pm 399$ & $1351 \pm 318$ & $\mathbb{N S}$ \\
\hline PVR & (dyne.sec. $\mathrm{cm}^{-5}$ ) & $252 \pm 128$ & $225 \pm 114$ & NS \\
\hline $\mathrm{FiO}_{2}$ & $(\%)$ & $24 \pm 3$ & $24 \pm 3$ & $\mathbb{N S}$ \\
\hline $\mathrm{PaO}_{2}$ & $(\mathrm{mmHg})$ & $71 \pm 14$ & $72 \pm 18$ & NS \\
\hline $\mathrm{PvO}_{2}$ & $(\mathrm{mmHg})$ & $36 \pm 4$ & $40 \pm 4$ & $p<0.05$ \\
\hline $\mathrm{SvO}_{2}$ & $(\%)$ & $68 \pm 4$ & $73 \pm 5$ & $p<0.05$ \\
\hline $\mathrm{PaCO}_{2}$ & $(\mathrm{mmHg})$ & $44 \pm 7$ & $48 \pm 7$ & NS \\
\hline SOT & $\left(\mathrm{mll} \mathrm{min}^{-5}\right)$ & $1046 \pm 361$ & $1219 \pm 311$ & $\mathrm{NS}$ \\
\hline $\mathrm{VO}_{2}$ & $\left(\mathrm{ml} \min ^{-1}\right)$ & $284 \pm 85$ & $271 \pm 74$ & NS \\
\hline $\mathrm{VO}_{2} / \mathrm{SOT}$ & & $0.27 \pm 0.05$ & $0.22 \pm 0.06$ & $p<0.05$ \\
\hline
\end{tabular}


Tabel 7.3: Univariate regressicanalyse volgens de Cox-methode met betrokking tot de overllewing.

\begin{tabular}{|c|c|c|c|}
\hline variabele & eenheid & p & $x^{2}$ \\
\hline leefuid & (jaren) & 0.10 & \\
\hline $\mathrm{BSA}$ & $\left(m^{2}\right)$ & 0.66 & \\
\hline $\mathrm{Hb}$ & $\left(\right.$ mmol. $\left.1^{-1}\right)$ & 0.21 & \\
\hline $\mathrm{FEV}_{1}$ & (1) & 0.30 & \\
\hline $\mathrm{FEV}_{1} / \mathrm{FVC}$ & $\left(1.1^{12}\right)$ & 0.49 & \\
\hline $\mathrm{FiO}_{2}$ & & 0.88 & \\
\hline $\mathrm{PaO}_{2}$ & $(\mathrm{mmHg})$ & 0.50 & \\
\hline $\mathrm{PvO}_{2}$ & $(\mathrm{mmHg})$ & $<0,05 *$ & 5.62 \\
\hline $\mathrm{SaO}_{2}$ & & 0.68 & \\
\hline $\mathrm{SvO}_{2}$ & & $<0.001 *$ & 6.94 \\
\hline $\mathrm{PaCO}_{2}$ & $(\mathrm{mmHg})$ & 0.94 & \\
\hline shunt & & 0.70 & \\
\hline SOT & $\left(\mathrm{ml} \cdot \mathrm{min}^{-1}\right)$ & 0.17 & \\
\hline $\mathrm{VO}_{2}$ & $\left(\mathrm{ml} \cdot \mathrm{min}^{-1}\right)$ & 0.29 & \\
\hline $\mathrm{VO}_{2} / \mathrm{SOT}$ & & $<0.01 *$ & -7.55 \\
\hline MAP & $(\mathrm{mmHg})$ & $0.05<p<0.10^{*}$ & 2.75 \\
\hline mPAP & $(\mathrm{mmHg})$ & 0.44 & \\
\hline RAP & $(\mathrm{mmHg})$ & 0.39 & \\
\hline PCWP & $(\mathrm{mmHg})$ & 0.23 & \\
\hline $\mathrm{HF}$ & $\left(\right.$ slagen $\left.\min ^{-1}\right)$ & $<0.05^{*}$ & -4.09 \\
\hline $\mathrm{Cl}$ & $\left(1 . \mathrm{min}^{-1} \cdot \mathrm{m}^{-2}\right)$ & 0.41 & \\
\hline SVI & $\left(\mathrm{ml} . \mathrm{slag}^{-1}, \mathrm{~m}^{-2}\right)$ & 0.10 & \\
\hline SVR & (dyne.sec.cm ${ }^{-5}$ ) & 0.28 & \\
\hline PVR & $\left(\right.$ dyne,sec.cm $\left.{ }^{-5}\right)$ & 0.92 & \\
\hline LVSWI & $\left(\mathrm{g} \cdot \mathrm{m}^{-2}\right)$ & $<0.05 *$ & 5.24 \\
\hline RVSWI & $\left(\mathrm{g} \cdot \mathrm{m}^{2}\right)$ & $0.05<p<0.10^{*}$ & 3.25 \\
\hline
\end{tabular}

In de univariate bewerking met de Cox-regressiemethode werden de diverse variabelen beoordeeld naar hun yoorspellende waarde ten aanzien van de overleving in de gehele groep. De resultaten van deze analyse zijn weergegeven in tabel 7.3. De uitgangswaarden voor de leeftijd en lichaamsoppervlak en de waarden van de hemoglobinegehalten en de hematocriet bleken niet gerelateerd aan de overleving, evenmin als de longfunctieparameters. 
De arteriële gaswaarden bleken ook geen prognostische waarde te hebben in de huidige studie. Noch de ernst van de hypercapnie noch de mate van hypoxie hadden een duidelijke invloed op de overleving.

Daarentegen bleken de gemengd-veneuze zuurstofsaturatie en -spanning wel van prognostische waarde. Dit gold eveneens voor de extractieratio voor zuurstof (verbruik gedeeld door transport).

Binnen de rij van haemodynamische variabelen bleek de pulmonale haemodynamiek (mPAP, PVR, Cl) geen voorspellende waarde te hebben ten aanzien van de overleving. Opvallend genoeg is er wel enige invloed van de arteriële bloeddruk, waarbij een hogere bloeddruk een betere prognose inhoudt bij deze categorie patiënten. Indien de arbeid van het hart weergegeven wordt als LVSWI en RVSWI, dan hebben deze afgeleide parameters prognostische betekenis, evenals de hartfrequentie in rust. De absolute waarden van de vullingsdrukken (wiggedruk en RAP) speelden geen rol van betekenis.

Figuur 7.2: Arteriële A II-spiegels in relatie tot overleving.

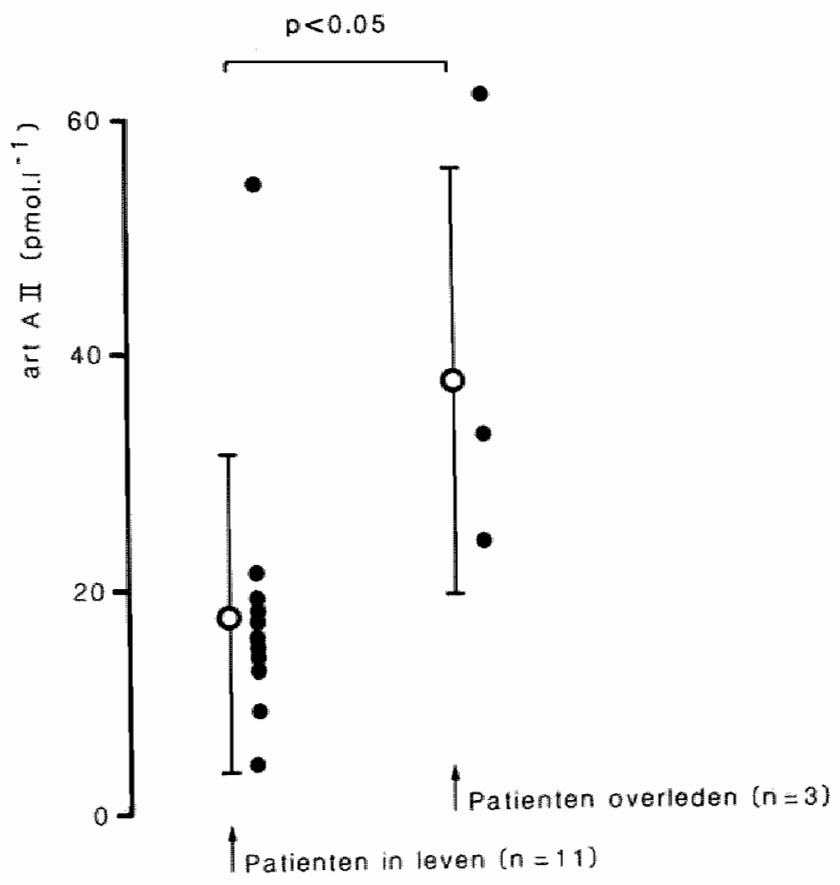


Figur 7 : Inwloed van de harffrequentie op de overlewing.

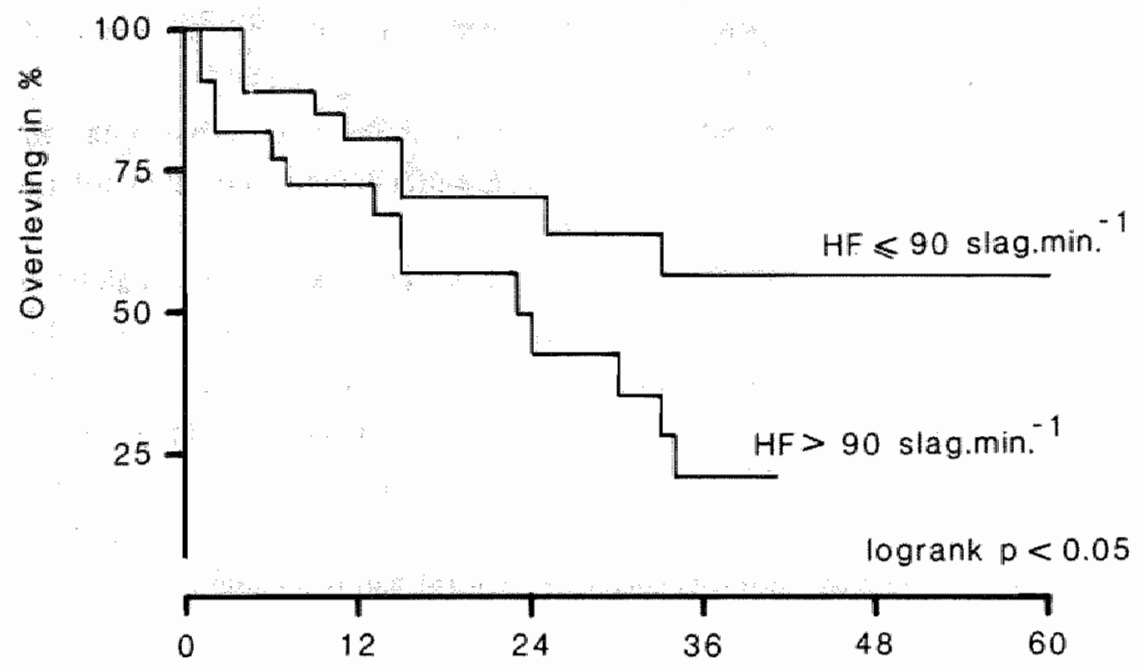

Overleving in mnd.

Figuur 7.4: Invloed van het zuursioftransport op de overleving.

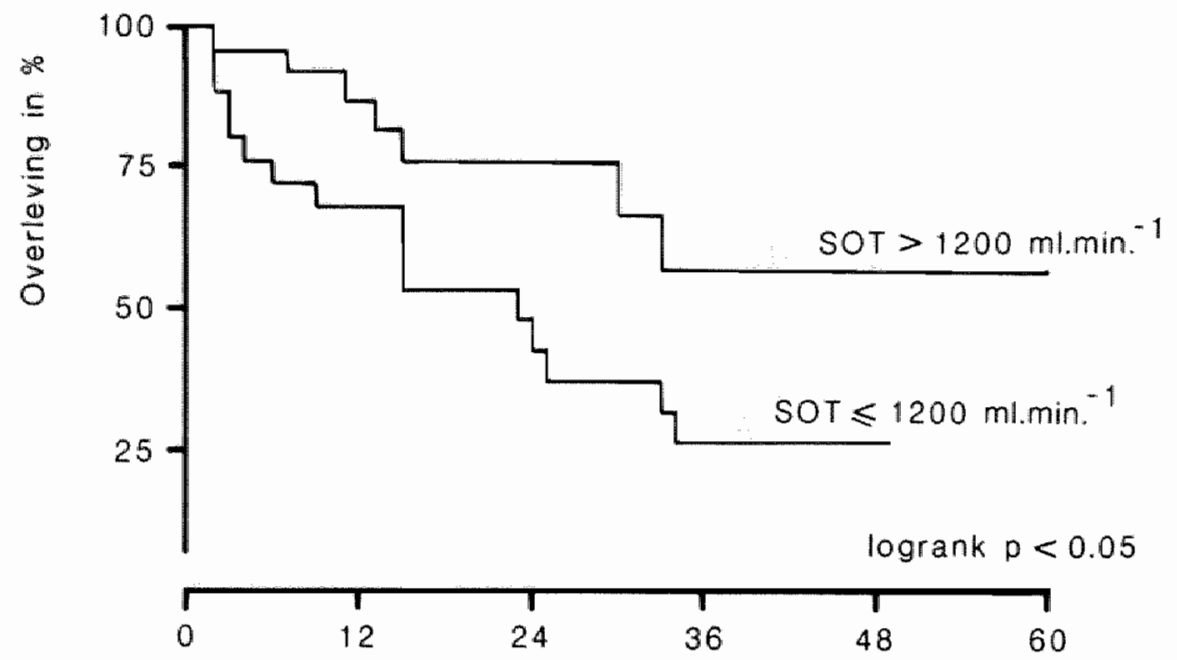

Overleving in mnd. 
Indien bij de beschrijving van de prognostische factoren, een indruk van de neuroendocriene status weergegeven wordt, valt als belangrijke factor de hoogte van het arterielle angiotensine II op (Cox-regressie; $p=0.02 ; \chi^{2}=5.33$ ). Uiteraard dient de beperkte observatieduur in de subgroep (mediaan 14 maanden, range 6 - 42 maanden) en het geringe aantal patiënten in acht genomen te worden, doch opvallend is de bevinding wel (figuur 7.2).

Naar aanleiding van de univariate regressie-anallyse werd voor een aantal variabelen subgroepanalyse toegepast. Daarbij treedt de prognostische waarde van het zuurstoftransport en de hartfrequentie op de voorgrond. In onze studie hebben de patiënten met een hartfrequentie lager dan 90 slagen per minuut of een zuurstoftransport groter dan 1200 mll.min ${ }^{-1}$ een gunstiger prognose (figuren 7.3 en 7.4 ).

\subsection{Bespreking}

Zoals eerder weergegeven in hoofdstuk 2 , zijn er verschillende inzichten met betrekking tot de lange-termijn-overleving van patiënten met chronisch obstructief longlijden.

In een Japanse studie bij patiënten zonder OZT, bleken de $\mathrm{PaO}_{2}$ en $\mathrm{PvO}_{2}$ de factoren die significant verschilden in de groepen overlevende versus niet-overlevende patiënten [Kawakami et al 1983]. In deze studie hadden de mPAP, PVR en CI geen voorspellende waarde. Het belang van de gaswaarden is later bevestigd door de groep van MacNee. In een studie met

Figuur 7.5: Overleving wan de eigen paticnten in vergelijking tot andere sudies.

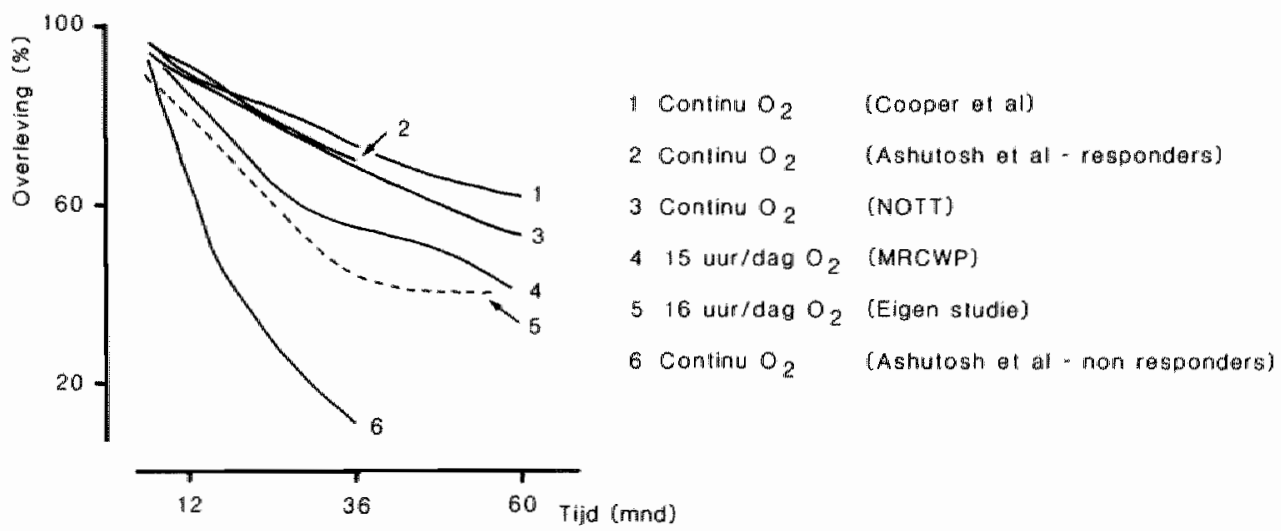


115 patiènten bleek de overleving gerelateerd aan de arteriële gaswaarden bij kamerlucht en niet aan bijvoorbeeld de rechterventrikel-ejectiefractie [France et al 1988]. Op deze studie valt echter wel kritiek te oefenen gezien de grote variatie in FEV, en gaswaarden; voorts hadden 43 patienten tekenen wan een gedecompenseerd cor pulmonale ten tijde van de studie. De resultaten van onze eigen studie bevestigen overigens de belangrijke betekenis van de gemengd-veneuze zuurstofbepalingen.

Gezien de behandeling met OZT, lijkt het echter zuiverder de vergelijking aan te gaan met de overige lange-termijn-zuurstofstudies. In figuur 7.5 en tabel 7.4 zijn de belangrijkste variabelen en de overleving samengevat. Het blijkt dat de overlevingscurves in de MRCWPen in onze eigen studie goed overeenkomen.

$\mathrm{Bij}$ het overzien van de prognostische variabelen blijkt er nogal wat verschil te bestaan tussen de diverse onderzoeken. De Britse studies, die elkaar (groten)deels overlappen, geven het belang van de longfunctie aan. De bepaling van de arteriële gaswaarden, hetzij bij kamerlucht, hetzij bij zuurstoftoediening, komt in geen van de studies naar voren als een belangrijke maat, wanneer OZT gestart wordt. De gemengd-veneuze zuurstofbepalingen, weel meer een parameter voor de weefseloxygenatie, komt in de andere studies niet ter sprake.

Tabel 7.4: Prognostische factoren tijdens OZT in verschillende studies.

\begin{tabular}{|c|c|c|c|c|c|c|}
\hline variabele & eenheid & MRCWP & NOTT & Cooper & Ashutiosh & $\begin{array}{l}\text { eigen } \\
\text { studie }\end{array}$ \\
\hline \multicolumn{7}{|l|}{ patiënten } \\
\hline aantal & & 42 & 101 & 72 & 43 & 49 \\
\hline leeftijd & (jaren) & 57 & 65 & 60 & 60 & 68 \\
\hline MPAP & (nmHg) & 34 & 30 & 28 & 34 & 23 \\
\hline $\mathrm{FEV}_{\downarrow}$ & (I) & 0.72 & & 0.78 & 0.82 & 0.85 \\
\hline \multicolumn{7}{|l|}{ prognostische factoren } \\
\hline longfunctie & & nee & nee & ja & ja & nee \\
\hline $\mathrm{PaO}_{2}$ (kamerlacht) & & nee & nee & nee & & \\
\hline $\mathrm{PaO}_{2}\left(\right.$ met $\left.\mathrm{O}_{2}\right)$ & & nee & & nee & & nee \\
\hline $\mathrm{PvO}_{2}\left(\right.$ met $\left.\mathrm{O}_{2}\right)$ & & & & & & ja \\
\hline $\mathrm{Hb}$ & & $?$ & & & & nee \\
\hline $\mathrm{PaCO}_{2}$ & & $?$ & nee & nee & & nee \\
\hline$\triangle \mathrm{MPAP}\left(\mathrm{na} \mathrm{O}_{2}\right)$ & & & & & ja & \\
\hline SVI & & & ja & & & nee \\
\hline$\triangle \mathrm{mPAP}$ (na 6 mind OZT) & & ja & & & & \\
\hline inspanningsonderzoek & & & & & ja & \\
\hline
\end{tabular}


Alle studies zijn het eens over de betekenis van de mPAP en de CI, maar de prognostische waarde van deze variabelen valt weg wanneer OZT wordt gegeven. Dat geldt niet wanneer de hartfrequentie in de analyse wordt betrokken; in de NOTT speelde de basale SVI een rol en in onze eigen studie de HF zelf. (figuur 7.3). De haemodynamische onderzoekingen van Ashutosh en die in de NOTT wijzen op de reversibiliteit van de mPAP als prognostische factor.

In onze eigen studie blijkt het belang van het zuurstofaanbod en -verbruik voor de overleving nog eens uit de overlevingscurves in relatie tot het totale transport voor zuurstof en de extractieratio (figuur 7.4 en 7.6 ).

De invasieve onderzoekingen uit alle studies maken de behoefte duidelijk aan eenvoudige klinische parameters die de overleving tijdens OZT zouden kunnen voorspellen. In de studie van Ashutosh en medewerkers bleken de sensitiviteit en specificiteit voor het voorspellen van de overleving na 3 jaar, respectievelijk 0.84 en 0.73 bij een $\mathrm{FEV}_{1}>0.85$ liter, en 0.62 respectievelijk 0.76 bij een $\mathrm{PaCO}_{2}>50 \mathrm{mmHg}$.

In ons eigen onderzoek bleken de waarden voor eenvoudig te meten variabelen als de HF, $\mathrm{PaCO}_{2}, \mathrm{FEV}_{1}$ en $\mathrm{SvO}_{2}$ niet zo voorspellend voor de overleving als verwacht (tabel 7.5). Indien na 1 en 3 jaar vervolg de variabelen worden getoetst (na 1 jaar voor 42 patiënten, na 3 jaar voor 31 patiënten) valt op dat tijdens OZT vooral de voorspellende waarden van de $\mathrm{SvO}_{2}$ en het totale zuurstoftransport van belang zijn. Een opmerkelijke bevinding is wel het feit dat de voorspellende waarde van elke variabele afneemt met de duur van de

Figuur 7.6: Invloed van de extractieratio op de overlewing.

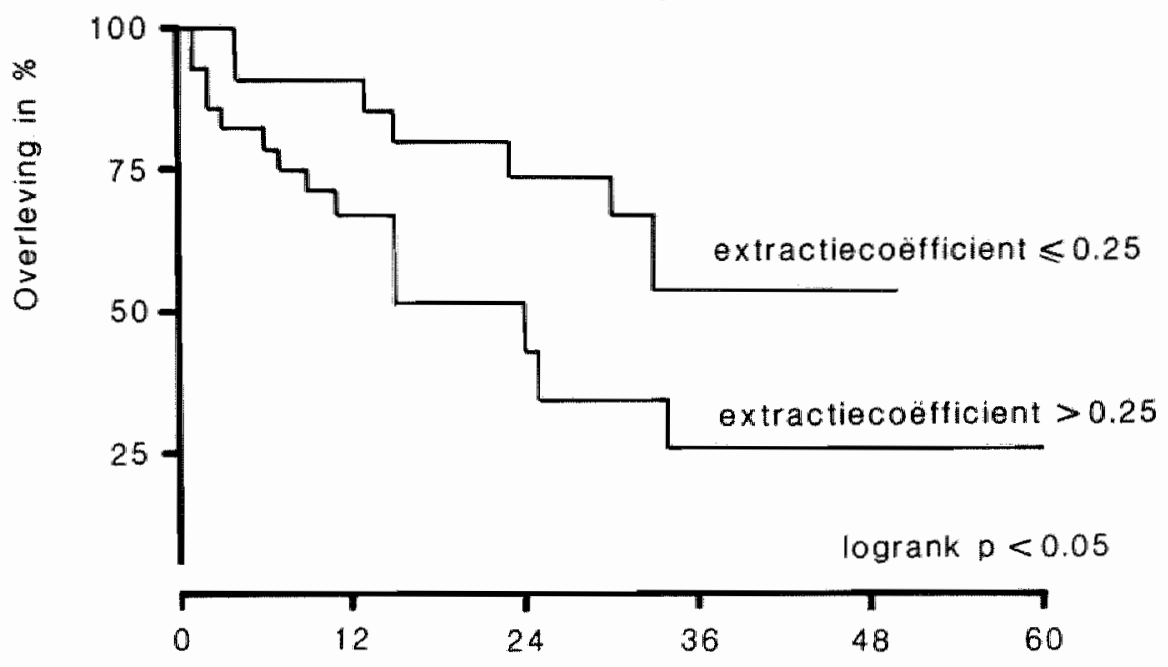


Tabel 7.5: De senisifiviteit, specificiteit, validiteit en voorspellende waarde van enkele parameters met. betrekking tot de overleving na 1 en 3 jaar follow-up.

\begin{tabular}{|c|c|c|c|c|c|c|}
\hline . & $\because \ldots$ & : : & $\begin{array}{c}\text { sensitiviteit } \\
\text { (\%) }\end{array}$ & $\begin{array}{l}\text { specifiteil } \\
\text { (o) }\end{array}$ & $\begin{array}{l}\text { validiteit } \\
\text { (\%) }\end{array}$ & $\begin{array}{c}\text { voorspellende } \\
\text { waarde } \\
\text { (\%) }\end{array}$ \\
\hline \multirow{2}{*}{$\mathrm{HF} \leq 90$} & \multirow{2}{*}{ slagen $\min ^{-1}$} & $1 \mathrm{jr}$ & 50 & 56 & 76 & 78 \\
\hline & & $3 \mathrm{jr}$ & 58 & 80 & 35 & 50 \\
\hline \multirow{2}{*}{$\mathrm{PaCO}_{2} \leq 50$} & \multirow{2}{*}{$\operatorname{minh} \mathrm{Hg}$} & $1 \mathrm{jr}$ & 20 & 75 & 76 & 75 \\
\hline & & $3 \mathrm{jr}$ & 32 & 70 & 35 & 35 \\
\hline \multirow{2}{*}{$\mathrm{FEV}_{1}>0.85$} & \multirow{2}{*}{1} & $1 \mathrm{jr}$ & 50 & 48 & 74 & 74 \\
\hline & & $3 \mathrm{jr}$ & 61 & 50 & 36 & 42 \\
\hline \multirow{2}{*}{$\mathrm{SvO}_{2}>75$} & \multirow{2}{*}{$\%$} & $1 \mathrm{jr}$ & 90 & 55 & 78 & 94 \\
\hline & & $3 \mathrm{jr}$ & 95 & 30 & 35 & 75 \\
\hline \multirow{2}{*}{ MAP $>85$} & \multirow{2}{*}{$\mathrm{mmHg}$} & $1 \mathrm{jr}$ & 60 & 72 & 76 & 85 \\
\hline & & $3 \mathrm{jr}$ & 53 & 92 & 39 & 55 \\
\hline \multirow{2}{*}{$\mathrm{SOT}>1200$} & \multirow{2}{*}{$\mathrm{mll}_{n} \min ^{-1}$} & 1. $\mathrm{jr}$ & 78 & 53 & 77 & 89 \\
\hline & & $3 \mathrm{jr}$ & 71 & 67 & 41 & 62 \\
\hline
\end{tabular}

overleving. De voorspellende waarde lijkt dus vooral van belang voor de kortere termijn. Deze gegevens herinneren aan de opvallende bevindingen in de MRCWP-studie, waar in het eerste 1.5 jaar geen verschil tussen de groepen met en zonder OZT werd waargenomen. De voorspellende warden van $\mathrm{SvO}_{2}$ en SOT in onze studie suggereren ook dat sommige patiexnten met lage $\mathrm{SvO}_{2}$ en SOT niet meer in staat zijn van OZT te profiteren. 


\section{$8 \quad$ Nabeschouwing}

\subsection{Methodologische aspecten}

Bij de bespreking van de resultaten in dit onderzoek dienen enkele methodologische aspecten benadrukt te worden. De haemodynamiek bij het chronisch obstructief longlijden hangt sterk af van de gaswisseling, waarbij hypoxie en hypercapnie belangrijke invloeden op de circulatie uitoefenen. Indien zuurstof per neusslang toegediend wordt aan patiènten met chronische hypoxie, induceert deze maatregel veranderingen in gastransport en haemodynamiek [Corriveau et al 1989]. Hetzelfde fenomeen geldt bij het onthouden van zuurstof aan patiënten die ingesteld zijn op onderhoudsbehandeling met zuurstof thuis [Selinger et al 1987]. De veranderingen in haemodynamiek treden vrij acuut op en stabiliseren zich pas na enkele uren. Met deze gegevens in gedachten, is het logisch dat elkaar snel opvolgende interventies met zuurstof en/of vaatwerwijders bij hypoxische patiënten, de interpretatie van vastgestelde effecten bemoeilijkt. Als voorbeeld kan gesteld worden, het toedienen van een vaatverwijder aan patiënten bij wie zojuist de toediening van zuurstof gestakkt is. Vrijwel zeker zal de vaatverwijder de reflectoire vasoconstrictie blokkeren [Rubin en Moser 1986]. Indien de effecten van zuurstoftoediening en vaatverwijders apart bestudeerd worden bij dezelfde patiënt, verdient het aanbeveling de interventie op verschillende dagen te doen plaatsvinden vanuit dezelfde basisomstandigheden [Kennedy et al 1984].

In de behandeling van het hypoxisch longlijden heeft de thuisbehandeling met zuurstof zich een vaste plaats verworven, terwijl de rol van vaatverwijders nog niet duidelijk is [Whyte en Flenley 1989]. Wij kozen voor het verrichten van onderzoek tijdens normoxie. Door uitsluiting van patiënten, die reeds met zuurstof thuis behandeld waren, kon de pathofysiologie tot aan de start van de behandeling met zuurstof thuis bestudeerd worden. Een tweede keuze betrof het uitvoeren van de onderzoekingen in rust. Het voordeel van dit onderzoeksmodel is de mogelijkheid tot afname van de bloedmonsters voor de basale hormoonwaarden en nierdoorbloeding. Een nadeel is het ontbreken van inspanningsonderzoek, op zich zelf een bron van waardevolle diagnostische informatie [Murphy et al 1989].

Een formeel punt betreft het gebruik van variabelen als vaatweerstanden en zuurstofverbruik en -transport. Voor al cleze variabelen geldt dat ze afgeleid zijn van directe bepalingen, waaronder het hartminuutvolume. Deze afleidingen hebben tot gevolg dat de variabelen rekenkundig niet onafhankelijk van elkaar zijn [Vermey 1990]. 
Zo werden in dit proefschrift de SOT en $\mathrm{VO}_{2}$ beide berekend met behulp van de met de thermodilutiemethode gevonden waarde van het hartminuutwolume. Om deze reden worden de verbanden tussen zuurstoftransport (SOT) en zuurstofverbruik $\left(\mathrm{VO}_{2}\right)$, en ook tussen pulmonale en systemische vaatweerstand niet besproken. Gezien de belangstelling in de literatwur voor de afhankelijkheid van zuurstofverbruik en -transport [Brent et al 1984], lijken onafhankelijke bepalingen van de $\mathrm{VO}_{2}$ en SOT een noodzakelijk [Lanigan 1990].

Hoewel het idee van de transportafhankelijke zuurstofbehoefte op theoretische gronden dus niet juist is, blijkt in de praktijk toch de afhankelijkheid gepaard te gaan met toegenomen morbiditeit en mortaliteit [Shoemaker 1988]. In de klinische setting van de intensive care heeft dit geleid tot het advies de gemengd-veneuze zuurstofsaturatie te meten en de zuurstofopname te optimaliseren [Vincent 1990].

\subsection{Haemodynamische aspecten van het cor pulmonale}

In figurur 8.1 zijn de diverse verbanden en mechanismen die zullen besproken worden, weergegeven. Zoals eerder in het literatuuroverzicht vermeld, zijn in het verleden twee theorieën naar voren gekomen met betrekking tot de vorming van oedeem: forward failure en backward failure.

De verschillende mechanismen bij forward en backward failure kunnen verklaard worden door de introductie van de term "effectief circulerend volume" [Schrier 1988]. Het gebruik van deze term kan zowel de oedemen bij congestief hartfalen als bij levercirrhose verklaren. Voorheen is ook de vulling van het arteriële vaatbed als een belangrijke factor in de pathogenese van de water- en zoutretentie beschouwd [Borst en Borst-de Geus 1963, Skorecki en Brenner 1982]. Het hart bepaalt de perfusiedruk voor de weefsels. De lokale weefseldoorbloeding hangt dan af van de perfusiedruk en de vaatweerstand. In het arteriële vaatstelsel (normaliter $15 \%$ van het totale bloedvolume) wordt de vulling bepaald door hartminuutvolume, vaatbedcapaciteit en vaatweerstand.

In geval van linker-ventrikelfalen en decompensatio cordis is er sprake van een laag hartminuutvolume en een hoge vaatweerstand. Door receptoren in het vaatbed en inadequate perfusie worden de sympathicus, het renine-angiotensine-aldosteron systeem en vasopressine gestimuleerd. 
Figuur 8.1: Enkele werbanden tussen respiratoire en circulatoire paraneters, zoals in dit proefschrift vastgesteld.

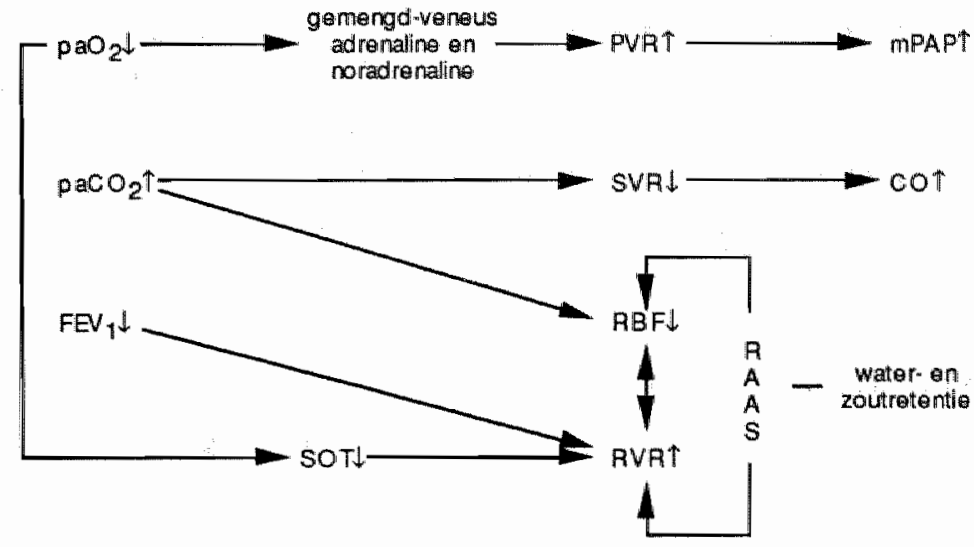

Bij het cor pulmonale ten gevolge van chronisch obstructief longlijden is de situatie verschillend van die bij het linker-ventrikelfalen. Zoals ook de gegevens uit hoofdstuk 4 tonen, is er veelal sprake van een normaal tot verhoogd hartminuutvolume [Matthay 1983], hetgeen de theorie van een verminderd effectief circulerend volume minder aannemelijk maakt. Ook bij inspanning lijkt de cardiale respons normaal [Khaja 1971]. Onze gegevens laten bovendien een normale arbeidsindex zien voor de linker ventrikel in rust, terwijl de rechterventrikelarbeidsindex in de helft van de patiënten verhoogd bleek te zijn. Dit alles in aanwezigheid van een normale wiggedruk. Deze gegevens stemmen overeen met literatuurgegevens waaruit blijkt dat bij deze patiënten slechts bij uitzondering een linkerventrikeldysfunctie of coronair lijden geobjectiveerd kan worden [Steele ef al 1975]. Aldus ziet het ernaar uit dat de haemodynamische situatie die gevonden wordt bij het obstructief longlijden, overeenkomsten vertoont met die welke kunnen optreden in het kader van anemie of hyperthyreoïdie. In deze visie zijn het de metabole behoeften van de organen die primair verantwoordelijk zijn voor de haemodynamische aanpassing. Bij het hypoxisch obstructief longlijden gaat de stimulus uit van de initiële verlaging wan de zuurstofspanning in de weefsels. Via het mechanisme van de autoregulatie leidt dit tot arteriolaire vasodilatatie [Fishman et al 1951] met secundair toeneming van het hartminuutvolume, zodat er geen sprake is van een verminderd effectief circulerend volume.

Pas veel later, nadat de pulmonale vaatweerstand sterk gestegen is en de rechterventrikelfunctie duidelijk gecompromitteerd is, ontstaat een situatie die vergelijkbaar is met 
het falen van het linker ventrikel. Doch initieel, als nog geen hypercapnie bestaat, zal er geen neiging tot natriumretentie optreden.

Een probleem waar wij ons nu voor gesteld zien, is het feit dat ondanks het normale of hoge hartminuutvolume de nierdoorbloeding laag is en het renine gestimuleerd. De haemodynamische gegevens en het ontbreken wan verhoogde arteriele catecholamines sluiten een verminderde vullingstoestand uit. Bovendien gebruikten slechts enkele van onze patiënten diuretica. Andere mechanismen dienen derhalve verantwoordelijk te zijn voor de renale vasoconstrictie.

Op grond van de gegevens uit hoofdstuk 4 , het verband tussen nierdoorstroming en de expiratoire één seconde waarde $\left(\mathrm{FEV}_{1}\right)$, kan verondersteld worden dat beperking van de longfunctie een rol speelt. Een mogelijke verklaring lijkt de invloed van intra-thoracale drukveranderingen op de veneuze terugstroom naar het hart, doch als dit het geval zou zijn, zou men een lager hartminuutwolume verwachten. Een tweede mogelijkheid is dat het effect van de longfunctiestoornis verloopt via een stijging van de intra-abdominale druk. Recent is namelijk vanuit de intensive care literatur gewezen op intra-abdominale drukverhoging als oorzaak van nierfunctieverlies en verminderde natriurese [Platell et al 1990]. Voorts is in onderzoek bij dieren aangetoond dat drukverhoging in de vena renalis leidt tot natriumretentie [Burnatt en Knox 1980]. Deze samenhang tussen intra-thoracale en intraabdominale drukveranderingen met betrekking tot de nierfunctie verdient nader onderzoek, bijwoorbeeld tijdens perioden van mechanische ventilatie met positief eindexpiratoire druk [Neidthart en Suter 1988].

Op grond van deze gegevens is uiteraard de gevonden renine-stimulatie nog niet afdoende verklatard. Dit voert ons terug naar een andere relatie uit hoofdstuk 4 , het omgekeerd verband tussen het arteriële $\mathrm{CO}_{2}$-gehalte $\left(\mathrm{PaCO}_{2}\right)$ en de nierdoorstroming. Deze relatie werd eerder vastgesteld bij hypoxische patiënten [Farber en Mantredi 1984]. Tevens stelden wij een toegenomen reabsorptie van $\mathrm{HCO}_{3}{ }^{-}$vast, hetgeen normaliter alleen gebeurt in situaties van duidelijke ondervulling [Logan en Alpern 1984].

Derhalve komen wij tot de hypothese dat een toegenomen $\mathrm{PaCO}_{2}$ in het nierweefsel leidt tot lokale activering van het renine-angiotensine-aldosteron systeem. Deze activering zou kunnen berusten op intra-cellulaire acidose in de proximale tubuluscellen. Een dergelijke ontregeling zal namelijk gevolgd worden door versterkte reabsorptie $\mathrm{HCO}_{3}$, een proces dat mede gestuurd wordt door de zogenaamde $\mathrm{Na}^{+}-\mathrm{H}^{+}$antiporter in de luminale membraan van de tubuluscel. De activiteit van de antiporter neemt toe onder invloed van angiotensine II; 
evenwel werkt stijging van dit hormoon renale vasoconstrictie en daling van de doorstroming in de hand.

Het wordt ook duidelijk waarom natriumretentie pas laat, in de hypercapnische fase, optreedt. Gewoonlijk gaat renale vasoconstrictie gepaard met suppressie van het renine [Birkenhăger en de Leeuw 1987] en blijft de neiging tot natriumretentie beperkt. In geval van hypercapnie echter zal gelijktijdige stimulatie van het intra-renale renine-angiotensinealdosteron systeem en van de antiporter tot ongebreidelde retentie aanleiding geven.

De geretineerde hoeveelheid water en zout zal zich over het extra-cellulaire compartiment verdelen en aanleiding kunnen geven tot oedeem. Dit verklaart bijvoorbeeld onze bevinding dat het aldosteron niet sterk gestegen is. Volume-expansie heeft namelijk een remmend effect op de aldosteron-afgifte. Omdat de renale vasoconstrictie en stimulatie van renine niet door een primair haemodynamische prikkel worden onderhouden, blijft de retentie doorgaan tot een punt waarop de circulatie overbelast raakt en het klinische beeld van het cor pulmonale ontstaat. Bij ernstige vormen van obstructief longlijden gaat de secundaire polycythaemie mede een rol spelen. Via toegenomen viscositeit en verminderde veneuze terugstroom [Guyton 1957] neemt de post-capillaire weerstand in de weefsels toe en wordt de uittreding van vocht in de weefsels bevorderd. Toenemende retentie van water en zout komt nu vrijwel niet meer ten goede aan het intravasculaire compartiment waarop uiteindelijk het rechter ventrikel onvoldoende gevuld wordt. Dit luidt de fase in waarin het beeld van het cor pulmonale vooral bepaald gaat worden door de sterk gestegen weerstand in het pulmonale vaatbed.

\subsection{De arteriële bloeddruk en het cor pulmonale}

Samenvattend kunnen we de invloeden van de gaswisseling en de longfunctie op de nier als primair beschouwen. Daartegenover stellen we de gevolgen van de verstoorde doorbloeding, zich uitend in de activatie van het RAAS als secundair. Bij de patiënten, wier activiteit van het RAAS bestudeerd werd, was een verhoging van de renine-spiegels de meest opvallende bevinding. Van de verschillende variabelen correleerden de veneuze renine- en angiotensine II-spiegels omgekeerd met de renale plasmastroom. De activatie van het RAAS zou een van de factoren kunnen zijn die de vastgestelde relatie tussen de arteriële en pulmonale bloeddruk kan verklaren, onafhankelijk van de vullingsstatus.

Immers bij hypertensie en linker-ventrikelfalen verloopt de relatie MAP - mPAP volgens een te beredeneren mechanisme. Een verhoging van de MAP en/of toename van het linkerventrikelvolume leidt tot een verhoogde wiggedruk en secundair tot een toename van de 
mPAP. Ook bij ongecompliceerde hypertensie zijn er aanwijzingen dat de wiggedruk de link vormt tussen pulmonale en arteriële druk. Fagard en medewerkers onderzochten 71 patiënten en stelden een directe relatie vast tussen de MAP en mPAP. Bij multivariate analyse bleek vervolgens de wiggedruk de belangrijkste schakell tussen deze twee. Daarentegen valt in de door ons gepresenteerde gegevens een omgekeerd patroon waar te nemen. Er bleek sprake van een normale arbeidsindex van het linker ventrikel, een normaal minuutvolume en wiggedruk. Bij verdere analyse bleek de MAP, naast de $\mathrm{PaCO}_{2}$, het meest gerelateerd aan de mPAP, waarbij de invoering van de wiggedruk het model ongewijzigd liet.

Naast de invloed van het RAAS en het andrenerge systeem (te bespreken in 8.4), secundair aan de verstoring van gaswaarden en de longfunctie, kan gedacht worden aan de invloed van erythropoietine, secundaire polycythaemie en viscositeitsproblemen op de hoogte wan de bloeddruk. Gegevens uit de literatuur steunen de opvatting dat bij het chronisch obstructief longlijden meer hypertensie voorkomt. Sparrow en medewerkers vervolgden prospectief 1270 mannen voor meer dan 10 jaar en vonden na correctie voor de leeftijd dat de FEV geassocieerd was met de ontwikkeling van hypertensie [Sparrow et al 1988]. Deze waarnemingen werden niet beïnvloed door nicotinegebruik. Tevens was hypoxie als oorzaak uitgesloten.

Een geheel nieuw gebied in het hypertensie- en circulatieonderzoek wordt gevormd door de endocriene rol van de vaatwand en bloedplaatjes. Tal van factoren als serotonine, de van enclotheel afhankelijke relaxerende factor (EDRF) en endotheline-1 zijn de laatste jaren bestudeerd. Chronische vaatwandafwijkingen bij hypertensie en atherosclerose gaan gepaard met een verlies aan EDRF [Vanhoulte 1991]. Omgekeerd heeft het endotheline-1 juist krachtige vasoconstrictoire eigenschappen, met name renaal [Vane et al 1990]. Het peptide stimuleert de afgifte van aldosteron en catecholamines. Verhoogde plasmaspiegels zijn beschreven bij patiënten met essentiële en pulmonale hypertensie.

Het moge duidelijk zijn dat het endotheel zeer wel de relatie tussen pulmonale en systemische bloeddruk kan verklaren bij het chronisch longlijden. Naast het specifieke vaatonderzoek opent dit perspectieven voor de therapie met vaatverwijders. Zo zijn van de serotonine- 2 receptorantagonist ketanserin, een gecombineerd arterioveneuze vaatverwijder, gunstige effecten beschreven op de pulmonale shuntfractie en de nierdoorbloeding (Lameire et al 1990, Van der Starre 1988]. 


\subsection{Het sympatisch zenuwstelsel en het pulmonale vaatbed}

De betrokkenheid van het sympathicussysteem als regulatiemechanisme voor de tonus van de longarteriën, is een voor de hand liggende verklaring voor diverse correlaties. Overigens geldt voor de sympathicusactiviteit, dat spiegels van catecholaminen slechts een matige afspiegeling zijn van hetgeen op lokaal (weefsel- of orgaan-)niveau geschiedt.

De rol van de sympathicus komt vooral naar voren in de betrekkingen tussen de arteriële gaswaarden en de vaattonus in het veneuze stelsel.

In verschillende publikaties is gewezen op de invloed van de $\mathrm{PaO}_{2}$ en $\mathrm{PaCO}_{2}$ op de produktie van catecholamines als mechanisme voor de pulmonale hypertensie. Hypoxie lijkt zowel chemoreceptoren in de aortaboog te prikkelen als lokaal in de arteria pulmonalis te leiden tot overproduktie van catecholamines. Studies bij proefdieren, die hypoxaemisch gemaakt werden, toonden aan dat er haemodynamische aanpassingen ontstonden in de vorm van toename van contractiliteit van het myocard en stijging van de pulmonale vaatweerstand. Achtereenvolgens werden deze dieren geperfundeerd met normoxaemisch bloed en werd denervatie van de carotis-chemoreceptoren werricht [Barer en Pallot 1986]. Na beide manoeuvres werden onder invloed van hypoxie geen haemodynamische aanpassingen meer waargenomen. De resultaten vermeld in hoofdstuk 4, wijzen eveneens in de richting van hypoxie als een belangrijk factor voor de activatie van de sympathicus. Ondanks ons streven naar normoxie bij de patiëntengroep, bleken de gemengd-veneuze catecholamines duidelijk gerelateerd aan de arteriële zuurstofspanning en -saturatie. Daarbij valt op dat de verbanden tussen sympathicusactiviteit en gaswaarden niet op gingen voor de arteriële catecholamines en de gemengd-veneuze gaswaarden. De lokale beïnloeding van de sympathicusactiviteit zou de tendens tot lagere waarden van de arteriële catecholamines kunnen verklaren.

Binnen het kader van de catecholamines valt de dominante rol van de adrenaline-spiegels op. Het overwegen van het adrenaline zou kunnen berusten op de affiniteit voor de $\beta 2$-receptor in de pulmonale vaatwand en de long. In het algemeen veroorzaakt stimulatie van de $\beta 2$-receptor in het vaatbed een vasodilatatie, in de long een bronchodilatatie en wat het hart betreft een toename van de contractiliteit en het minuutvolume. Daarnaast kan op beperkte schaal $\alpha$-stimulatie met vasoconstrictie optreden. De invloed van adrenaline verloopt echter niet alleen direct, doch ook indirect door middel van secerneren van noradrenaline na stimulatie van presynaptische $\beta_{2}$-receptoren. 


\subsection{Het veneuze vaatbed}

In de bespreking van het sympathische zenuwstelsel lijkt naast de pulmonale vasoconstrictie ook de tonus van het veneuze capaciteitsbed wan belang. Uit literaturgegevens is bekend dat de sympathicus daarin een belangrijk rol speelt. Wanneer een stof als noradrenaline geînfundeerd wordt, leidt dit tot beperking van de veneuze compliantie en verkleining van het plasmavolume, waardoor de hematocriet en de viscositeit stijgen [Cohn 1966]. In chronische situaties gaat stijging van de viscositeil gepaard met een verhoogde kans op cardiovasculaire complicaties [Kannell 1972]. Indien het bloedvolume ongewijzigd blijft, leidt veneuze constrictie tot redistributie van bloed met overvulling van het arteriële stelsel [Isbister 1990]. Pathofysiologisch is de veneuze constrictie wel te begrijpen: hypoxie leidt tot toename van de afterload van de rechter ventrikel. Een toename in contractiliteit en preload kan daarbij compensatoir het hartminuutvolume op peil houden.

Er zijn verscheidene studies bekend waarin de acute effecten van zuurstof op de haemodynarniek bestudeerd zijn [Corriveau el al " 989 , Degaute et al 1981, Hunt et al 1989]. Degaute onderzocht 35 patiënten in de acute fase van een gedecompenseerd cor pulmonale. Hij verdeelde de patiënten in 2 groepen met ernstige respectievelijk milde hypoxie. $\mathrm{Na}$ toediening van zururstof $\left(\mathrm{FiO}_{2} 28 \%\right)$ in de groep met ernstige hypoxie (bij kamerlucht was de $\mathrm{PaO}_{2} 40 \mathrm{mmHg}$ ) bleef het hartminuutvolume gelijk en steeg het zuurstoftransport (SOT). Daarentegen daalde in de groep met milde hypoxie $\left(\mathrm{PaO}_{2} 49 \mathrm{mmHg}\right.$ bij kamerlucht $)$ het hartminuutvolume zodat de SOT gelijk bleef ondanks de toename in de arteriële zuurstofhoeveelheid. De uitgangswaarde voor het hartminuutvolume was in beide groepen gelijk. In de studie wan Hunt en medewerkers worden de effecten beschreven na toediening van $100 \%$ zuurstof aan stabiele hypoxische patiënten [Hunt et al 1989]. Zowel de mPAP als het minuutvolume daalden, terwijl ook de effectieve pulmonale bloedstroom daalde. Deze laatste daling, gemeten via de rebreathing methode, stemde overeen met de daling van de mPAP. Ook Corriveau nam waar dat zuurstoftoediening bij hypoxische patiěnten haemodynamische veranderingen veroorzaakte, Bij een kleine groep patiënten $(n=11)$ vond hij dat in de subgroep met uitgesproken hypoxie, zuurstoftoediening het hartminuutvolume licht deed stijgen, terwijl deze daalde bij patiënten met milde hypoxie. De omgekeerde procedure, het staken van zuurstoftoediening bij patienten ingesteld op OZT, is eveneens verricht [Selinger et al 1987]. Het verwijderen wan de supplementele zuurstoftoediening veroorzaakte een stijging in de mPAP, die gerelateerd was aan de daling in de $\mathrm{PaO}_{2}$. De patiënten die tijdens OZT normocapnisch waren, bleken in staat te zijn het zuurstoftransport op peil te houden. Daarentegen daalde het zuurstoftransport en -verbruik in hypercapnici. 
De interpretatie van deze gegevens is niet eenvoudig. Het lijkt erop dat door toediening van zuurstof aan de hypoxische patiënt een vasodilatatie van het veneuze systeem optreedt. Daardoor daalt de preload en secundair het hartminuutvolume en de MPAP. Twee andere alternatieven voor het mechanisme van de daling in mPAP en hartminuutvolume zouden kunnen zijn: een vermindering van de contractiliteit van het hart of stijging van de pulmonale vaatweerstand. Nu lijkt het niet logisch een verminderde contractiliteit of pulmonale vasoconstrictie te koppelen aan zuurstoftoediening. De vraag is dan op welke wijze de veneuze tonus bij deze patiënten geregeld is. Het artikel van Hunt vermeldt twee mogelijke mechanismen waardoor zuurstoftoediening een vasodilatatie en een daling van de mPAP veroorzaakt: enerzijds directe invloed van de sympathicus op de vaatwand, geluxeerd door hypoxie, anderzijds het onderbreken van de reflexbogen die verlopen via carotis- en aortale chemoreceptoren, welke op hypoxie reageren met stimulatie van het hart. De gegevens in dit proefschrift sluiten beide mogelijkheden niet uit. Het is duidelijk dat dit concept zich onderscheidt van de tot nu toe gevolgde theorie over de invloed van zuurstof op de arteria pulmonalisdruk [Ashutosh et al 1987]. In deze theorie wordt gesteld dat het doorbreken van de hypoxische vasoconstrictie in de arteria pulmonalis, een voorspellende waarde heeft voor de overleving tijdens OZT.

Een voordeel van de studie van Ashutosh is dat deze responders en non-responders op zuurstof onderscheidt. Op grond van deze studie heeft Morrison de rechter-ventrikelhypothese geformuleerd. Pulmonale hypertensie beperkt de kwaliteit van leven en de levensduur bij chronisch obstructief longlijden door middel van een vermindercle rechterventrikelfunctie (diastolisch en systolisch) [Morrison 1987]. De hypothese kan aangescherpt worden door de toevoeging dat in de pathofysiologie van het cor pulmonale, de veneuze terugstroom en de regulatie van de vulling en tonus van het veneuze bed een belangrijke rol spelen en mogelijk de mPAP-daling verklaren.

Het lijkt logisch het onderzoek op dit gebied verder uit te breiden. Zowel de niet-invasieve diagnostiek van de pulmonale bloeddoorstroming als de vastlegging van de neuro-endocriene status voor en na zuurstoftherapie zouden kunnen bijdragen aan een verfijning van de voorspelling welke patiënt optimaal van OZT zal kunnen profiteren.

\subsection{Therapeutische aspecten}

Heeft het concept van de preload en de regulatie van het veneuze vaatbed consequenties voor de therapie? 
Indien de overwegingen voor therapie vergeleken worden met de therapie van decompensatio cordis op basis van linker-ventrikelfalen, worden ze van meer dan theoretisch belang. Bij de behandeling van de chronische decompensatio cordis zijn tot nu toe slechts enkele middelen in staat gebleken de overleving van de patiënten te verbeteren. Opvallende genoeg betreft het regimes die naast arteriële ook veneuze vaatverwijding geven, namelijk ACE-inhibitors en de combinatie van nitraten met apresoline [Cohn 1986, Concensus 1987. SOLVD 1991].

De hier gepresenteerde gegevens geven voor enkele patiëntengroepen aan, hoe de additieve effecten van vaatverwijders met betrekking tot zuurstoftoediening verlopen. Nifedipine, als typische arteriële vaatverwijder veroorzaakte een vasodilatatie bij gelijkblijvende vullingsdrukken. De systemische effecten gingen niet gepaard met essentiële veranderingen in de gaswaarden. Captopril werd getest in een kleinere groep van patiënten, De gekozen dosering beïnvloedde de systemische haemodynamiek nauwelijks, terwijl zich een tendens tot daling van de wiggedruk en atriumdrak aftekende. In de bestudering van de hormonale bepalingen valt op dat nifedipine de catecholamines en renine licht doet stijgen. Deze observatie bevestigt gegevens dat nifedipine cardiopulmonale chemoreceptoren stimuleert en zo de sympathicusactiviteit verhoogt [Ferguson 1990]. De interactie tussen RAAS en sympathicus zou kumnen verklaren dat in beide systemen een zelfde trend wordt waargenomen na nifedipine [Siedelin 1989].

Captopril veroorzaakte een daling van de A II-spiegel, zoals te verwachten, waarbij het renine steeg, en de catecholamines gelijk bleven of licht stegen. In de literatuur wordt een zelfde trend waargenomen. Remming van het ACE-systeem in normotensieven en hypertensieven lijkt de sympathicus weinig te beïnwloeden, terwijl soms een parasympathicomimetisch effect gezien wordt [Crozier 1989]. Zoals eerder in dit hoofdstuk besproken, wordt het belang van de endotheelfunctie en lokale RAAS groot geacht, zeker indien de krachtige effecten van A II (vasoconstrictief, celproliferatie) in acht worden genomen [Frohlich et al 1989]. Verder onderzoek, misschien met een lage-dosis ACE-remmer of serotonine-antagonist om systemische effecten te minimaliseren, zal moeten bewijzen of de theoretische overwegingen juist zijn.

\subsection{De overleving}

De gegevens uit hoofdstuk 7 met betrekking tot de overleving snijden het mechanisme aan, dat de overleving tijdens zuurstoftherapie bepaalt. 
De rol van de haemodynamiek is vooral in de Nocturnal Oxygen Therapy Trial (NOTT) onderzocht. Zeven parameters uit de haemodynamiek werden geèvalueerd: de $\operatorname{RAP}_{n}$ de mPAP, CI, SVI, PVR en RVSWI. In de follow up bleek dat de daling van de mPAP in het eerste half jaar prognostisch betekenis had. De eerder geciteerde Ashutosh studie over de acute effecten van zuurstof op de mPAP, steunt het concept van de reversibele pulmonale hypertensie als maat voor het te verwachten succes van OZT [Ashutosh et al 1987, Timms et all 1985].

Op grond van deze studies en de gedachte dat toename van het hartminuutvolume het zuurstoftransport verder verbetert, zijn de theorieën ontstaan dat vaatverwijders de overleving verder zouden kunnen beïnvloeden. Tot nu toe zijn echter slechts weinig studies over lange termijn effecten van vaatverwijders gepubliceerd. In een studie met nifedipine bleek de overleving niet te verbeteren na anderhalf jaar follow up [Vestri 1990].

Om welke mechanismen gaat het precies naast de voldoende oxygenatie van het bloed. Enerzijds is er het zuurstoftransport, beïnvloedt door opgeloste zuurstofhoeveelheid en minuutvolume. Anderzijds is er de lokale behoefte aan zuurstof, die afhangt van de arbeid te verrichten, en van de lokale vasoregulatie. Bij toenemende verstoring van de longfunctie blijkt de adem arbeid en dus de zuurstofconsumptie ten behoeve van de longen toe te nemen [Lanigan 1990].

De gegevens uit hoofdstuk 7 wijzen verschillende mechanismen aan, betrokken bij de overleving, nadat zuurstoftherapie gestart is om hypoxaemie te corrigeren. De rol van de systemische bloeddruk is interessant. In de Cox-regressieanalyse was de bloeddrukfactor steeds van belang. Een lage bloeddruk was geassocieerd met een slechtere overleving dan een hogere druk. Voortbouwend op het mechanisme dat hypertensie een schadelijk gevolg is van de compensatoire krachten opgeroepen door chronische hypoxie en/of hypercapnie, zou men kunnen poneren dat een lage bloeddruk in gecompliceerd obstructief longlijden wijst op falende compensatie-mechanismen. De studie bevestigt de bevindingen uit de NOTT dat het hartminuutvolume of mPAP op zich geen voorspellende waarde heeft. Door de bloeddruk naar voren te halen, valt het accent op de capaciteit van het hart een voldoende druk (perfusiedruk) op te bouwen, ook in aanwezigheid van een lage vaatweerstand door hypercapnie. Gezien de aandacht voor de arteriële bloeddruk zou het interessant zijn de neuro-endocriene kenmerken met betrekking tot de overleving te bepalen voor een grote groep patiẻnten.

Daamaast vestigt hoofdstuk 7 de aandacht op de parameters met betrekking tot de weefseloxygenatie, zoals de gemengd-veneuze saturatie en zuurstofspanning, de 
extractiecoefficiènt en het zuurstoftransport. De overleving van de patiënten met een zuurstoftransport beneden $1200 \mathrm{milmin}{ }^{-1}$ was slecht. Op grond van literatuurgegevens is door Hurewitz geadviseerd on bij een zuurstoftransport $<800 \mathrm{ml} \cdot \mathrm{min}^{-1} \cdot \mathrm{m}^{-2}$ een vasodilatator toe te voegen an zutrstoftherapie [Hurewitz en Bergofsky 1988]. Gezien de sterk negatief voorspellende waarde woor de overleving van een lage gemend-veneuze saturatie, zou men praktisch uit kunnen gaan van de veneuze of capillaire zuurstofsaturatie. Toediening van zuurstof en vaatverwijder, met regelmatige bepaling van de veneuze saturatie, zou misschien de belastende rechtscatheterisatie kunnen vermijden.

Ook wat deze laatste gegevens betreft zou het interessant zijn verdere studies met ACEremmers en andere vaatverwijders te vernichten. Met het concept van voldoende perfusiedruk als mechanisme voor overleving woor ogen, lijkt het aantrekkelijk de effecten van lage-doses ACE-remmers te toetsen. Door bloeddrukdaling te vermijden en zuurstoftransport zowel systemisch als lokaal te verbeteren, zou misschien een verdere verfijning in de behandeling van het cor pulmonale aangebracht kunnen worden. 


\section{Literatuuropgave}

A ber G.M., Bishop J.M. Serial changes in renal function, arterial gastensions and the acid-base state in patients with chronic bronchitis and oedema. Clin Sci 1965;28:511-525.

Adamson J.W. The promise of recombinamt erythropout tin. Semin Hematol 1989;26 (suppl 2):5-8.

Adnot S., Andrivet P., Chabrier P.E., Picquet J., Plas P., Braquet P. Arrial natriuretic factor in chronic obstructive lung disease with pulmonary hypertension. J Clin Invest 1989; 83: 986-993.

Adnot S.y Chabrier P.E., Brun-Buisson C., Viossat 1., Braquet P. Atrial natriuretic factor (ANF) attenuates the pulmonary pressar response to hypoxia. J Appl Physiol 1988; 65: 1975-1983.

Agostoni P., Doria E., Galli C., Tamborini G., Guazzi M.D. Nifedipine reduces pulmonary pressure and wascular tone during short-bur not long-term treatment of pulmonary hypertension in patienis with chromic obstructive pumonary disease. Am Rev Respir Dis 1989; 139: 120-125.

Alderman M.H., Madhavan S., Ooil W.L., Cohen H., Sealy J.E., Laragh J.H. Association of the renin-sodium profile with the risk of myocardial infarction in patients with hypertension. $\mathrm{N}$ Engl J Med 1991; 324: 1098-1104.

Amery A., Birkenhäger W.H., Brixko P. et al. Mortuality and morbidity results from the Europecin Working Party on High Blood Pressure in the Elderly Trial. Lancet 1985; i: 1349-1354.

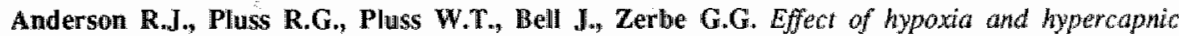
acidosis on renal autoregulation in the dog: renal nerves. Clin Sci 1983: 65: 533-538.

Anthonissen N.R., Wright E.C., Hodgkin J.E., IPPB Trial Group. Prognosis in chrontic obsiructive. pulmonary disease. Am Rev Respir Dis 1986; 133: 14-20.

Ashutosh K., Dunsky M. Noninvasive tests for responsiveness of pulmonary hypertension to axygen. Prediction of survival in patiens with chronic obstructive lung disease and cor pwimonale. Chese 1.987 ; 92: 393-399.

Bardsley P.A., Howard P. Cor pulmonale and home oxygen therapy. Practitioner 1986; $230: 565-571$.

Barer G.R., Pallot D.J. Changes in catecholamine content of the rat carovid body in chronic hypoxila and hypercapnia and its modification by carotid body sympathectomy. J Physiol 1986; 378:69p.

Becker C.G., Hajjar D.P., Hefton J.M. Tobacco constiuents are mitogenic for arterial smooth muscle cellis. Am J Pathol 1985; 120: 1-5.

Bergovsky E.H. Tissue oxygen delivery and cor pulmonale in chronic obstructive pulmomary disease. N Engl J Med 1983; 308; 1092-1094.

Dertoli L., Fusco M., Lo Cicero S., Micallef E., Busnardo I. Infuence of ACE inkibition on pulmonary haemodynamics and funcrion in patients in whom beta-blockers are contraindicated. Postgrad Med J 1986; 62 (suppl 1): 47-51. 


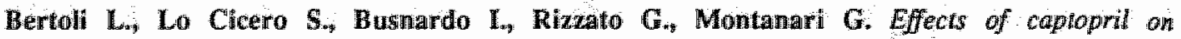
hemodynamics and blood gasses in chronic obstructive lung diseases with pulmomary hypertension. Respiration 1986; 49: 251-256.

Biernacki W. Flenley D.C., Muir A.L. et al. Pulmonary hypertensionand right ventricular function in pavienis with COPD. Chest 1988; 94: 1169-1175.

Biernacki W., Whyte K.F., Gould G.A., Belloni A., Flenley D.C. The extent of pulmonary emphysemat as assessed non-inuasively by $C T$ scan in life does not relate to pulmonary haemodynamics during rest or exercise. (Abstract) Thorax 1986; 41: 276.

Bihari $\mathrm{D}_{\text {, }}$ Smithies M., Gimson A, Tinker $\mathrm{J}$. The effects of vasodilation wirh prostacycline on axygen delivery and uptake in severely ill patienis. N Engl I Med 1987; 317: 397-403.

Birkenhäger W.H., de Leeuw P.W. Renal pathophysiology in essemtial hyperiension. Ipn Circ J 1987: 9: 61-72.

Bishop J.M., Csukas M. Combined use of non-invasive techniques to predict pulmonary artery pressure. in chronic respiratory disease. Thorax 1989; 44: 85-96.

Bishop J.M., Gross K.W. Use of ather physiologic variables to predict pulmonary artery pressure in patients with chronic respiratory disease. Eur Heart J 1981; 2: 509-517.

Borkenstein J. Foll of arterial $\mathrm{pO}_{2}$ under therapy with captopril in secondary pulmonary hypertension and right heart failure. Wiener Med Wochensch 1987; 137: 332-334.

Borst J.G.G. and Borts-de Geus A. Hypertension explained by Starling's theory of circulatory homeastasis. Lancet 1963; i: 677.

Bratel T., Hedenstierna G., Nyquist O., Ripe E. Long term treatment with a new calcium antagonist, felodipine, in chronic obstructive lung disease. Eur I Respir Dis 1986; 68: 351-361.

Breivik H., Grenvik A., Millen E., Safar P. Normalizing low arierial $\mathrm{CO}_{2}$ tension during mechanical ventilation. Chest $1973 ; 63$; 525-531.

Brent B.N.y Mattlay R.A., Mahler D.A., Berger H.J., Zaret B.L., Lister G. Relationship between axygen upvake and oxygen transport in stable patients with chronic obstructive pulmonary disease. Am Rov Respir Dis 1984; 129: 682-686.

Brown S.E., Pakron F.J. Milne N. et al. Effects of digaxin an exercise capacity and right ventricular function daring exercise in chronic airflow obstruction. Chest 1984; 85: 187-191.

Burach B., Pollack C., Borowlecki B., Weitzman E. The hypersomnia sleep apnoea-syndrome: a reversible major cardiovascular hazard. Circulation 1977; 56: 177.

30 Burke C.M., Horte M., Duncan J., Conally H.M., Morgan J.H. Captopril and donticiliary axygen in chronic airflow obstruction. Br Med J 1985; 290: 1251-1252.

31 Burnett J.C., Knox F.G. Renal interstitial pressure and sodium excretion during renal vein conssriction. Am J Physiol 1980; 238: 279-282.

32 Capewell S., Tavermer D., Hannan W.J., Muir A.L. Acute and chromic arterial and wenous effects of capropril in congestive heart failure. Br Med J 1989; 299: 942-945. 
Chappell T.R., Rubin LJ, Marklam R.V., Firth B.G. Independence of oxygen conzumption and systemic oxygen transport in patients with either stable pulmonary hypertension or refractory left ventricular failure. Am Rev Respir Dis 1983; 128: 30-33.

Chetty K.G., Brown S.E., Light R.W. Improved exercise tolerance of the polycythaemic lung parient following flebotomie. Am J Med 1983; 74: 415-420.

Chick T.W., Kochysosky K.N., Matsumato S. et al. The effect of nitroglycerine on gas exchange. haemodynamics and oxygen transport in patients with chronic obsiructive pulmontary disease. Am J Med Sci 1978; 276: 105-111.

Clark R.W., Boudoulas H., Schaal S.F., Schmidt H.S. Adrenergic hyperactivity and cardiac abnormality in primary disorder of sleep. Neurology 1980; 30: 113-119.

Cohn J.N., Archibald D.G., Phil M. et al. Effect of vasodilator therapy on mortality in chronic congestive heart failure. Results of a veterans administration cooperation study. N Engl J Med 1986; 1547-1552.

Cohn JNN. Relationship of plasma wolume changes to resistance and capacitance vessel effects of sympathomimetic amines and angiotensin in men. Clin Sci 1966; 30: 267-278.

Colice G.L. Fluid balance in acule and chronic lung disease. Am Rev Respir Dis 1988; 138: 10521053.

Consensus Trial Study Group. Effects of enalapril on mortality in severe congestive heart failure: results of the Caoperative North Scandinavian Enalapril Survival Study. N Engl J Med 1987; 316: 1429. 1435.

Cooper B.J., Waterhouse J., Howard P. Twelve year clinical sudy of patients with hypoxic cor pulmonale given long term damiciliary oxygen therapy. Thorax 1987; 42: 105-110.

Corriveau M.L., Rosen B.J., Dolan G.F. Oxygen transport and axgen consumption during supplemental oxygen administration in patients with chronic obstructive pulmonary disease. Am J Med 1989; 87: 633-637.

Cox D.R. Regression models and life-tables. J R Stat Soc [B] 1972; 34: 187-220.

Crozier I.G., Teok R., Kay R., Nichols G. Sympathetic nerwous system during converting enzyme inhibition. Am J Med 1989; 87 (suppl 6B): 29-32.

Cruickshank J.M., Thorp J.M., Zacharias F.J. Benefits and potential harm of lowering high blood pressure. Lancet 1987 ; i: $518-584$.

Dal Nogare A.R., Rubin L.J. The effects of hydralazine on excercise capacity in pulmonary hypertension secondary to chronic obstructive pulmonary disease. Am Rev Respir Dis 1986; 133: 385389.

Dantzker D.R., d'Alionzo G.E. The effect of exercise on pulmonary gas exchange in patients with severe chronic obstructive pulmonany disease. Am Rew Respir Dis 1986; 134: 1135-1139.

Degaute J.P., Domenighetti G., Naeye R. et all. Oxygen delivery in actue exacerbation of chronic obstrucive pulmonary disease: effects of controlled oxygen therapy. Am Rev Respir Dis 1981; 124: 2630. 
Denolin H. Clinical rials with long-term treatment of pulmonary hypertension due to lung disease. Eur Heart J 1988: 9 (suppl J): 29.32.

Dhillon D.P., Barer G.R., Wallsh M. The enlarged carotid body of the chronically hypoxic and hypercapnic rats a morphometric analysis. Q J Exp Physiol 1984, 64: 301-317.

Diener C.F., Burrows B. Further abservations on the course and prognosis of chronic obstructive lung. disease. Am Rev Respir Dis 1975; 11: 719-724.

Dinh-Xuan A.T., Higenbottam T.W., Clelland C.A. et al. Impairment of endothelium-dependent pulmonary-artery relaration in chronic obstructive lung disease. N Engl J Med 1991; 324: 1539-1547.

Doorenbos C.J. Atrial natrituretic peptide. Neth J Med 1991; 39: 28-44.

Drayer J.IM., Benraad Thal. The reliability of the measurement of plasma renin activity by radia immuno exsay. Clin Chim Act 1975; 61: 309-324.

Dzau V J. Circulating versus local renin-angiotensin system in cardiovascular systems. Circulation 1988; 77 (suppl 1): 11.4-1.13.

Epstein M. Renal effects of head out immersion in man: implications for an understanding of wolume homeostasis. Physiol Rew 1978: 58: 529-585.

von Euler U.S., Liljestrand G. Observations on the pulmonary arterial blood pressure in the cat. Acta Physiol Scand 1946; 12:301-320.

Fagard R., Lijnen P., Staessen $\mathbf{J}_{\text {., }}$ Verschuere J., Amery A. The pulmonary circulation in essential systemic hypertension. Am J Cardiol 1988; 61: 1061-1065.

Farber M.O., Manfredi F. Mechanisms of hyponatremia and edema in chronic obstructive pulmonary disease: clinical significance. Pract Cardiol 1984; 10: 105-131.

Farber M.O., Roberts L.R., Weinberger M.H., Robertson G.L., Fineberg N.S., Manfredi F. Abnormalities of sodium and water handling in chronic obstructive lung disease. Arch Int Med 1982; 142: $1326 \times 1330$.

Ferguson D.W., Hayes D.W. Nifedipine potentiates cardiopulmonary baroreflex control of sympathetic nerve activity in healthy humans. Circulation 1989; 80: 285-298.

Firth J.D., Ledingham J.G.G., Raine A.E.G. Raised venous pressure: a direct cause of renal sodium retention in oedema? Lancet 1988; i: 1033-1035.

Fishman A.P. Chronic cor pulmonale. Am Rev Respir Dis 1976; 114: 775-794.

Fishman A.P., Maxwell M.H., Crowder C.H., Morales P. Kidney function in cor pulmonale. Particular consideration of changes in renal hemodynamics and sodium excretion during wariation in level of oxygenation. Circulation 1951; 3: 703-721.

Fletcher E.C., de Behnke R.D., Lovoi M.S., Gorin A.IB. Undiagnosed sleep apnoed in patients with essenial hypertension. Ann Ini Med 1985; 103: 190-195.

Fletcher E.C., Luckett R.A., Miller T., Fletcher J.G. Exercise hemodynamics and gas exchange in patients with chronic obstructive pulmonary disease, sleep desaturation and a daytime $\mathrm{PaO}_{2}$ above 60 mm/1g. Am Rev Respir Dis 1989; 140: 1237-1245. 
Fletcher E.C., Miller J, Divine G. W., Fletcher J.G., Miller T. Nochurnal oxphemoglobin desaturation in COPD patients wish arterial oxygen tensions above 60 mmHg. Chest 1987: 92: 604-608.

Fletcher E.C., Miller J., Schaaf J.W., Fletcher J.G. Urimary catecholamines before and after tracheostomy in patiens with obstructive sieep apnoea and hypertension. Sleep 1987, 10: 35-44.

Folkow B., di Bona G.F., Hjemdahl P., Tharen P.H., Wallin B.G. Measurements of plasma norepinephrine concentrations in human primary hypertension: a word of caution on their applicability for assessing newrogenic contributions. Hypertension 1983; 5: 399-403.

France A.J., Prescott R.J., Biernacki W., Muir A.L., MacNee W. Daes righ ventricular function predict survival in patients with chronic obstructive lung disease? Thorax 1988; 43:621-626.

Frohlich E.D., Iwata T., Sasaki O. Clinical and physiological significance of local tissue renimangiotensin systems. Am J Med 1989; 87 (suppl 6B): 19-23.

Gaillard C.A., Koomans H.A., Dorhout Mees E.J. Enalapril attenuates natriuresis of atrial natriurevic factor in humans. Hypertension 1988; 11: 160-165.

Gans R.O.B., Hoorntje S.J., Donker A.J.M. Renal effects of angiotensin, converting enzyme inhibitors. Neth J Med 1988; 32: 247-264.

Gimeno Ortega F. Langdurige zusurstoftoediening mer zuurstof thuis. Ned Tijdschr Geneesk 1986; 130 : 253-255.

Grant B.J.B., Futzpatrick J.M., Lieber B.B. Time-varying pulmonary arterial compliance. J Appl Physiol 1991; 70: 575-583.

Green L.H., Smith T.W. The use of digitalis in patients with pulmonary disease. Ann Int Med 1977; 87: $459-465$.

Guilleminault C., Simmons F.B., Motta J. et al. Obstructive sleep apnea syndrane and tracheostonny. Arch Int Med 1981; 141: 985-988.

Guyton A.C. Lindsay A.W., Abernathy B., Richardson T. Vevons return at variows righ arriol pressures and the normat venous return curve. Am J Physiol 1957; 189: 609-615.

Hambley H., Mufti G.J. Erythropoietin: an old friend revisited. Br Med 1990; 300: 621-622.

Harvey R.M., Euson Y., Betti R., Lewis M.L., Rochester D.F., Ferrer M.I. Further abservations on the effect of hydrogen ion on the pulmonary circulation. Circulation 1967; 35: 1019-1027.

Heath D., Williams D.R. Pumomary hypertension. In: Man at high altitude. $2^{\text {ud }}$ edn. Edinburgh: Churchill Livingstone $1981 ; 103$.

Hedemark L.L., Kromenberg R.S. Ventilatory and heart rate responses to hypoxia and hypercapmia during sleep in adalss. I Appl Physiol 1982; 53: 307-312. 
Heistad D.D. Kontos H.A. Cerebral circulation. In: Berne R.M. (ed). The cardiovascular system, wol. III. Shepperd IT, Abboud FM. (ed). Peripheral circulation and organ blood flow, part I. Baltimore: Willams o Wilkins 1983 "137-182,

Hendriksen J.H., Christensen $\mathrm{N}$ I., Kolk-Jensen A, Christiansen I. Increased plasma moradrenaline concentration in patiens with chronic obstructive lung disease: relation to haemodynamics and blood gasses. Sicand I Clin Lab Invest 1980; 40:419-427.

Hicken P.D., Heath $\mathrm{D}_{\text {, }}$ Brewer B., Whitaker W. The small anteries in emphysema. I Pathol Bact 1968; $90: 107-115$.

Himelman R.B, Struve S.N., Brown J.K., Namnum P., Schiller N.B. Improved recognition of car pulmonale in patients with severe chronic obstractive pulmonary disecase. Am J Med 1988; 84: 891-898.

Hirchkowitx M., Karacan I., Gurakar A., Williams R.L. Hypertension, erecrile dysfunction and occult sleep apnoea. Sleep 1989; 12: 223-232.

Hulks G., Jardine A., Connell J.M.C., Thompson N.C. Bronchodilator effect of arrial matriuretic peptide in asthma. Br Med J 1989; 299: 1081-1082. response to axygen therapy in hypoxaemic chronic aiflow absiruction. Thorax 1989; 44: 930-936.

Hurewitx A.N., Bergovsky E.H. The therapy of cor pulmonale. Curr Pulmonol 1988; 9: 395-416.

Hurford W.E., Zapol W.M. The right wentricle and critical illmess: a review of anatomy, physiology and clinical evaluation of its function. Int Care Med 1988; 14 (suppli 2): 448-457.

Huval W.V., Mathieson M.A., Stemp L.I. et al. Therapeutic benefits of 5 -hydroxytryptamine inhibition following pulmonary embolism. Ann Surg 1983; 197: 220-225.

Huysmans F.T.M., Thien Th.A. Vaavenwijders voor de behandeling van hypertensie. Ned Tijdschr Geneesk 1989; 133: 595-599.

Hyman A., Nandiwanta P., Knight D., Kadowiz P. Pulmonary wascular response to catecholamine and syfemic nerve stimulation in the cat - evidence that the vascular $\beta-2$-adrenoreceprors are innervated. Circ Red 1981; 48: 407-515.

Isbister J.P. Haevatological and rheological aspects of oxygen transport: the optional hematocrit. In: Vincent J.L. (ed) Update in intensive care and emergency medicine. Springer-Verlag, Berlin-HeidelbergNew York 1990; 224-239.

Jamal K., Fleetham J.A., Thurlbeck W.M. Cor pulmonale: Correlation with central ainways lesions. peripheral airway lesions, emphysema, and control of breathing. Am Rev Respir Dis 1990; 141: 1172 1177.

Johnson D.C.* Joshi R.C., Mekta R., Cunnington A.R. Acule and long term effect of mifedipine on pulmonary hypertension secondary to chronic obstructive airways disease. Eur J Respir Dis 1986; 69 (suppl 146): 495-502.

Johnson R.A., Rubin L.J. Noninvasive evaluation of right ventricular function. Clin Chest Med 1987; 8: $65-80$. 
Johnston M.B., Hodsman P.G., Kohzumi M., Casley DJ., Fabris B, Phillips P.A. Interacton between atrial natriuretic peptide and the renin angiotensin aldosterone system Am J Med 1989:87 (suppl 6B): 24-28.

Kahler R.L., Goldblatt A., Braunwald E. Effects of acute hypoxia on the systemic venous and arterial systems and on myacardial contracile force. J Clin Invest 1962; 41: 1553-1563:

Kalra L., Bone M.F. Niffedipine and impaired oxygenation in patients with chronuc bronchits and cor pulmonale. Lancet 1989; i: 1135-1136.

Kannell W.B., Gordon T., Wolf P.A. et al. Haemoglobin and the rist of cerebral inforction. The Framingham Study. Stroke 1972; 3: 409-420.

Kaplan E.L., Meier P. Nomparametric estimation from incomplete observations. J Am Stat Assoc 1958; 53: $457-481$.

Kasahara Y, Ashihara Y. Colorimetry of angiotensine I converting enzyme activity in serum. Clin Chem 1981: 27: 1922-1925.

Kawakami Y., Kishi F, Yamamoto H., Miyamoto K. Relation of oxygen delivery mixed vesous oxygenation and pulmonary hemodynamics to prognosis in chronic obstructive pulmonary disease. $\mathrm{N}$ Engl J Med 1983; 308: 1045-1049.

Keller C.A., Shepard Jr J.W., Chun C.S., Vasquez P., Dolan G.F. Pulmonary wpertension in chronic obstructive pulmonary disease. Multivariate analysis. Chest 1986; 90: 185-192.

109 Kennedy T.P., Michael J.R., Huang C.K. et al. Nifedipine inhibits hypoxic pulmanary vasoconstriction during rest and exercise in patients with chronic obstructive pulmonary disease. Am Rev Respir Dis 1984; 129: 544-551.

110 Khaja F.U., Parker J.D. Right en left ventricular performance in chronic obstrucaive lung disease. Am Heart I 1971; 82: 319-327.

111 Kim Y.S., Aviado D.M. Digitalis and the pulmonary circulation. Am Heart J 1961; 62: 680-686.

112 Klinger J.R., Hill N.S. Right wentricular dysfunction in chronic obstructive pulmonary disease. Evaluation and management. Chest 1991; 99: 715-723.

113 Lameire N.H., Matthys E., Kesteloot D., Waterloos M-A. Effect of serotomin blocking agent on renal hemodynamics in the normal rat. Kidney Imt 1990; 38: 823-829.

114 Lanigan C., Moxhan J, Ponte J. Effecr of chronic airflow limitation on resting oxygen consumption. Thorax 1990; 45: 388-390.

115 Laragh J.H. Atrial natriuretic harmone, the renin-aldosterone axis and bloot pressure electrolyte homeostasis. N Engl J Med 1985: 313: 1330-1340.

116 Laragh J.H. Plasma renin as a risk factor for hear auack and stroke in hypertension. Procedings "Second international symposium on ACE inhibition, Londom, 1991.

117 de Leeuw P.W., Birkenhäger W.H. Renal blood flow in essential hypertension. I Cardiovasc Plarmacol 1987; 10 (suppl 5): 510-513. 
118 de Leew P.W, Kho Th, Falke H.E, Birkenháger W.H., Wester A. Haemodynamic and endocrimological profile of essential hyperiension. Act Med Scand 1978. (suppl 622): 17-34.

119 de Leww P. Vasoregulation and renal function in essential hypertension. Rotterdam, Thesis 1978.

120 Liu F.Y, Cogan M.G. Angiotensine II: a potent regulator of acidification in the rat early proximal convoluted watbule. J Clin Invest 1987; 80:272.

121 Lockhart A., Pham Q.T., Nakache J.P., Salmon D., Perrault J. Pression arterielle pulmonaire dans la bronchite bien compensée: étude par l'analyse factorielle des correspondances. Bull Physiopathol Respir 1969: 5: 347.361 .

Loffahl C-C. Antihypertensive drugs and airway function, with special reference to calcium channel blockade. J Cardiovase Pharmacol 1989; 14 (suppl 10): S40-S51.

Logan M.G., Alpern R.Jl. Regulation of proximal bicarbonate reabsorption. Am J Physiol 1984; 247 : F387.

124 Lund-Johansen P., White W.B. Central hemodynamics and 24-hour blood pressure in obstructive sleep apnea syndrame: effects of surgery. Am J Med 1990; 88: 678-682.

125 Lupi-Herrera $\mathbf{E}$, Seoane M., Verdejo J. Haemadymamic effect of hydralazine in advanced stable chronic obstructive pulmonary disease with cor pulmonale. Chest 1984; 85: 156-163.

126 Mackenzie J.D., Haites N.E., Rawles J.M. Method of assessing the reproducability of blood flow measurement: factors influencing the performance of thermodilution cardiac output computers. Br Heart J 1986: $55: 14-24$.

127 MacNee W., Wathen C.G., Flenley D.C., Muir A.L. The effects of controlled oxygen therapy on ventricular function in patients with stable and decompensated cor pulmonale. Am Rev Respir Dis 1988; 137: $1289-1295$.

128 Magee F, Wright J.L., Wiggs B.R., Paré P.D., Hogg J.C. Putmonary vascular structure and function in chronic obstructive pulmonary disease. Thorax 1988; 43: 183-189.

129. Mahler D.A., Brent B.N., Loke J. et al. Right wentricular performance and central circulatory hemodynanics during uprigh exercise in patients with chronic abstructive putmonary disease. Am Rev Respir Dis 1986; 130: 722-729.

130 Malik A.B., Kidd B.S.L. Independemt effects of changes in $\mathrm{H}^{*}$ and $\mathrm{CO}_{2}$ concentrations on hypoxic pulmonary wasoconstriction. J Appl Physiol 1973; 34: 318-323.

131 Mannix E.T, Dowdeswell I., Carlone S., Palange P., Aronoff G.R., Farber M.O. The effect of oxygen an sodium excretion in hypoxemic patients with chronic obstructive lung disease. Chest 1990; 97: 840-844.

132 Marchandise B. Non-invasive prediction of pulmonary hypertension in chronic abstructive pulmonary disease by Doppler echocardiography. Chest 1987; 91: 361-365.

133 Matthay R.A., Bergen H.J. Cardiovascular function in cor pulmonale. Clin Chest Med 1983; 4: 269295. 
Matthay R.A., Niederman M.S., Wiedemann H.P. Cardionascular-pumonary interacion in chronic abstructive pulmonary disease with special reference to the pathogenesis and management of cor pulmonale. Med Clin North Am 1990; 74: 571-618.

Matthay R.A., Schwarz MI., Ellis J.H, et al. Pulmonary artery hypertension in chronic obstructive pulmonary disease: determination by chest radiography. Invest Radiol 1981; 16: $95-100$.

Matthews A.W., Peacock A.J. The effect of captopril on pulmanary haemodynamics, angionensin II and plasma renin in patients with chronic airflow obstruction. Proceedings Symposium Pulmonary Circulation V, Prague 1989.

McAllister R.G. Kinetics and dynamics of nifedipine after oral and sublingual doses. Am J Med 1986; 81 (suppl 6A): 2-5.

McGregor M., Sniderman A. On pultmonary vascular resistamce: the need for more precise definition. Am J Cardiol 1985; 55: 217-221.

Medical Research Council Working Party. Long term domiciliary oxygen therapy in chronic hypoxic cor pulmonale complicating bronchitis and emphysema. Lancet 1981; i: $681-686$.

Melot C., Hallemans R., Naeye R., Mols P., Lejeune P. Deleterious effect of nifedipine on pulmonary gas exchange in chronic abstructive pulmonary disease. Am Rev Respir Dis 1984; 130: 612-616.

Meurice J.C., Boutaud P., Herpin D. et al. Valke of nifedipine in respiratory failure related to obstructive chronic bronchitis during treatment over 6 manths. Ann Cardiol Angeiol 1989; 38: 171-177.

Miller P.D., Berns A.S. Acute metabolic alkalosis perpeituating hypercapnia: A role for acetazolanide in chronic obstructive pulmonary disease J Am Med Assoc 1977; 238: 2400.

Mithoefer J.C., Holfard F.D., Keigbley J.F.H. The effect of oxygen administration on mixed venous axygenation in chronic obstructive pulmonary disease. Chest 1974; 66: 122-131.

Mols P., Naeye R., Hallemans R., Melot $\mathbf{C}_{\text {, }}$ Lejeune $\mathbf{P}$., Englert $\mathbf{M}$. Central and regional hemodynamic effects of nitrendipine in normotensive patients with chronic obstructive lung discase. I Cardiovase Pharmacol 1986: 8: 77-81.

Morrison D.A., Goldman S., Wright A.L. et al. The effect of pulmonary hypertension on sysiolic function of the right verturicle. Chest 1983; 84: 250-257.

147 Morrison D.A. Pulmonary hypertension in chronic obstructive pulmonary disedse; the right ventricular hypotheris. Chest 1987; 92: 387-389.

148 Neidhart P.P., Suter P.M. Changes of right verutricular function with positive end-expiratory pressure (PEEP) in man. Int Care Med 1988; 14: 471 473.

Ng K.K.F., Vane J.R. Conversion of angiotensin I to angiotensin II. Nature 1967; 216: 762.

Nocturnal Oxygen Therapy Trial Group. Conimuous or nocturnal oxygen therapy in hypoxemic chronic obstructive lung disease: a clinical trial. Ann Int Med 1980; 93: 391-398. 
152 Oliwer R.M., Peacock AJ., Fleming J.S., Waller D.G. Renal and pulmonary effects of angiotensine converting enzyme inhibition in chronic hypoxic lung disease. Thorax 1989; 44: 513-515.

153 Ostadal B., Ressl J., Urbanowa D. et al. The effect of beta adrenergic blockade on pulmonary hypertension, wigh wentricular hypertrophy and polycythaemia induced in rats by high altitude hypoxia. Basic Res Cardiol 1978; 732:322-389.

154 Oswald M, Apprill M., Mirhom R., Ehrhart $M_{*}$. Weitzenblum E. Pulmonary hemodynamics in "pure" emphysema. Proceedings Symposium Pulmonary Circulation V, Prague 1989.

155 Packer M. Conwerting enzyme inhibition for severe chronic heart failure: views from a skeptic. Int J Cardiol 1985; $7: 111-120$.

156 Patakas D., Georgopoulos D., Rodini H., Christaki P. Effects of captopril in patients with chronic obstructive pulmonary disease and secondary pulmonary hypertension. Postgrad Med J 1988; 64: 193. 195.

157 Peacock AuJ. Pulmonary hypertension due to chronic hypoxia: Br Med J 1990; 300; 763-764.

158 Peto R., Speizer F.E., Cochrane A.L. et al. The relevance in adults of airflow obstruction, but not of mucus hypersecretion, to mortality from chronic lang disease. Am Rev Respir Dis 1983; $128: 491.500$.

159 Petty T.L. Home oxygen - a revolution in the care of advanced COPD. Med Clin North Am 1990; 74: $715-740$.

160 Peuler J. Johnson G.A. Simultaneous single isotope radioenzymatic assay of plasma norepinephrine, epinephrine and dopamine. Life Sci 1977; 21: 625-631.

161 Platell C., Hall J., Dobb G. Impaired renal function due to raised intraabdominal pressure. Int Care Med 1990; 16: 328-329.

162 Porcelli R.J., Bergovsky E.H. Adrenergic receptors in pulmonary vasaconstrictor responses to gaseous and kiumoral agents. J Appl Physiol 1973; 34: 483-487.

163 Postma D.S., Burema J., Gümeno Ortega F. et al. Prognosis in severe chronic obstructive pulmonary disease. Am Rev Respir Dis 1979; 11: 357-367.

164 Postma D.S. Koëter G.H., Sluiter H.J. Behandeling van patienten met longemphyseem. Airways 1985; 4: 311.

165 Price H.L. Effects of carbondioxide on the cardiovascular system. Anesthesiology 1960; 21: 652-653.

166 Rabinovitch M.s, Gamba W., Nadas A.S., Miettinen O.S., Reïd L. Rat pulmonary circulation after chronic hypoxia: hemodynamic and struccural features. Am J Physiol 1979; 236: 818-826.

167 Raff H., Levy S.A. Renine - Angiotensine II - Aldosterone and ACTH-cortisol control during acute hypoxemia and exercise in potients with chronic abstructive pulmonary disease. Am Rev Respir Dis 1986; 133: 396-399.

168 Raine A.E.G., Erne P. Bürgisser E. et al. Atrial natriuretic pepride and atrial pressure in patients with congestive heart failwe. N Engl J Med 1986; 315: 533-537.

169 Read J., Lee J. Regional pulmonary vasoconstriction as in individual factor with gemesis of cor pulmonale. Am Rev Respir Dis 1967; 96: 1181. 
Reid L. Structure and function in pulmonary hypertension - new perceptions. Chest 1986, 89:279-288.

Reilhman D.H., Farber M.O., Weinberger M.H. et al. Effect of hypoxemia on sodium and water excretion in chronic obstructive lung disease. Am J Med 1985; 78: 87-94.

Renzetti A.D., McClement J.H., Litt B.D. The veterans administration cooperative study of pulmonary function. Am J Med 1966; 41: 115-129.

Ringsted C.V., Eliasen R., Andersen J.B., Heslet L., Quist J. Ventilation perfusion distributions and" central hemotynamics in chronic obstructive pulmonary disease. Chest 1990; 96: 976-983.

Rizzato G., Rampulla C., Mandelli V., Benza G.C., Mantero O,, Morpugo M. Can pulmonary artery pressure be predicted without right heart catheterisation in chronic obstmuctive lung disease? Acta Cardiol 1975; 30: 251-265.

Robin E. The cult of the Swan-Ganz carheter. Ann Int Med 1985; 103: 445-449.

Rose B.D. Clinical Physialogy of acid-base and electralyte disturbances. 3rd ed McGraw-Hill, Singapore $1989 ; 442$.

Rounds S., Hill N.S. Pulmonary hypertensive diseases. Chest 1984; 85: 397-405.

Rubin L.J., Moser K.M. Long term effects of nitrendipine on hemodymamics and oxygen transport in patients with cor pulmanale. Chest 1986; 89: 141-145.

Rubin LJ. Vasodilators and pulmonary hypertension: where do we go from here? Am Rev Respir Dis 1987; 135: 287 .

Schmidt H.H.W., Schurr C., Hedler $L_{\text {." }}$ et al. Local modulation of noradrenaline release in vivo: presynaptic $\beta_{2}$-adrenoceptors and endogenous adrenaline. J Cardiovasc. Pharmacol 1984; 6: 641-649.

Schrier R.W.Pathogenesis of sodium and water retention in high-outpu and low-oulput cardiac failure nephratic syndrome, cirrhosis and pregnancy. N Engl J Med 1988; 319: 1065-1071.

Schrijen $F_{\text {, }}$ Redondo J., Henrigues A., Polu J.M. Right ventricular ejection fraction and volimes at rest and during low load exercise in chronic lung disease patients with and without past right heart failure. Proceedings Symposium Pulmonary Circulation V. Prague 1989.

Selinger S.R., Kennedy T.P., Buescher P. et al. Effecrs of removing oxygen from pathents with chronic. obstructive pulmonary disease. Am Rev Respir Dis 1987; 137: 85-91.

S4. Semple P.F. Cough and wheeze caused by imhibitors of angiotensine converting enzyme. N Engl J Med 1986: 314: 61,

Sharkey S.W. Beyond the wedge. clinical physiology and the Swan-Ganz catheter. An I Med 1987: 83: $111-122$.

Shoemaker W.C., Appel P.L., Kram H.B. Measurement of tissue perfision by axygen transport paterns in experimental shock and in high risk surgical potients. Int Care Med 1990; 16 (suppl 2): S135-S144.

Siedelin P.H. Coutie W., Struthers A.D. The effect of angiatensin I/ on noradrenaline release in man. Br I Clin Pharmacol 1987; 24:261. 

by nifedipine. N Engl I Med 1981; 304: 1582-1585.

Singh $\mathrm{H}_{.,}$Ebejer M.J, Higgins D.A., Henderson A.H, Campbell 1.A. Acute hemodynamic effects of nifedipine at rest and during maximal exercise in patients with chronic cor pulmanale. Tharax $1985^{;} 40$ : 910-914.

Skinner S.L., Cran E.J.s Gibson R., Taylor R., Walters W.A.W, Catt K.J. Angiotensin and $_{y \rightarrow}$ active and inactive renin, reninsubstrate, renin activity and angiotensinase in human liquar amnit and plasma. Am J Obstet Gynecol 1975; 121: 626-630.

Skorecki K.L., Brenner B.M. Body fluid homeostasis in congestive heart failure and cirrhosis with ascites. Am I Med 1982; 72: 323-338.

Skwarskii K., Sankaran R., Biernacki W., Flenley D.C., Lee M.R.y MacNee W. Atrial natriuretic peptide (ANP) in patients with acute exacerbations and clinically stable chronic obstructive pulmonary disease (COPD). Proceedings "Pulmonary Curculation W', Prague 1989.

the SOLVD Investigators. Effect of captopril on survival in patients with reduced left venuricular ejection froctions and congestive heart failure. $\mathrm{N}$ Engl J Med 1991; 325: 293-302.

Somers V.K., Mark A.L., Abboud F.M. Sympathetic activation by hypaxia and hypercapriaimplications for sleep apnoea. Clin Exp Hypertens 1988; 10 (suppl 1): 413-422.

Sparrow D., Weiss S.T., Vokonas P.T., Cupples L.A., Ekerdt D.J., Colton T. Forced vilal capaciny and the risk of hypertension. Am J Epidemiol 1988; 127: 734-741.

Staessen J. Mortality and treated blood pressure in patients of the European Working Party on High Blood Pressure in the elderly. Am J Med 1991; 90 (suppl 3A): 605-635.

Starre P.J. van der" Ketanserin and hypertension in cardiac surgery. Thesis, Maastricht 1988.

Staub $\mathbb{N}_{*}$ Site of hypoxic pulmanary vasoconstriction. Chest $1985 ; 88: 240-245$.

Steelle P., Ellis J.H., van Dijke D. et al. Left wentricular ejection fraction in severe chronic obstructive airways disease. Am I Med 1975; 59:21-28.

200 Stewart A.G., Bardsley P.A., Baudouin et al. Chonges in arial nariuretic peptide concentrations during intravenows saline infusion in hypoxic cor pulmonale. Thorax 1991; 46: 829-834.

Stradling J.R. Sleep apnea and systemic typertension. Thorax 1989; 44: 984-989.

Sturani C., Bassein L., Schiavina M., Gunella G. Oral nifedipine in chronic car pulmonale secondary to severe chronic obstructive pulmonary disease (COPD). Shorf-and longwerm hemodynamic effects. Chest 1983; 84: 135-142.

Suki W.N. Renal hemodynamic consequences of angiotensine converning enzyme intibition in congestive heart foilure. Arch Int Med 1989; 149: 669-673.

Timms R.M., Khaja F.U., Williams G.W. Hemodynamic response to axygen therapy in chronic obstructive pulmonary disease. Ann In Med 1985; 102: 29-36.

Traver G.A., Cline M.G., Burrows B. Predictors of mortality in chronic obstructive pulmonary disease. A 15-year follow-np study. Am Rev Respir Dis 1979. 119: 895-902. 
Trzebski A, Tafil M., Zoltowski M., Praybylskî. I. Increased sensitivity of the arterial chemoreceptor drive in young men with mild hypertension. Cardiowasc Res 1982; 16: 163-172

Vane J.R., Änggård E.E., Botting R.M. Regulatory functions of the vascular endothelium. N Engl J Med 1990; 323: 27-36.

Vanhoutte P.M. Serotonin, hypertension and wascullar disease. Neth J Med 1991; 38: 35-42.

Vanhoutte P.M. The endothelium - modulator of wascular smooth muscle tone. N Engl J Med 1988; 319: 512-513.

Vermey C.G., Feenstra B.W.A., Bruining H.A. Is bij ermbrig zieke patiēnten de opname van zuurstof afhankelijk wan hiet zuurstofaanbod? Int Care Rew 1990; 5: 141-146.

Vestri R., Philip-Joët F., Surpas P., Arnaud A., Saadjian A. One year clinical study of mifedipine in the treatment op pulmonary hypertemsion in chronic obstructive lung disease. Respiration 1988; 54 : 139 144 .

212 Vïtanen A., Salmenperä M., Heinonen J., Hynynen M. Pulmonary vascular resistance befare and after cardiopulntomary bypass. Chest 1989; 95: 773-778.

Vik-Mo H., Halvorsen F.J., Thorsen E., Walde N.H., Rosland G.A. Improved cardiac performance by salbulamol, a selective $\beta_{2}$-agonist, in chronic cor pulmonale. J Cardiovasc Pharmacol 1987; 9: 129134.

214 Vincent J.L. The relation between oxygen demand, oxygen uptake, and oxygen supply. Int Care Med 1990; 16 (suppl 2): S145-S 148 .

Voelkel N.F. Mechanisms of hypoxic pulmonary vasoconstriction. Am Rew Respir Dis 1986; 133: 11861195.

Wagenaar S.J., Wagemwoort C.A. Experimental production of longtidudinal smooth muscle cell in the intima of musculair arteries. Lab Invest 1978; 39: 370-374.

Wallenstein S., Zucker C.L., Flleiss J.L. Some statistical methods useful in circulation research. Circ Res 1980; 47: 1-9.

Watsh D.A.y Gowan J.R. Long-term continuous domiciliarly oxygen therapie by transtracheal catheter. Thorax 1990; 45: 478-481.

Walsh P.R., Wang M.C., Turner E.A. Non-chromatographic radio immino essay procedure for urinary aldosterone. Clin Chem 1979; $25: 1226-1229$.

Wedzicha J.A., Rudd R.M., Apps M.C.P. et al. Eryropheresis in patients with polycythaemia secondary to hypoxic lung disease. Br Med J 1983; 286: 511 -514.

Weinberger S.E., Schwartastein R.M., Weiss J.W. Mypercapnia. N Engl J Med 1989; 321: 1223-1231.

Weisse A.B., Moschos C.B., Frank M.J. et all. Haemodynamic effects of staged haematocrit reducrion in patients with stable cor pulmonale and severely elevated haematocrit levels. Am J Med 1975; $58: 92$ 98.

Weitzenbllum E., Hirth C., Duculone A, Mirhom R., Rasaholinjanahary R., Ehrhart M. Prognostic value of pulmonary artery pressure in chronic obstructive pulmonary disease. Thorax 1981; 36: 752-758. 
224 Weltxenblum E, Sautegau A, Ehrhart M, Mammoser $M_{*}$ Pelletier A. Long-term oxygen therapy can reverse the progression of pulmonary hypertension in patients with chronic obstructive pulmonary disease. Am Rew Respir Dis 1985; 131; 493-498.

225 Weselcough E.O., Humphrey W.R., Aiken J.W. Effect of pumonary and renal circulations on activity of arial matriuretic peptide. Am I Physiol 1985; 249: R595-R602.

226 Westendorp R.J.G., Roos A.M., Meinders A.E. Atrial natriuretic peptide is a regulator of pulmonary vascular tone. A hypothesis. Nah J Med 1990; 37: 167-170.

227 Westerhof P.W., Mensing B.T.J. Pathofysiologische achtergronden en behandeling van decompensatio cordis. Ned Tijdschr Geneesk 1989; 133: 1206-1210.

228 Wetzels J.F.M., Huysmans, F.T.M., Koene R.A.P. Creatinine as a marker of glomerulair filitration rate. Neth J Med 1988; 33: 144-153.

229 Whyte K.F., Flenley D.C. Can pulmonary vasodilators improve survival in cor pulmonale due to hypoxic bronchitis and emphysema? Thorax 1988; 43: 1-8.

230 Widimsky J, Ostadal B., Urbanova D. et al. Intermittent high altitude hypoxia. Chest 1980; 77: 383. 389.

231 Wilkinson M., Langhorne C.A., Heath D., Barer G., Howard P. A pathophysiological study of 10 cases of hypoxic cor pulmonale. Quart J Med 1988; 66: 65-87.

232 Will D.H., Council M.A. Atriopeptingr: a pulmonary vasodilator in experimental hypoxic pulmonary hypertension. (Abstract) Fed Proc 1986; $45: 2341$.

233 Williams I.P., Boyd M.J., Humberstone A.M., Wilson A.G., Millard F.J.C. Pulmonary arterial hypertension and emphysema. Br J Dis Chest 1984; 78: 211-216.

234 Winter R.J.D., Davidson A.C., Treacher D et al. Alrial nariuretic peptide concentrations in hypoxic secondary pulmonary hypertension: relation to haemodynamic and bloodgas wariables and response to supplemental oxygen. Thorax 1989: 44: 58-62.

235 Wognum A.W., Lansdorp P.M., Eaves C.E, Krystal G. Use of a sensitive bioimunu absorbem: assay to bolate and characterize monoclonal antibodies to biologically active human erythropoietin. Blood 1988" 71: 1731-1737.

236 Zielinsky J., Hawrielkiewicz I., Górecka D., Gluskowski J., Koscinska M. Captopril effects an pulmonary and systemic hemodynamics in chronic cor pulmonale. Chest 1986; 90:562-565.

237 Zusman R.M. Revin and mon-renin mediated antihypertensive cotion of converting enzyme inhibitors. Kidncy Int 1984:25: 969-983. 


\section{Samenvatting}

Dit proefschrift richt zich op de mechanismen die kunnen leiden tot het cor pulmonale, secundair aan het chronisch obstructief longlijden. Naar aanleiding van literatuurgegevens over de invloed van chronische hypoxie op de rechter-ventrikelfunctie, is nader haemodynamisch-endocrien onderzoek verricht.

Hoofdstuk 1 reikt de bouwstenen aan van het klinisch verrichte onderzoek; de haemodynamiek (systemisch, pulmonaal en renaal) en de neuro-endocriene invloeden (sympathicus en Renine-Angiotensine-Aldosteron Systeem (RAAS)) worden bestudeerd. Conform de huidige inzichten, waarbij OZT als belangrijkste therapeuticum geldt, werden de onderzoekingen verricht tijdens normoxie.

Het gekozen model staat zo toe de invloeden van de $\mathrm{PaCO}_{2}$ op de circulatie vast te leggen. Bij de evaluatie van de gegevens wordt zoveel mogelijk getracht te werken met eenvoudige variabelen als de longfunctie, de gaswaarden en de gemiddelde bloeddruk.

Hoofdstuk 2 beschrijft de literatuurgegevens. Hypoxie en hypercapnie leiden niet alleen tot pulmonale vasoconstrictie, doch ook tot water- en zoutretentie via de nier. Studies bij het slaap-apneu-syndroom hebben geleerd dat hypertensie en cardiovasculaire complicaties frequent voorkomen, waarschijnlijk als gevolg van sympathicusstimulatie.

In de diagnostiek van de pulmonale hypertensie levert rechtscatheterisatie, hoewel niet zonder gevaren, de zuiverste gegevens op. Met betrekking tot de therapie speelt OZT de belangrijkste rol. In tegenstelling tot de situatie bij het linker-ventrikelfalen is de plaats van diuretica, digoxine en vaatverwijders in de therapie bescheiden, soms zelfs gevaarlijk.

Hoofdstuk 3 vat de gebruikte methoden samen en beschrijft de criteria voor de patiẻntenselectie.

Hoofdstuk 4 beschrijft de uitgangswaarden en hun onderlinge verbanden. Er blijken correlaties aanwezig te zijn die erop wijzen dat de longen (longfunctie, gaswaarden) verregaand de systemische en renale circulatie beinvloeden. Daarbij valt op dat de reninespiegels en de bicarbonaatwaarden hoog zijn, in aanmerking genomen de milde hypercapnie, de normale vullingsdrukken en het normale hartminuutvolume. Het blijkt dat de RPF (renale plasmastroom) sterk gerelateerd is an de $\mathrm{PaCO}_{2}$ en de $\mathrm{FEV}_{1}$. Het geheel 
suggereert renale vasoconstrictie met secundaire volumeretentie in aanwezigheid van een normale arteriële druk. De activatie van het RAAS zou een factor kunnen zijn die het verband tussen systemische en pulmonale bloeddruk verklaart; een verband dat onafhankelijk is van de wiggedruk. De hoogten van bloeddruk en $\mathrm{PaCO}_{2}$ blijken redelijk de aanwezigheid van pulmonale hypertensie te voorspellen. Met betrekking tot de neurohumorale invloeden, blijken de gemengd-veneuze adrenaline- en noradrenaline-spiegels gecorreleerd aan de $\mathrm{PaO}_{2}$ en $\mathrm{PaCO}_{2}$.

In hoofdstuk 5 worden in navolging van eerdere literatuurgegevens, de aanvullende effecten van nifedipine tijdens normoxie op de circulatie bestudeerd. Het blijkt dat nifedipine in combinatie met zuurstof vooral arteriële vasodilatatie veroorzaakt, zonder dat de gaswaarden duidelijk beïnvloed worden. Bovendien blijkt er een tendens tot verslechtering van de shuntfractie bij patiënten met pulmonale hypertensie in vergelijking tot degenen met een normale MPAP.

In hoofdstuk 6 worden de effecten van nifedipine en lage-dosis-captopril met elkaar vergeleken. In tegenstelling tot de systemische vasodilatatie onder invloed van nifedipine, oefent de ACE-remmer weinig invloed uit op de bloeddruk en het hartminuutvolume, doch vertonen de mPAP en shuntfractie een tendens tot daling. Dit gunstig effect zou kunnen berusten op veneuze vasodilatatie en/of lokale weefselinhibitie van het RAAS, in afwezigheid van systemische effecten.

Hoofdstuk 7 beschrijft de overleving van de patiënten die inmiddels binnen het protocol onderzocht zijn. De resultaten blijken overeen te stemmen met de overlevingsgegevens uit bekende zuurstofstudies. In de Cox-regressieanalyse blijken de gemengd-veneuze zuurstofspanning en -saturatie de belangrijkste voorspellers ten aanzien van de overleving. Indien deze waarden representatief geacht worden voor de weefselsaturatie, sluiten deze bevindingen aan bij de gedachte dat zowel oxygenatie op zich als het zuurstoftransport in het lichaam de prognose bepalen. De bevinding dat een hartfrequentie $<90$ slagen.min ${ }^{-1}$ en een systemisch zurstoftransport $>1200 \mathrm{ml} \cdot \mathrm{min}^{-1}$ een gunstige invloed hebben, past in deze hypothese.

Hoofdstuk 8 gaat verder in op de resultaten. De basale gegevens, met name de verbanden tussen de $\mathrm{PaCO}_{2}$ en de $\mathrm{FEV}_{1}$ enerzijds en de RPF anderzijds, in combinatie met de hoge reninespiegels, geven de nier een centrale rol in de pathofysiologie van de oedeemvorming 
bij het cor pulmonale. De vaststelling van de relatie tussen arterièle en pulmonale bloeddruk opent een nieuw veld van onderzoekingen met betrekking tot de invloed van de longen op vaatwandfactoren en endotheel.

Het onderzoek met bijwoorbeeld ACE-remmers vestigt de aandacht op de rol van het veneuze vaatbed. 


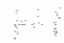

$\therefore \quad \div \quad \vdots \quad$ 


\section{Summary}

In this thesis the mechanisms, involved in the pathophysiology of cor pulmonale secondary to chronic obstructive pulmonary disease (COPD), are discussed. Taking into account the results of previous studies, with emphasis on chronic hypoxia and right ventricular function, additional investigations have been performed.

Chapter 1 summarizes the tools, used in the clinical studies. During normoxia, patients underwent right heart catheterisation. At the same time neuro-endocrine variables were measured (catecholamines, renin and angiotensine II). In the analysis of the basal data, special attention was given to frequently used variables such as lung function, bloodgases (especially the $\mathrm{PaCO}_{2}$ ) and the mean arterial pressure.

In chapter 2 the data in the literature on pulmonary hypertension and cor pulmonale, secondary to obstructive lung disease are described. It is noted that chronic hypoxia and hypercapnia are associated with a marked tendency to retain salt and water. The adrenergic system might be involved in the pathogenesis of the pulmonary and systemic hypertension, as for instance demonstrated in sleep-apnea studies.

Right heart catheterisation is still the major diagnostic manoeuvre. As to the therapeutic options of the hypoxic cor pulmonale, Iong-term oxygen therapy is the first choice. The routine use of diuretics, digitalis and vasodilating agents cannot be recommended.

In chapter 3 the methodology and criteria for patient selection are discussed.

Chapter 4 summarizes the basal data. Various correlations strongly suggest a major role for the lungs with respect to the regulation of the systemic and the renal circulation. For instance, the renal plama flow (RPF) is correlated with both the $\mathrm{PaCO}_{2}$ and the $\mathrm{FEV}_{1}$. Renin and bicarbonate values were markedly elevated, considering the normal levels of wedge pressure and cardiac output. These data suggest renal vasoconstriction and salt retention independently of the quality of the systemic circulation. Activation of the renin-angiotensin system could be the link here, explaining the concomitant appearance of both pulmonary and systemic hypertension in advanced COPD. It was found that the $\mathrm{MAP}$ and $\mathrm{PaCO}_{2}$ both predict the presence of pulmonary hypertension. The importance of the adrenergic system 
in the regulation of the pulmonary vascular tone comes from the observation that $\mathrm{PaO}_{2}$ en $\mathrm{PaCO}_{2}$ were correlated with mixed-venous epinephrine and norepinephrine values.

In chapter 5 the effects of oral nifedipine, additive to low-flow oxygen are presented. Nifedipine merely causes systemic vasodilation and even adverse effects with respect to gastensions. Moreover, in the subgroup analysis, it was shown that in patients with proven pulmonary hypertension nifedipine lowers $\mathrm{PaO}_{2}$ by an increase in shunt fraction.

The effects of nifedipine are compared to those of captopril in chapter 6. Captopril acts differentlly from nifedipine, in that it tends to reduce the MPAP and the shunt fraction in the absence of systemic effects. It is stated that this beneficial influence depends on venous vasodilation rather than arterial vasodilation.

Overall survival data are presented in chapter 7. Using the Cox-regression analysis it appears that mixed venous oxygen tension and saturation are the major determinants of survival during long term therapy, as it is also evidenced by the prognostic significance of the systemic oxygen transport and heart rate.

Chapter 8, finally discusses in a general way the topics of the previous chapters. Renal involvement in oedema formation underlines the "pulmonary-renal axis" in COPD. Further studies are suggested to evaluate the role of endothelin and other factors, such as EDRF, in the pathogenesis of systemic and pulmonary hypertension in advanced COPD. 


\section{Dankwoord}

Het verrichten van klinisch wetenschappelijk onderzoek is een proces waarbij velen, dikwijls afkomstig uit verschillende disciplines, betrokken zijn. Zo is het met dit proefschrift ook gegaan.

De eerste opleidingsjaren te Dordrecht, waaraan goede herinneringen bewaard worden, werden gevolgd door de periode in het Zuiderziekenhuis. Inspiratie tot onderzoek werd verkregen op de donderdagavond vergaderingen van de metabolic ward club, een groep van in circulatie geinteresseerden, onder leiding van Dr. P.W. de Leeuw.

Beste Peter, inmiddels hooggeleerd, ik ben je zeer erkentelijk voor de plezierige wijze waarop je de totstandkoming van dit proefschrift hebt begeleid. Tijdens de bewerking van de gegevens heb ik mogen profiteren van jouw bijzondere kennis en pathofysiologisch inzicht, tevens van de gastvrijheid in jullie huis.

Professor Birkenhäger, ik heb het zeer gewaardeerd dat $\mathrm{u}$, als initiator van het Rotterdamse circulatieonderzoek, zoveel waardevolle adviezen hebt gegeven bij de definitieve vormgeving van het manuscript.

Bij de uitvoering van het onderzoek was de hulp van de leden van de metabolic ward centrale, te weten Paul van Es, Marianne Looman, Hermien de Bruijn, Pau Tchang en Rene de Bos, van groot belang. Zonder de anderen te kort te doen, dank ik Paul voor de goede samenwerking bij het soms tijdrovende patientgebonden onderzoek.

De collegae Heysteeg en Slingerland, longartsen in het Zuiderziekenhuis, waren behulpzaarn bij de selectie van de patienten. Met betrekking tot de analyse wan de overleving werden gegevens verstrekt door de afdeling bevolking van de gemeente Rotterdam en enkele huisartsen.

Jacqueline Dito en Willem van Smaalen hebben veel tijd besteed aan het manuscript. De uiteindelijke vormgeving was bij jullie in professionele handen; Hartelijk dank.

De vele grafieken werdlen, een traditie waardig, op deskundige wijze verzorgd door Carl Hubers van Assenraad. De collegae en de secretaresses van de maatschap Interne 
Geneeskunde in het Ikazia Ziekenhuis ben ik erkentelijk voor hun steun in de afgelopen maanden.

Nettie, ik ben je erg dankbaar voor de ruimte en tijd, die je de afgelopen jaren in ons gezin wist te creeeren. Of de woorden wan de vorige eeuwse dichter Werumeus Buning bewaarheid zullen worden, valt echter te betwijfelen: "Het geluk wan menig burgerman is de wrede van het huisgezin en wan de kinderen die mee aan tafel eten". 


\section{Curriculum vitae}

Adriaan Dees werd geboren op 16 februari 1957 te Terneuzen en bezocht het Zeldenrustcollege (Atheneum B) in dezelfde plaats. Hij studeerde medicijnen aan de Rijksuniversiteit Gent (1976-1979) en de Erasmus Universiteit te Rotterdam (1979-1983). Van 1981 tot 1983 was hij als docent medische vakken verbonden aan het Van 't Hoffinstituut te Rotterdam.

$\mathrm{Na}$ een korte periode als wachtassistent te hebben gewerkt in de Oosterscheldeziekenhuizen te Goes begon hij de opleiding tot internist. Van 1983 tot 1985 was hij werkzaam op de afdeling inwendige geneeskunde van het Diaconessenhuis Refaja te Dordrecht (opleiders $C$. Verdoorn才, Dr. B.P. Hazenberg). Van 1985 tot 1988 continueerde hij de opleiding in het Zuiderziekenhuis te Rotterdam (opleiders Prof. Dr. W.H. Birkenhäger, Dr. P.W. de Leeuw).

De registratie tot internist vond plaats in september 1988; aansluitend was hij werkzaam op de afdeling interne oncologie (hoofd: Dr. G. Stoter) van de Dr. Daniel den Hoed Kliniek, met als aandachtsgebieden de intensive care en de gastro-enterologie. Sedert oktober 1990 is hij als algemeen internist verbonden aan het Ikazia Ziekenhuis te Rotterdam. 


\section{Publicaties}

Dees A., Verweij J., van Putten W.L.J., Stoter G. Mitomycin-C is an inactive drug in the third line treatment of hormone and chemotherapy refractory breast cancer. Eur J Clin Oncol 1987; 23: 1343-1347.

Dees A., Blok W.L., de Leeuw P.W. Bloeddrukverlaging, een koud kunstje? Ned Tijdschr Geneeskd 1989; 133: 1625-1626.

Dees A., Goey S.H., Stoter G. Cardiopulmonale bijwerkingen van een nieuwe kankertherapie. Int Care Rev 1990; 5: 85-87.

Dees A., Kluchert S.A., van Vliet A.C.M. Pseudorenal failure associated with internal urine leakage. Neth J Med 1990; 37: 197-201.

Dees A., Batenburg P.L., Umar H.M., Menon R.S., Verweij J. Strongyloides stercoralis associated with a bleeding gastric ulcer. Gut 1990; 31: 1414-1415.

Dees A, Ligthart J., Planting A.S.Th., van Putten W.L.J., Stoter G. Mechanical ventilation in cancer patients. Analysis of clinical data and outcome. Neth I Med 1990; 37: 183-188.

Dees A., Schonfeld D.H.W., Roodenburg C.J., Vecht Ch.J. Cerebral emboli in chronic intravascular coagulation detected by Single Photon Emission Tomography (SPECT). Ann Oncol 1990; 1: 304-305.

Dees A., Hoff A.M., Mali S.P., Hordijk M.L. Wanneer latex loslaat ofwel een mechanisch ulcus pylori. Ned Tijdschr Geneeskd 1990; 134: 2011.2013.

Dees A., Heysteeg M., de Leeuw P.W. Pulmonale hyperiensie en cor pulmonale veroorzaakt door chronische obstructieve longaandoening; pathogenese en behandeling. Ned Tijdschr Geneeskd 1991; 135: 1120-1124.

Dees A., Batenburg de Jong R.J., Meeuwis C.A., de Boer M.F., de Leeuw P.W. Carotid sinus syndrome after carotid artery surgery. Postgrad Med J (ter publicatie).

Dees A., van Es P.N., Heysteeg M., de Leeuw P.W. Haemodynamics and gasexchange, irrespective of hypoxia, in severe abstructive pulmonary disease. (In: Jezeck V., Morpurgo M., Tramarin R. eds. Right ventricular hypertrophy and function in chronic lung disease. Basel: Springer-Verlag) (ter publicatie). 